\title{
EXPRESSÃO DE PCNA, E-CADERINA E $\beta$-CATENINA EM CARCINOMAS ESPINOCELULARES E ESCAMOSO BASALÓIDE DE BOCA: CORRELAÇÃO COM O COMPORTAMENTO CLÍNICO E PROGNÓSTICO
}

\author{
JOÃO ADOLFO COSTA HANEMANN
}

Tese apresentada à Faculdade de Odontologia de Bauru, Universidade de São Paulo, como parte dos requisitos para obtenção do título de Doutor em Odontologia, área de Patologia Bucal.

(Edição Revisada)

BAURU 


\title{
EXPRESSÃO DE PCNA, E-CADERINA E $\beta$-CATENINA EM CARCINOMAS ESPINOCELULARES E ESCAMOSO BASALÓIDE DE BOCA: CORRELAÇÃO COM O COMPORTAMENTO CLÍNICO E PROGNÓSTICO
}

\author{
JOÃO ADOLFO COSTA HANEMANN
}

Tese apresentada à Faculdade de Odontologia de Bauru, Universidade de São Paulo, como parte dos requisitos para obtenção do título de Doutor em Odontologia, área de Patologia Bucal.

Orientadora: Prof. ${ }^{a}$ Dr. ${ }^{a}$ Denise Tostes Oliveira

(Edição Revisada)

BAURU 


\begin{tabular}{|c|c|}
\hline \multirow{5}{*}{ H193e } & Hanemann, João Adolfo Costa \\
\hline & $\begin{array}{l}\text { Expressão de PCNA, E-caderina e } \beta \text {-catenina em carcinomas espinocelulares } \\
\text { e escamoso basalóide de boca: correlação com o comportamento clínico e } \\
\text { prognóstico.--Bauru, } 2004 \text {. }\end{array}$ \\
\hline & xxii, 132p.: il.; $30 \mathrm{~cm}$. \\
\hline & $\begin{array}{l}\text { Tese. (Doutorado)--Faculdade de Odontologia de Bauru. Universidade de São } \\
\text { Paulo. }\end{array}$ \\
\hline & Orientadora: Prof. ${ }^{\mathrm{a}}$ Dr. ${ }^{\mathrm{a}}$ Denise Tostes Oliveira \\
\hline
\end{tabular}

Autorizo, exclusivamente para fins acadêmico e científico, a reprodução total ou parcial desta tese por processos fotocopiadores e/ ou meios eletrônicos.

Assinatura do autor:

Data: Bauru, 02 de junho de 2004.

Projeto de pesquisa aprovado pela Comissão de Ética em Pesquisa do Hospital do Câncer AC Camargo- número 497/03, em reunião de 29 de abril de 2003. 


\section{JOÃO ADOLFO COSTA HANEMANN}

22 de junho de 1972

Nascimento

Alfenas/MG

Filiação

David Pedro Hanemann

Dinalva Costa Hanemann

1990-1993

Curso de Graduação em Odontologia pela Escola de Farmácia e Odontologia de Alfenas

1996-1997

Curso de Especialização em Estomatologia pela Pontifícia Universidade Católica de Minas Gerais

1997-1999

Mestrado em Estomatologia na Faculdade Federal de Odontologia de Diamantina

2000-2001

Professor Substituto de Semiologia na Escola de Farmácia e Odontologia de Alfenas

2002-2004

Doutorado em Patologia Bucal na Faculdade de Odontologia de Bauru-Universidade de São Paulo

2004

Professor Assistente I de Estomatologia na Escola de Farmácia e Odontologia de Alfenas

Associações

SOBE- Sociedade Brasileira de Estomatologia

SOME- Sociedade Mineira de Estomatologia

SBPqO- Sociedade Brasileira de Pesquisa Odontológica 
“Bem-aventurado aquele que tem o Deus de Jacó por seu auxílio, cuja esperança está no Senhor, seu Deus, que fez os céus, a terra, o mar e tudo o que neles há e mantem para sempre a sua fidelidade".

Salmo 126: 5-6. 


\section{DEDICATÓRIA}

Aos meus pais David (in memoriam) e Dinalva.

A semente que um dia plantaram germinou, desenvolveu-se

e hoje produz mais um fruto.

A vocês, minha eterna gratidão! 
À minha orientadora Prof. ${ }^{a}$ Dr. $^{a}$ Denise Tostes Oliveira, agradeço não apenas pela orientação segura e criteriosa na elaboração deste trabalho mas também por todos os ensinamentos transmitidos durante este período de convivência e, principalmente, pelo constante apoio e incentivo à minha carreira acadêmica assim como pela amizade cultivada.

Minha sincera gratidão! 
Ao Dr. Gilles Landman, meu co-orientador, sou grato pelos comentários, críticas e sugestões sempre oportunas quando do desenvolvimento deste trabalho.

Ao Prof. Dr. Luiz Paulo Kowalski minha admiração pelo exímio cirurgião e notável pesquisador que é. Agradeço também pela possibilidade de realização deste trabalho e pela atenção, presteza e disposição a mim sempre dispensadas. 
Ao Prof. Dr. Alberto Consolaro, coordenador dos Cursos de PósGraduação em Patologia Bucal da Faculdade de Odontologia de Bauru-USP, agradeço a oportunidade de cursar este doutorado nesta nobre "casa" e também a disponibilidade financeira para aquisição dos anticorpos utilizados neste trabalho. Minha grande admiração pelo dedicado mestre que tem sido até aqui. 


\section{AGRADECIMENTOS ESPECIAIS}

A Deus, pois sem Ele nada do que foi feito se faria. Ao Senhor dedico toda honra, glória e gratidão.

Às minhas irmãs Sônia e Elza e aos meus sobrinhos Leonardo, Leonora, Sophia e Sarah que, com os seus auxílios e contribuições, permitiram a realização deste curso de doutorado.

À Tia Elza, que sempre apoiou os meus sonhos e ideais e muito me tem ajudado.

Aे Simone, que soube entender todos estes momentos em que estive distante e que me tem feito acreditar que "amar vale a pena". 


\section{AGRADECIMENTOS}

Aos professores da Disciplina de Patologia Bucal da Faculdade de Odontologia de Bauru Prof. Dr. Alberto Consolaro, Prof..$^{a}$ Dr. ${ }^{a}$ Denise Tostes Oliveira, Prof..$^{a}$ Dr. ${ }^{a}$ Vanessa Soares Lara e, em especial, ao Prof. Dr. Luís Antônio de Assis Taveira pelo carinho, amizade e desprendimento com que sempre me atendeu e pelos momentos alegres que passamos juntos.

Aos funcionários da Disciplina de Patologia Bucal da Faculdade de Odontologia de Bauru Cristina, Fatiminha, Bernadete e Valdir por tudo que fizeram por mim, vocês estarão sempre em meu coração.

Às minhas colegas de turma Aline, Andrea, Maria Fernanda, Maria Renata e Tânia por todos os momentos desfrutados juntos.

Aos demais pós-graduandos da Patologia Bucal da FOB-USP Carol, Rosário, Valdomiro, Lídia, Rosa, Bethânia, Camila, Lidiane, Luciana, Renata Consolaro, Renata Falchete, Renato, Tiago, Erick, Leda, Marta, Patrícia e Suzana por todas as experiências vivenciadas.

Ao Prof. Dr. Alessandro Antônio Costa Pereira por ter incentivado e auxiliado a minha vinda para Bauru cursar o doutorado e também por ter suprido minha ausência na Escola de Farmácia e Odontologia de Alfenas-Centro Universitário Federal, além da grande amizade. 
À $\mathcal{D r} .^{a}$ Fernanda Costa Grizzo de Sampaio Góes por ter me dado orientações seguras em momentos de incertezas e pelo auxílio indispensável na realização deste trabalho.

À Prof.a ${ }^{\text {Dr.a }}{ }^{a}$ Inês $\mathcal{N}$ obuķo Nishimoto pela realização e orientação da estatística deste trabalho.

À química e farmacêutica Suefy Nonogaki, do Laboratório de Imuno-histoquímica do Instituto Ludwig de Pesquisa sobre o Câncer, pela segura orientação nas reações imunohistoquímicas e pelas sugestões apresentadas.

Ao Prof. Valdir João Afonso pela correção do vernáculo.

À bibliotecária Maria Helena Ronchesel pela correção e normatização técnica deste trabalho.

À doutoranda Marta Miyazawa pela elaboração do abstract e amizade.

A todos os funcionários da Biblioteca da Faculdade de Odontologia de Bauru, em nome de Cybelle de Assumpção Fontes, pelo auxílio e orientações no transcorrer do curso.

A todos os funcionários da Secretaria de Pós-graduação da Faculdade de Odontologia de Bauru, em especial a Giane Tenório Quintela, pela prontidão com que sempre me atenderam.

Aos médicos e demais funcionários do Departamento de Cirurgia de Cabeça e Pescoço Otorrinolaringologia do Hospital do Câncer AC Camargo, em especial ao Dr. José Magrine è Rita, pela atenção sempre dispensada. 
Aos funcionários do Laboratório de Anatomia Patológica do Hospital do Câncer AC Camargo César, Carlinhos, Severino e Miuki pela confecção dos cortes microscópicos.

A todos os funcionários do Serviço de Arquivo Médico do Hospital do Câncer AC Camargo, em especial a Sra. Hirde Contesini, pela disponibilidade e presteza com que sempre me atenderam.

A todos os funcionários do Restaurante Vniversitário da Faculdade de Odontologia de Bauru que, anonimamente, prepararam grande parte das minhas refeições em Bauru. Minha gratidão!

À Prof.a Michele Pereira da Disciplina de Patologia da Escola de Farmácia e Odontologia de Alfenas-Centro Universitário Federal pela amizade e incentivo.

Aos amigos Alex e Renato pela convivência amiga e apoio constante. Vocês são "amigos mais chegados que irmãos".

Aos irmãos da Igreja Presbiteriana de Bauru pelos momentos preciosos de comunhão desfrutados e pelo auxílio sempre dispensado. 


\section{AGRADECIMENTOS INSTITUCIONAIS}

À Direção da Faculdade de Odontologia de Bauru, Universidade de São Paulo, na pessoa da Diretora Prof. ${ }^{a}$ Dr. ${ }^{a}$ Maria Fidela de Lima Navarro.

À Comissão de Pós-graduação da Faculdade de Odontologia de Bauru, na pessoa do Presidente Prof. Dr. José Carlos Pereira.

Ao Coordenador dos Cursos de Pós-graduação em Patologia Bucal da Faculdade de Odontologia de Bauru Prof. Dr. Alberto Consolaro.

À Direção da Escola de Farmácia e Odontologia de Alfenas-Centro Universitário Federal, na pessoa do Diretor Prof. Maciro Manoel Pereira.

À CAPES, pelo auxílio pecuniário. 


\section{SUMÁRIO}

LISTA DE FIGURAS $\quad$ XV

LISTA DE TABELAS xvii

LISTA DE ABREVIATURAS E SÍMBOLOS Xix

RESUMO $\quad$ xxii

1 INTRODUÇÃO 1

2 REVISÃO DE LITERATURA 5

2.1 Carcinoma Escamoso Basalóide 6

2.2 Carcinoma Escamoso Basalóide X Carcinoma Espinocelular 13

2.3 Antígeno Nuclear de Proliferação Celular (PCNA) 19

2.4 Moléculas de Adesão Celular 22

3 PROPOSIÇÃO 39

$4 \quad$ MATERIAL E MÉTODOS 41

4.1 População de Estudo e Seleção da Amostra 42

4.2 Registro dos Dados Clínicos e Microscópicos 44

4.3 Análise Microscópica $\quad 45$

$4.4 \quad$ Variáveis de Estudo 46

4.5 Método Imuno-histoquímico 48

4.6 Avaliação Imuno-histoquímica 50

4.7 Análise Estatística $\quad 52$

$\begin{array}{lll}4.8 & \text { Registro Fotográfico } & 54\end{array}$

4.9 Questões Éticas $\quad 54$ 
5 RESULTADOS 55

5.1 Casuística 56

5.2 Caracterização Demográfica e Clínica da População de Estudo 57

5.3 Análise Morfológica dos Carcinomas $\quad 62$

5.3.1 Carcinoma Escamoso Basalóide $\quad 62$

$\begin{array}{lll}\text { 5.3.2 Carcinomas Espinocelulares } & 68\end{array}$

5.4 Análise Imuno-histoquímica dos Carcinomas 77

5.5 Análise de Sobrevida 92

6 DISCUSSÃO $\quad 98$

7 CONCLUSÕES 114

$\begin{array}{ll}\text { ANEXOS } & 118\end{array}$

REFERÊNCIAS BIBLIOGRÁFICAS $\quad 122$

$\begin{array}{ll}\text { ABSTRACT } & 131\end{array}$

APÊNDICES 


\section{LISTA DE FIGURAS}

FIGURA 1- CEB apresentando padrão sólido ou lobular com disjunção entre o epitélio tumoral e o tecido conjuntivo adjacente. Observar também hialinização do tecido conjuntivo adjacente (A e B). (HE, aumento original $\mathrm{A}$ e $\mathrm{B}=50 \mathrm{X}$ )

FIGURA 2- Disposição em paliçada das células periféricas das ilhotas tumorais no CEB. Observar a presença de inúmeras figuras de mitoses atípicas (A e $\mathrm{B})$. (HE, aumento original $\mathrm{A}=400 \mathrm{X}$ e $\mathrm{B}=1000 \mathrm{X}$ )

FIGURA 3- CEB apresentando espaços císticos PAS positivos além de estruturas ductiformes (A e B). (HE, aumento original $A=50 \mathrm{X}$ e $\mathrm{B}=400 \mathrm{X})$

FIGURA 4- CEB em continuidade com a mucosa bucal (A). Componente escamoso associado ao CEB apresentando áreas focais de queratinização (B). (HE, aumento original $\mathrm{A}=50 \mathrm{X}$ e $\mathrm{B}=100 \mathrm{X}$ )

FIGURA 5- CEC/BD apresentando uma alta queratinização tumoral e infiltração muscular (A). Em B, observar ausência de queratinização no CEC/PD. (HE, aumento original $\mathrm{A}=100 \mathrm{X}$ e $\mathrm{B}=400 \mathrm{X}$ )

FIGURA 6- CEC/PD apresentando intenso pleomorfismo nuclear, hipercromatismo e numerosas figuras de mitoses atípicas (A e B). (HE, aumento original A $\mathrm{e} B=1000 \mathrm{X})$

FIGURA 7- Padrão de invasão infiltrativo do $\mathrm{CEC/BD}$ com células neoplásicas dispostas em cordões grossos (A). Em B, padrão de invasão em cordões finos do $\mathrm{CEC} / \mathrm{PD}$ (HE, aumento original $\mathrm{A}=50 \mathrm{X}$ e $\mathrm{B}=100 \mathrm{X}$ )

FIGURA 8- Infiltração perineural pelo CEC/BD em A e pelo CEC/PD em B. (HE, aumento original $\mathrm{A}=100 \mathrm{X}$ e $\mathrm{B}=400 \mathrm{X}$ )

FIGURA 9- Imunopositividade ao PCNA das células epiteliais periféricas das ilhotas tumorais no $\mathrm{CEB}$ (IHQ, aumento original $\mathrm{A}=100 \mathrm{X}$ e $\mathrm{B}=400 \mathrm{X}$ )

FIGURA 10- Imunopositividade ao PCNA das células neoplásicas do CEC/BD (A e B), exceto nas pérolas córneas (B) e áreas focais de queratinização. (IHQ, aumento original $\mathrm{A}=50 \mathrm{X}$ e $\mathrm{B}=400 \mathrm{X}$ )

FIGURA 11- Imunopositividade à E-caderina na mucosa bucal normal (A). Em B, 
forte expressão membranosa da E-caderina no CEC/BD. (IHQ, aumento original $\mathrm{A}$ e $\mathrm{B}=400 \mathrm{X}$ )

FIGURA 12- Imunoexpressão da E-caderina no CEC/BD (A), exceto nas áreas de queratinização, e redução desta expressão no CEC/PD (B).(IHQ, aumento original $\mathrm{A}=50 \mathrm{X}$ e $\mathrm{B}=100 \mathrm{X})$

FIGURA 13- Imunoexpressão da E-caderina no CEB com padrão membranoso em A e redução significativa da expressão em $\mathrm{B}$. (IHQ, aumento original A e B= 400X)

FIGURA 14- Imunoexpressão com padrão membranoso da $\beta$-catenina no CEC/BD (A) e com padrão citoplasmático irregular no CEC/PD (B). (IHQ, aumento original $\mathrm{A}$ e $\mathrm{B}=400 \mathrm{X})$

FIGURA 15- Imunoexpressão da $\beta$-catenina nas células epiteliais neoplásicas do CEB. (IHQ, aumento original A e B= 400X)

FIGURA 16- Sobrevida global dos pacientes com carcinomas escamosos basalóides (CEB), carcinomas espinocelulares pouco diferenciados (CEC/PD) e carcinomas espinocelulares bem diferenciados (CEC/BD) de boca. Porcentagem de sobrevida acumulada pela técnica de Kaplan-Meier

FIGURA 17- Sobrevida livre de doença dos pacientes com carcinomas escamosos basalóides (CEB), carcinomas espinocelulares pouco diferenciados (CEC/PD) e carcinomas espinocelulares bem diferenciados (CEC/BD) de boca. Porcentagem de sobrevida acumulada pela técnica de KaplanMeier 


\section{LISTA DE TABELAS}

TABELA 1- Sistema de graduação do front de invasão tumoral de BRYNE et al. ${ }^{21} \quad 46$

TABELA 2- Distribuição dos carcinomas escamosos basalóides, carcinomas espinocelulares pouco diferenciados e carcinomas espinocelulares bem a moderadamente diferenciados de boca, quanto aos critérios de inclusão estabelecidos. Hospital do Câncer, São Paulo, 1970 a 2000

TABELA 3- Distribuição das características demográficas e da história clínica dos pacientes com carcinoma escamoso basalóide, com carcinoma espinocelular pouco diferenciado e com carcinoma espinocelular bem a moderadamente diferenciado de boca. Hospital do Câncer, São Paulo, 1970 a 2000

TABELA 4- Distribuição das características clínicas dos pacientes com carcinoma escamoso basalóide, com carcinoma espinocelular pouco diferenciado e com carcinoma espinocelular bem a moderadamente diferenciado de boca. Hospital do Câncer, São Paulo, 1970 a 2000

TABELA 5- Distribuição das características clínicas dos pacientes com carcinoma escamoso basalóide, com carcinoma espinocelular pouco diferenciado e com carcinoma espinocelular bem a moderadamente diferenciado de boca. Hospital do Câncer, São Paulo, 1970 a 2000

TABELA 6- Distribuição das características morfológicas do carcinoma escamoso basalóide. Hospital do Câncer, São Paulo, 1970 a 2000

TABELA 7- Distribuição das características morfológicas do carcinoma espinocelular pouco diferenciado e do carcinoma espinocelular bem a moderadamente diferenciado. Hospital do Câncer, São Paulo, 1970 a 2000

TABELA 8- Distribuição das infiltrações tumorais do carcinoma escamoso basalóide, do carcinoma espinocelular pouco diferenciado e do carcinoma espinocelular bem a moderadamente diferenciado de boca. Hospital do Câncer, São Paulo, 1970 a 2000

TABELA 9- Distribuição imuno-histoquímica dos anticorpos PCNA, E-caderina e $\beta$ catenina nos carcinomas escamosos basalóides, nos carcinomas 
espinocelulares pouco diferenciados e bem a moderadamente diferenciados de boca. Hospital do Câncer, São Paulo, 1970 a 2000

TABELA 10- Distribuição do PCNA em relação às características clínicas dos três grupos de carcinomas de boca. Hospital do Câncer, São Paulo, 1970 a 2000

TABELA 11- Distribuição do PCNA em relação às características microscópicas dos três grupos de carcinomas de boca. Hospital do Câncer, São Paulo, 1970 a 2000

TABELA 12- Distribuição de E-caderina e $\beta$-catenina em relação às características clínicas dos três grupos de carcinomas de boca. Hospital do Câncer, São Paulo, 1970 a 2000

TABELA 13- Distribuição de E-caderina e $\beta$-catenina em relação às características microscópicas dos três grupos de carcinomas de boca. Hospital do Câncer, São Paulo, 1970 a 2000

TABELA 14- Distribuição de PCNA, E-caderina e $\beta$-catenina em relação ao comprometimento linfonodal confirmado microscopicamente dos três grupos de carcinomas de boca. Hospital do Câncer, São Paulo, 1970 a 2000

TABELA 15- Análise de sobrevida global dos pacientes com carcinomas de boca. Probabilidade de sobrevida acumulada pela técnica de Kaplan-Meier

TABELA 16- Análise de sobrevida livre de doença dos pacientes com carcinomas de boca. Probabilidade de sobrevida acumulada pela técnica de KaplanMeier 


\section{LISTA DE ABREVIATURAS E SÍMBOLOS}

$\alpha:$ alfa

$\beta$ : beta

$\gamma$ : gama

$\mu \mathrm{m}$ : micrometro

000: vivo livre de doença

${ }^{\circ} \mathrm{C}$ : grau centígrado

$\left[{ }^{18} \mathrm{~F}\right] \mathrm{FDG}:\left[{ }^{18} \mathrm{~F}\right]$-2-fluorodeoxyglucose

AC: Antônio Cândido

AgNORs: argyrophilic nuclear organizer regions

Bax: Bcl-2 homologous antagonist

B-caderina: caderina cerebral

Bcl-2: B-cell lymphoma-2

Bcl-X: Bcl-2 homologous-X

BSA: bovine serum albumine

Ca: carcinoma

CAM: cell adhesion molecule

CEB: carcinoma escamoso basalóide

CEC: carcinoma espinocelular

CEC/BD: carcinoma espinocelular bem a moderadamente diferenciado

$\mathrm{CEC} / \mathrm{PD}$ : carcinoma espinocelular pouco diferenciado

CEP: comissão de ética em pesquisa

DAB: diaminobenzidine tetrahydrochloride

DMSO: dimetilsulfóxido

DNA: deoxyribonucleic acid

EBV: Epstein-Barr virus

E-caderina: caderina epitelial

EGF: epidermal growth factor

EGFR: epidermal growth factor receptor

$\mathrm{H}_{2} \mathrm{O}_{2}$ : peróxido de hidrogênio 
HE: hematoxilina e eosina

HPV: human papilloma virus

IHQ: imuno-histoquímica

kDa: kilodalton

Ki-67: Kiel $67^{\text {a. }}$ Culture dishe, monoclonal antibody which recognizes a labille epitope on a nuclear antigen in cyclin cells

L-CAM: caderina do fígado de galinha

MIB-1: Ki-67 analogous monoclonal antibody

mL: mililitro

mM: milimol

MOASS: morte sem evidência de recidiva do tumor primário

MOCA: morte decorrente do tumor primário

MOCI: morte por intercorrência cirúrgica

mRNA: messenger ribonucleic acid

$\mathrm{N}+$ : presença de metástase em linfonodos regionais

N0: ausência de metástase em linfonodos regionais

N1: metástase em um único linfonodo homolateral, com $3 \mathrm{~cm}$ ou menos em seu maior diâmetro, segundo a classificação TNM para tumores malignos de boca

N2: metástase em um único linfonodo homolateral, com mais de $3 \mathrm{~cm}$ ou até $6 \mathrm{~cm}$ em seu maior diâmetro, ou em linfonodos homolaterais múltiplos, nenhum deles com mais de $6 \mathrm{~cm}$ em seu maior diâmetro, ou em linfonodos bilaterais ou contralaterais, nenhum deles com mais de $6 \mathrm{~cm}$ em seu maior diâmetro, segundo a classificação TNM para tumores malignos de boca

N3: metástase em linfonodo regional com mais de $6 \mathrm{~cm}$ em seu maior diâmetro, segundo a classificação TNM para tumores malignos de boca

N-caderina: caderina neural

OMS: Organização Mundial da Saúde

p53: a $53 \mathrm{kDa}$ protein

PAS: periodic acid Schiff

PBS: phosphate buffered saline

P-caderina: caderina placentária

PCNA: proliferating cell nuclear antigen 
PET: positron emission tomography

$\mathrm{pH}$ : hydrogen ion concentration

$\mathrm{pN}+$ : presença de metástase em linfonodos regionais confirmada microscopicamente

SAME: serviço de arquivo médico

StreptABComplex: streptavidin and biotinylated peroxidase complex

T1: tumor com até $2 \mathrm{~cm}$ em sua maior extensão, segundo a classificação TNM para tumores malignos de boca

T2: tumor com mais de $2 \mathrm{~cm}$ e até $4 \mathrm{~cm}$ em sua maior extensão, segundo a classificação TNM para tumores malignos de boca

T3: tumor com mais de $4 \mathrm{~cm}$ em sua maior extensão, segundo a classificação TNM para tumores malignos de boca

T4: tumor com mais de 4cm em sua maior extensão, invadindo estruturas adjacentes, segundo a classificação TNM para tumores malignos de boca

TNM: classificação dos tumores malignos

UICC: União Internacional Contra o Câncer 


\section{RESUMO}

O carcinoma escamoso basalóide (CEB), uma variante agressiva distinta do carcinoma espinocelular (CEC), apresenta predileção para a região de cabeça e pescoço, especialmente base de língua. Um total de 17 CEBs localizados exclusivamente em boca, diagnosticados e tratados no período de 1970 a 2000 no Departamento de Cirurgia de Cabeça e Pescoço e Otorrinolaringologia do Hospital do Câncer AC Camargo, foram comparados a 26 CECs pouco diferenciados (CEC/PD) e a $28 \mathrm{CECs}$ bem a moderadamente diferenciados (CEC/BD) com estadiamento e localização equivalentes. Foram avaliadas algumas características clínicas como gênero, idade, raça, tabagismo, etilismo, localização do tumor primário, classificação pelo sistema TNM, tratamento, ocorrência de recidiva tumoral, metástases em linfonodos regionais, a distância e de segundo tumor primário. Além disso, outros aspectos biológicos como a expressão de PCNA e das moléculas de adesão celular E-caderina e $\beta$ catenina também foram comparativamente analisados. As probabilidades de sobrevida global e livre de doença foram calculadas pelo método de Kaplan-Meier e a influência das variáveis clínicas e microscópicas no prognóstico avaliada pelo modelo de regressão de Cox. Não se observou diferença estatisticamente significativa na expressão do PCNA entre os três grupos estudados. Para os grupos CEC/PD e CEB, a redução ou ausência da expressão de E-caderina foi observada em mais de $80,0 \%$ dos carcinomas sendo estatisticamente significativa quando comparada ao $\mathrm{CEC} / \mathrm{BD}(\mathrm{p}=0,019)$. A forte expressão tumoral da $\beta$-catenina foi visualizada, respectivamente, em 26,9\% e em 20,8\% dos CEC/BDs e CEC/PDs e em 41,2\% dos CEBs. Os marcadores imuno-histoquímicos PCNA, E-caderina e $\beta$-catenina não constituíram fatores de prognóstico para os pacientes com $\mathrm{CEB}, \mathrm{CEC} / \mathrm{PD}$ e $\mathrm{CEC} / \mathrm{BD}$, sendo as probabilidades de sobrevida global e livre de doença acumuladas em 5 e 10 anos semelhantes para os três grupos avaliados. A presença de metástase em linfonodo regional $(\mathrm{N}+)$ foi fator de prognóstico independente para os pacientes com CEB, CEC/PD e CEC/BD. Portanto, baseado nestes resultados, podemos concluir que o comportamento clínico e biológico do carcinoma escamoso basalóide e dos carcinomas espinocelulares bem, moderadamente e pouco diferenciados localizados na boca são semelhantes, não sendo influenciados pelo grau de diferenciação celular e/ou pela variante microscópica quando estas neoplasias apresentam estadiamentos clínicos avançados. 
1 INTRODUÇÃO 


\section{INTRODUÇÃO}

O carcinoma de células escamosas basalóide é considerado uma variante distinta do carcinoma espinocelular, inicialmente identificado e meticulosamente descrito na região de cabeça e pescoço por WAIN et al. ${ }^{82}$, em 1986. Esta neoplasia maligna apresenta uma marcante predileção para o trato aereodigestivo superior, embora possa estar presente em outros locais como pulmão, esôfago, canal anal e colo uterino ${ }^{6,61}$. Na boca, estes tumores têm sido descritos em soalho bucal ${ }^{1,23,28,37,43}$, língua ${ }^{43}$, mucosa jugal ${ }^{26}$, gengiva inferior ${ }^{2,43}$, túber de maxila ${ }^{80,85}$, trígono retromolar ${ }^{6}$, palato mole e orofaringe ${ }^{6}$.

Na região de cabeça e pescoço, embora a maior agressividade do CEB seja baseada principalmente em um comportamento clínico com recorrências locais freqüentes, além de metástases regionais e distantes ${ }^{37}$, alguns estudos compararam a evolução clínica e/ou biológica desta neoplasia maligna e do carcinoma espinocelular convencional ${ }^{2,27,28,44,49,60,90}$.

Para autores como ABIKO et al. ${ }^{2}$, COLETTA et al. $^{27}$, COPPOLA et al. ${ }^{28}$ e WINZENBURG et al. ${ }^{90}$, os pacientes com CEB apresentam uma evolução clínica desfavorável e um pior prognóstico quando comparados àqueles com CEC. Entretanto, outros autores $^{32,44,49,60}$ afirmam que ambas as neoplasias possuem um comportamento e uma evolução clínica similares.

Recentemente, GÓES et al. ${ }^{33}$ compararam 17 CEBs, 27 CECs bem a moderadamente diferenciados e 27 CECs pouco diferenciados localizados exclusivamente na mucosa bucal (língua, assoalho de boca, gengiva inferior e área retromolar), com base nas características clínicas incluindo idade, raça, história clínica de tabaco e álcool, localização tumoral, 
estadiamento TNM-UICC ${ }^{77}$, tratamento cirúrgico (radioterapia pós-operatória e quimioterapia adjuvante), recorrência local, regional, metástase a distância, segundo tumor primário e seguimento clínico do paciente. Os autores verificaram que não houve diferença estatisticamente significativa nas sobrevidas global, específica e livre de doença entre os três grupos de carcinomas e concluíram que o comportamento clínico bem como o prognóstico dos pacientes com CEB e CEC em boca são semelhantes quando os mesmos são pareados por localização tumoral, estadiamento clínico e tratamento.

O delineamento do comportamento biológico agressivo dos carcinomas espinocelulares da região de cabeça e pescoço tem sido baseado não somente na avaliação dos aspectos clínicos mas principalmente no potencial de proliferação celular e invasão tecidual, bem como na perda da expressão das moléculas de adesão das células epiteliais neoplásicas.

Carcinomas espinocelulares com altos índices de proliferação celular, determinados pela marcação imuno-histoquímica de $\mathrm{PCNA}^{3}, \mathrm{Ki}-67$ e $\mathrm{AgNOR}^{91}, \mathrm{Ki}^{-67 / M I B-1}{ }^{70}$ e ciclina D1 e Ki- $67^{81}$, apresentam geralmente um pior prognóstico com menores índices de sobrevida para os pacientes. Entretanto, esta correlação nem sempre pode ser estabelecida ${ }^{32,41,69,74}$.

Além dos índices de proliferação das células epiteliais neoplásicas, as alterações nas moléculas de adesão celular nos carcinomas espinocelulares, principalmente aquelas associadas ao complexo caderina-catenina ${ }^{16,36,71,88}$, são requisitos fundamentais para o processo de metástase, determinando um comportamento biológico mais agressivo e uma evolução clínica desfavorável para estes tumores ${ }^{25,51,89}$.

Inúmeros estudos ${ }^{11,25,31,46,62,67,76,89,92}$ avaliaram a relação entre a expressão imunohistoquímica de E-caderina e/ou de $\beta$-catenina em CECs na região de cabeça e pescoço e a presença de metástases em linfonodos. Embora a redução ou ausência da expressão destas 
moléculas de adesão celular tenha sido correlacionada com metastáses regionais ${ }^{25,46,76,94}$, outros autores não conseguiram confirmar estes resultados ${ }^{7,11}$.

A influência da expressão alterada das moléculas de adesão em CECs convencionais, com diferentes graus de diferenciação celular, no comportamento clínico tumoral são aspectos freqüentemente investigados ${ }^{7,11,17,25,31,46,47,48,51,59,62,67,76,89,92,94}$, todavia não foram encontrados relatos na literatura avaliando a expressão imuno-histoquímica de E-caderina e $\beta$-catenina em carcinomas escamosos basalóides localizados na cavidade bucal.

Portanto, o objetivo deste trabalho consiste na comparação das características clínicas, dos aspectos biológicos baseados na proliferação celular e na expressão das moléculas de adesão intercelular bem como na avaliação do prognóstico dos pacientes com carcinomas escamosos basalóides e carcinomas espinocelulares bem, moderadamente e pouco diferenciados localizados exclusivamente em boca. 
2 REVISÃO DE LITERATURA 


\section{REVISÃO DE LITERATURA}

\subsection{Carcinoma Escamoso Basalóide}

A neoplasia maligna mais comum da cavidade bucal é o carcinoma espinocelular, representando aproximadamente $95 \%$ de todas as neoplasias malignas bucais. Uma variante agressiva do carcinoma espinocelular, com predileção para a região de cabeça e pescoço, foi descrita por WAIN et al. ${ }^{82}$, em 1986, que sugeriram a denominação Carcinoma Escamoso Basalóide. Os primeiros dez casos descritos estavam localizados em mucosa e tecidos subjacentes da língua, hipofaringe e laringe. O principal aspecto microscópico deste tumor consiste num carcinoma com padrão basalóide intimamente associado com um carcinoma espinocelular, com displasia ou com diferenciação escamosa focal. O termo basalóide foi utilizado para descrever uma proliferação celular sólida com núcleos hipercromáticos, citoplasma escasso, pequenos espaços císticos e focos de necrose.

Quanto aos aspectos demográficos, os pacientes estudados por WAIN et al. ${ }^{82}$ apresentavam idades que variavam de 49 a 68 anos (média de 58,5 anos). Nove eram do gênero masculino e apenas um do gênero feminino, sendo cinco leucodermas e cinco melanodermas. Os tumores estavam localizados em hipofaringe (quatro casos), três casos na epiglote e três exclusivamente em base de língua. Com relação ao tratamento empregado, sete pacientes foram submetidos à excisão cirúrgica e radioterapia pós-operatória complementar e, destes pacientes, três também receberam quimioterapia. Um paciente recebeu apenas radioterapia paliativa e nos dois pacientes restantes o único tratamento empregado foi a excisão cirúrgica. No momento do diagnóstico inicial, seis pacientes tinham evidências de 
metástases em linfonodos regionais e quatro apresentavam metástases distantes. Cinco dos dez pacientes morreram num período de quatro anos após o início do tratamento.

A provável histogênese do CEB apresentada por WAIN et al. ${ }^{82}$ foi relacionada às células primitivas totipotentes. Sugeriu-se que estas células primitivas estavam localizadas na camada basal do epitélio colunar pseudo-estratificado ou nos ductos de glândulas salivares da laringe, hipofaringe e língua. A possibilidade de o carcinoma escamoso basalóide representar um tumor originado de uma união de dois tumores malignos foi desacreditada pelo fato de que os dois componentes, basalóide e escamoso, encontravam-se aleatoriamente distribuídos e que o tumor, embora pouco freqüente, não era raro.

Assim como com o CEC, o uso de tabaco e o consumo de álcool representam importantes fatores de risco para o $\mathrm{CEB}^{13,14,37,54}$. Os vírus Epstein-Barr $(\mathrm{EBV})$ ou do Papiloma Humano (HPV) podem desempenhar um papel no aparecimento de CEBs na região de nasofaringe, genital ou no canal anal, embora não se tenha evidência de infecção viral nos casos descritos em cavidade bucal ${ }^{37}$.

Após a descrição inicial de WAIN et al. ${ }^{82}$ em 1986, vários relatos têm sido apresentados na literatura sobre o comportamento agressivo do CEB. BARNES et al. ${ }^{14} \mathrm{e}$ ALTAVILLA et al. ${ }^{6}$ afirmaram que, apesar da Organização Mundial de Saúde ter incluído este tumor na sua edição revisada da Classificação Histológica dos Tumores do Trato Respiratório Superior e Ouvido de 1991, os CEBs não estão restritos apenas a esta região do corpo humano e tumores similares, se não idênticos, foram descritos no esôfago, pulmão, colo uterino e ânus. Outros termos foram usados para designar este fenótipo, tais como carcinoma basalóide, carcinoma de células basais adenóide, carcinoma com diferenciação adenóide cística ou carcinoma adenóide cístico-like. Quando presente no canal anal, esta neoplasia recebe a denominação de carcinoma cloacogênico. 
As principais características clínicas observadas nos pacientes portadores de CEBs na região de cabeça e pescoço são: maior prevalência em idosos (sexta e sétima décadas de vida) com história de consumo elevado de tabaco e álcool; maior freqüência no gênero masculino sendo os locais mais acometidos base de língua, seio piriforme e laringe; comportamento agressivo caracterizado por uma alta incidência de metástases em linfonodos cervicais e a distância nos pulmões, fígado, ossos, cérebro e pele; bem como um elevado índice de mortalidade. O diagnóstico da maioria dos tumores ocorre em estádios clínicos avançados (III e IV) determinando um pior prognóstico para os pacientes ${ }^{13,40,45,49,54,57}$. Os sintomas mais freqüentemente relatados pelos pacientes quando da anamnese são: dor de garganta, rouquidão, tosse, obstrução nasal ou epistaxe, disfagia, perda de peso, hemoptise e sudorese noturna ${ }^{13,54,57}$.

O primeiro relato de CEB acometendo a mucosa bucal foi o de CADIER et al. ${ }^{22}$, em 1992, cuja paciente era do gênero feminino, 83 anos, apresentando um nódulo de consistência firme, coloração semelhante à mucosa, com uma área de ulceração central, localizado na mucosa jugal. Interessantemente, a paciente informou que nunca teve o vício de consumir tabaco ou ingerir bebidas alcoólicas. Após este relato inicial, inúmeros trabalhos descreveram CEBs presentes em boca. Os locais mais comumente afetados foram: mucosa jugal ${ }^{26}$, assoalho bucal ${ }^{1,23,28,37,43}$, maxila $^{80,85}$, gengiva inferior ${ }^{2,43}$, trígono retromolar ${ }^{6}$, palato mole e orofaringe $^{6}$ e borda lateral de língua ${ }^{43}$. Além destas localizações, inúmeros relatos de CEBs presentes em base de língua foram apresentados ${ }^{13,27,40,45,49,54,57,82}$.

De modo semelhante aos CEBs de outras localizações da região de cabeça e pescoço, este tumor, quando presente em boca, parece apresentar um comportamento clínico e biológico agressivo. Entretanto, ABIKO et al. ${ }^{2}$ afirmaram que este comportamento está intimamente relacionado com as diversas localizações destes tumores na mucosa bucal. IDE 
et al. ${ }^{37}$, após estudarem $46 \mathrm{CEBs}$ de boca, observaram que esta neoplasia apresenta uma predileção para a base de língua, acomete com maior freqüência pacientes idosos (média de 61 anos) e do gênero masculino. Assim como com os CEBs de outras localizações da região de cabeça e pescoço, estes tumores são geralmente diagnosticados já em estádios avançados (III e IV). O CEB apresenta um comportamento agressivo caracterizado por um alto índice de comprometimento linfonodal regional quando do diagnóstico, além de metástases a distância. Recorrência local e recidiva regional são freqüentes. Os pacientes comumente apresentam um baixo índice de sobrevida.

O CEB pode exibir uma origem multifocal na mucosa, embora isto seja pouco freqüente ${ }^{14}$. Alguns autores sugerem que esta neoplasia maligna pode também estar associada com uma alta incidência de segundos tumores primários, sincrônicos ou metacrônicos, do trato aereodigestivo superior ${ }^{52,64,68}$. Dos 40 pacientes estudados por BANKS et al. ${ }^{13}$, dois apresentavam outros tumores malignos. Um paciente era portador de leucemia linfocítica crônica e o outro apresentava adenocarcinoma de cólon e próstata.

Os aspectos macroscópicos do CEB foram relatados pela primeira vez em 1989 por MCKAY; BILOUS ${ }^{52}$. As lesões geralmente apresentam-se como um nódulo exofítico, polipóide, com ulceração central, de consistência firme, coloração branca ou brancoamarelada e com infiltração submucosa periférica ${ }^{6,14}$.

Dentre os tumores malignos que mais facilmente podem ser confundidos com o CEB, destacam-se o carcinoma adenóide cístico com padrão sólido e o carcinoma indiferenciado de pequenas células $^{37}$. Em boca, são também incluídos no diagnóstico diferencial o adenocarcinoma polimorfo de baixo grau de malignidade, o adenocarcinoma de células basais, o carcinoma do ducto salivar, o carcinoma de célulares acinares, o carcinoma neuroendócrino e o carcinoma adenoescamoso ${ }^{14,27,28,37,43}$. 
Clinicamente, o diagnóstico diferencial é importante por razões terapêuticas e prognósticas. Como exemplo, pode-se destacar o carcinoma adenóide cístico que apresenta um comportamento clínico bem distinto em relação ao $\mathrm{CEB}$, caracterizado por uma menor incidência de comprometimento linfonodal regional, risco menos acentuado de recorrência local e um melhor índice de sobrevida. Com relação à terapêutica, o carcinoma neuroendócrino é tratado com protocolos quimioterapêuticos ${ }^{6,23}$.

Segundo WAIN et al. $^{82}$, as características microscópicas do carcinoma escamoso basalóide são distintas e específicas. O componente basalóide do tumor é definido pelos seguintes aspectos: proliferações celulares sólidas, em configuração lobular, apresentando continuidade com a mucosa superficial; células de pequeno tamanho e com citoplasma escasso; núcleos hipercromáticos; nucléolos pouco evidentes e pequenos espaços císticos contendo material semelhante à mucina que se cora pelo PAS e/ou Alcian blue. Outros aspectos microscópicos presentes são focos de necrose por coagulação, de tamanhos variados, presentes nas porções centrais das ilhotas, denominada comedonecrose. Uma hialinização do conjuntivo peritumoral eventualmente pode ser encontrada.

O segundo componente microscópico deste tumor consiste na presença de carcinoma espinocelular, invasivo ou in situ, de displasia ou de diferenciação escamosa focal. Os critérios utilizados para identificar o epitélio escamoso, como proposto por WAIN et al. ${ }^{82}$, é a presença de dois ou mais dos seguintes aspectos: queratinização de células isoladas, pontes intercelulares, formação de pérolas de queratina e células dispostas num padrão pavimentoso ou em mosaico.

Devido a sua composição heterogênea, é extremamente difícil, ou quase impossível, se estabelecer um diagnóstico de CEB baseando-se apenas em pequenos espécimes de biópsias incisionais $^{14,15}$. ABIKO et al. $^{2}$ sugeriram que, quando se estabelece um diagnóstico de CEC 
pouco diferenciado por meio de uma biópsia incisional, a possibilidade de se tratar de um CEB não deve ser descartada. SINGH et al. ${ }^{68}$ enfatizaram a necessidade de se utilizar cortes seriados múltiplos para que possam ser identificadas a região de diferenciação escamosa e a continuidade do tumor com o epitélio de revestimento.

Muitos pacientes com CEB apresentam ou desenvolvem metástases em linfonodos regionais. Os patologistas devem conhecer os aspectos citológicos desta neoplasia, pois muitos pacientes com comprometimento linfonodal serão submetidos à biópsia por agulha fina como procedimento diagnóstico inicial. Apesar de nenhum critério único ser considerado diagnóstico de CEB, a combinação de vários aspectos peculiares sugere seu diagnóstico. Esfregaços de CEBs contêm fragmentos de células neoplásicas coesivas e algumas células isoladas. As células são pequenas ou de tamanho médio e possuem pouco citoplasma. Os núcleos normalmente têm cromatina fina e granular com nucléolos pequenos ou não evidentes. Grandes células com nucléolos mais proeminentes podem também ser observadas. Queratinização de células isoladas podem ocasionalmente ser vistas. Entretanto, em alguns esfregaços de linfonodos cervicais pode ser difícil ou quase impossível distinguir um CEB de um carcinoma indiferenciado. Em tais situações, uma biópsia do linfonodo envolvido ou da lesão primária está indicada ${ }^{12}$.

Ultra-estruturalmente, as células basalóides são poligonais, com núcleo pálido contendo cromatina fina e dispersa. O citoplasma apresenta desmossomos, raros tonofilamentos e ribossomos livres, mas poucas outras organelas. Características ocasionais de malignidade foram vistas incluindo núcleos volumosos irregulares e vários nucléolos. Os espaços císticos visualizados à microscopia óptica são vistos circundados por membrana basal e com grânulos estrelados frouxos ou lâmina basal replicada em paralelo. Os aspectos ultraestruturais do componente escamoso do tumor são semelhantes aos das células escamosas, 
como desmossomos bem formados e depósitos de tonofilamentos. Não são observados grânulos neurossecretores, miofilamentos com corpúsculos densos, grânulos secretores, organização citoplasmática ou polaridade celular ${ }^{82}$. Estes aspectos ultra-estruturais também foram relatados por BARNES et al. ${ }^{14}$, BATSAKIS; EL NAGGAR ${ }^{15}$ e COPPOLA et al. ${ }^{28}$.

O prognóstico do $\mathrm{CEB}$ tem sido considerado desfavorável devido ao seu comportamento agressivo. O tumor freqüentemente é diagnosticado em estádios avançados e apresenta um comportamento clínico agressivo caracterizado por invasão perineural, metástases em linfonodos regionais e metástases em órgãos distantes como pulmões, ossos, cérebro e pele. Eventualmente, metástases distantes podem ser encontradas sem envolvimento linfonodal ${ }^{6}$.

O tratamento de escolha para os carcinomas escamosos basalóides consiste na combinação de excisão cirúrgica e radioterapia pós-operatória complementar. O esvaziamento cervical ipsilateral ou bilateral seletivo é recomendado devido à alta incidência de comprometimento linfonodal. Quimioterapia complementar à cirurgia, à radioterapia ou a ambas está indicada quando houver metástases distantes $6,14,23,45,49,57,80$.

Recentemente, KUNKEL et al. $^{43}$ afirmaram que a proservação dos pacientes portadores de CEB em boca constitui-se num problema desafiador em relação à necessidade de detecção inicial de recorrências e ao momento oportuno para a realização de cirurgias reconstrutoras, aspectos estes de suma importância para a qualidade de vida dos pacientes. Estes autores propuseram a utilização de um método diagnóstico denominado Tomografia por Emissão de Positrons (PET) com $\left[{ }^{18} \mathrm{~F}\right]$-2-fluorodeoxyglucose $\left(\left[{ }^{18} \mathrm{~F}\right] \mathrm{FDG}\right)$. Este método seria superior à tomografia computadorizada e à ressonância nuclear magnética para se detectar a ocorrência de recorrências locais num estádio inicial ou o aparecimento de metástases a distância pós-tratamento. 


\subsection{Carcinoma Escamoso Basalóide X Carcinoma Espinocelular}

Vários subtipos histológicos de CECs estão listados na última Classificação Histológica de Câncer Bucal da $\mathrm{OMS}^{55}$. Um destes, o CEB, tem sido considerado como uma variante de alto grau de malignidade. É geralmente aceito que os CEBs da região de cabeça e pescoço tendem a apresentar um comportamento clínico mais agressivo do que os CECs pareados pela localização e estadiamento, com recorrências locais freqüentes além de metástases regionais e distantes ${ }^{37}$. Entretanto, esta afirmação ainda apresenta bastante discordância entre os estudos presentes na literatura. Enquanto alguns autores $2,28,30,40,90$ sugerem que o CEB apresenta um comportamento clínico mais agressivo, outros afirmam que este comportamento é similar ao do $\mathrm{CEC}^{14,32,33,49}$.

LUNA et al. ${ }^{49}$ afirmaram, após analisarem os $11 \mathrm{CEBs}$ relatados na literatura, que o curso clínico e os índices de sobrevida parecem ser menores que os dos CECs. Entretanto, nos nove CEBs por eles estudados, os índices de sobrevida e a incidência de metástases nos linfonodos regionais foram semelhantes aos observados nos CECs pareados pela localização anatômica, tratamento e estádio clínico.

Em 1992, BANKS et al. ${ }^{13}$ relataram que pacientes com CEB apresentam aspectos clínicos similares àqueles associados com CEC presentes nas mesmas regiões de cabeça e pescoço. O CEB é uma neoplasia agressiva que freqüentemente produz metástase resultando em morte do paciente. Embora inicialmente se acreditasse que o CEB era mais agressivo que o CEC, o CEB exibe um comportamento similar ao CEC pouco diferenciado.

O primeiro estudo comparando o comportamento clínico e o índice de sobrevida do CEB localizado exclusivamente em boca com o CEC foi desenvolvido por COPPOLA et al. ${ }^{28}$ em 1993. Eles avaliaram, através dos aspectos clinicopatológicos e imuno-histoquímicos, oito CEBs localizados em assoalho bucal comparativamente com um grupo de 63 CECs de mesma 
localização. Os parâmetros prognósticos analisados foram estadiamento, tamanho do tumor, número de mitoses, embolização vascular e linfática, infiltração perineural, comprometimento linfonodal, metástase a distância, comportamento agressivo local, sobrevida e tratamento. Os CECs foram subdivididos em dois grupos representados por 22 CECs bem diferenciados e 41 pouco diferenciados. Os resultados deste estudo demonstraram que o CEB apresentou um comportamento mais agressivo, representado por um elevado índice de recorrência local e metástase a distância, além de um pior prognóstico caracterizado por baixos índices de sobrevida.

KLIJANIENKO et al. ${ }^{40}$ observaram um comportamento mais agressivo dos CEBs. Os 12 pacientes por eles acompanhados desenvolveram recorrências locais e metástases distantes mais freqüentemente quando comparados com os dez portadores de CEC.

BARNES et al. ${ }^{14}$ relataram que, embora se considere o CEB um tumor que apresenta um pior prognóstico quando comparado com o CEC, quando estes tumores são pareados pela localização, estadiamento e tratamento empregado, eles normalmente apresentam índices de sobrevida semelhantes.

SARBIA et al. ${ }^{60}$ e LAM et al. $^{44}$, após analisarem comparativamente os aspectos clinicopatológicos, imuno-histoquímicos e a atividade da telomerase em CEBs e CECs de esôfago, relataram que os CEBs apresentaram um alto grau de indiferenciação e uma alta atividade proliferativa. Entretanto, o prognóstico dos pacientes com CEB de esôfago não difere daqueles pacientes com CEC típico. Resultados semelhantes relativos ao prognóstico foram obtidos por WIENEKE; THOMPSON; $\mathrm{WENIG}^{87}$ quando estudaram os aspectos microscópicos e o comportamento biológico dos CEBs presentes no trato aereodigestivo superior. 
FERLITO et al. $^{30}$ descreveram os aspectos clínicos e microscópicos de 15 CEBs presentes em laringe (nove casos) e hipofaringe (seis casos), avaliando o comportamento e a história natural desta neoplasia através da comparação com oito carcinomas adenóides císticos e com dez CECs. Os pacientes foram tratados através de cirurgia, radioterapia e quimioterapia pós-operatórias. Após a análise dos resultados, os autores apresentaram as seguintes conclusões referentes aos CEBs por eles estudados: 1- ocorrem com maior freqüência em pacientes adultos, do gênero masculino e geralmente são diagnosticados em estádios avançados; 2- possuem um comportamento clínico agressivo caracterizado por um elevado índice de metástases regionais e a distância, comumente em pulmão; 3- os pacientes com estes tumores apresentam uma tendência para desenvolverem segundos tumores primários, sincrônicos ou metacrônicos, no trato aereodigestivo superior; 4- cirurgia e radioterapia apresentam índices satisfatórios de controle da doença, estando a quimioterapia indicada no tratamento de metástases distantes e 5- o prognóstico normalmente é pior do que o do CEC convencional.

Em 1997, ABIKO et al. ${ }^{1}$ estabeleceram a primeira linhagem celular derivada de um CEB de assoalho bucal. Após compararem esta linhagem com duas outras linhagens celulares, clones pouco e altamente invasivos, derivadas de um CEC de língua, os autores concluíram que as células desta linhagem exibiram um alto grau de invasividade. Em outro estudo, ABIKO et al. ${ }^{2}$ avaliaram a atividade proliferativa de dois CEBs localizados em gengiva e assoalho bucal através do número de regiões organizadoras nucleolares coradas pela prata (AgNORs) por núcleo. Ficou demonstrado neste estudo que a atividade proliferativa do CEB foi maior que a de CECs de mesma localização. Estes resultados apoiaram a hipótese de que o CEB apresenta um maior índice de proliferação e um pior prognóstico quando comparado com o CEC. 
WINZENBURG et al. ${ }^{90}$ compararam os aspectos clínicos de 26 CEBs da região de cabeça e pescoço com 23 CECs pouco diferenciados pareados quanto à localização e estadiamento. Os CEBs foram também classificados como tendo mais de $90 \%$ de células basalóides ou como apresentando os aspectos basalóide e escamoso. A relação entre os aspectos microscópicos e a sobrevida não demonstrou diferença estatisticamente significativa devido ao pequeno número de casos presentes em cada categoria. Os pacientes que apresentavam CEB contendo ambos os componentes escamoso e basalóide tiveram um pior prognóstico com relação à sobrevida, potencial para o desenvolvimento de metástases distantes e recorrência local. Uma provável explicação para isto é que a presença ou ausência de comedonecrose, invasão perivascular ou linfática e hialinização estromal afetariam o comportamento do tumor, sendo estas características mais observadas nos CEBs que apresentavam os componentes escamoso e basalóide. A sobrevida média para os pacientes com CEB foi consideravelmente menor do que a dos pacientes com CEC pouco diferenciado, além do fato que o índice de metástase a distância foi maior. Estes autores observaram ainda que pacientes portadores de CEB com comprometimento linfonodal apresentaram um baixo índice de sobrevida. Como a maioria dos pacientes por eles investigada possuía tumores avançados (estádios III e IV), esperava-se que um grande número destes pacientes também apresentasse comprometimento linfonodal e, portanto, um pior prognóstico. Mesmo assim, o grupo CEB apresentou um menor índice de sobrevida em relação ao CEC pouco diferenciado quando ambos apresentavam comprometimento linfonodal. Com base nestes achados, estes autores concluíram que o CEB representa uma variante mais agressiva do CEC.

COLETTA et al. $^{26}$ afirmaram que o comportamento biológico do CEB tem se mostrado pior que o do CEC convencional e que os pacientes com estas neoplasias apresentam um prognóstico desfavorável. Entretanto, estes autores estudaram apenas dois 
casos de CEBs afetando a mucosa bucal e, portanto, poucos dados a respeito das propriedades biológicas influenciando o prognóstico puderam ser avaliadas. Após analisarem a expressão de AgNOR, PCNA e p53 nos dois CEBs localizados em mucosa jugal, comparativamente aos dois CECs pouco diferenciados pareados pela idade, gênero, localização e estadiamento TNM, concluíram que o CEB tem um comportamento mais agressivo do que os CECs pouco diferenciados. Estes autores também sugeriram que o comportamento clínico do CEB será melhor entendido quando os dados clínicos e microscópicos forem considerados em conjunto com novas técnicas moleculares que estão se tornando disponíveis.

Em 2003, GÓES ${ }^{32}$ avaliou a morfologia tumoral e a expressão dos marcadores de proliferação celular e apoptose PCNA, p53, Bax e Bcl-X em 17 CEBs localizados em boca comparando-os com 27 CECs pouco diferenciados com localização e estadiamento equivalentes. Os seguintes aspectos clínicos foram analisados: gênero, idade, raça, tabagismo, etilismo, localização do tumor primário, classificação pelo sistema $\mathrm{TNM}^{77}$, tratamento, ocorrência de recorrência local, metástases em linfonodos regionais, a distância e segundos tumores primários. Os resultados deste estudo demonstraram que as probabilidades de sobrevida global, sobrevida específica e sobrevida livre de doença acumuladas em cinco e dez anos para os pacientes com CEB e com CEC de boca foram semelhantes. O estadiamento clínico $\mathrm{N}$ constituiu um fator de prognóstico independente para os pacientes com CEB e CEC pouco diferenciado na mucosa bucal. A morfologia tumoral bem como a expressão dos anticorpos PCNA, p53, Bax e Bcl-X não foram fatores prognósticos significativos. A autora concluiu que o $\mathrm{CEB}$ e o CEC pouco diferenciado com localização e estadiamento clínico equivalentes em boca apresentam comportamento clínico e biológico similares. Assim sendo, sugeriu-se que os pacientes acometidos por estes tumores podem ser submetidos aos mesmos protocolos terapêuticos. 
Recentemente, GÓES et al. ${ }^{33}$ também compararam os dados clínicos e os aspectos prognósticos em 17 pacientes portadores de CEB, em 27 portadores de CEC pouco diferenciado e em 27 pacientes com CEC bem a moderadamente diferenciado. Todos os pacientes se submeteram a tratamento cirúrgico e 52 também receberam radioterapia pósoperatória. A análise dos resultados revelou que não houve diferença estatisticamente significativa nas sobrevidas global, específica e livre de doença entre os três grupos de carcinomas. Os autores concluíram que o comportamento clínico do CEB é similar aos comportamentos clínicos dos CECs pouco diferenciado e bem a moderadamente diferenciados de boca, quando estes tumores são pareados pelos estadiamentos $\mathrm{T}$ e N. O prognóstico dos pacientes com $\mathrm{CEB}$ de boca não difere do apresentado pelos CECs convencionais. 


\subsection{Antígeno Nuclear de Proliferação Celular (PCNA)}

Nas últimas décadas, mesmo com os recentes avanços no diagnóstico e tratamento do câncer bucal, o índice de sobrevida dos pacientes não tem apresentado alterações significativas $^{81}$. O prognóstico do CEC, principal neoplasia maligna que afeta a boca, tem sido determinado pelo estadiamento clínico baseado no sistema TNM associado à graduação histológica do tumor ${ }^{35}$.

As evidências mais recentes, segundo JACOB et al. ${ }^{38}$, têm demonstrado que os tumores malignos são muito heterogêneos em termos de sua biologia tumoral. Os diferentes genótipos das células neoplásicas expressos pela grande variedade de fenótipos presentes nos CECs podem determinar comportamentos biológicos divergentes para lesões com estadiamentos clínicos semelhantes.

O comportamento biológico dos tumores malignos como, por exemplo, do CEC de boca depende em parte de sua atividade proliferativa, ou seja, da relação entre as células em proliferação e aquelas células neoplásicas que estão em apoptose ${ }^{91}$. Geralmente, tumores malignos que apresentam altos índices de proliferação estão associados com um pior prognóstico e uma resposta mais pobre à quimio e à radioterapia, quando comparados com neoplasias malignas com baixos índices proliferativos. Tem sido verificado que, em alguns tumores malignos de diferentes órgãos, o valor prognóstico dos fatores de proliferação excede aquele dos fatores de prognóstico bem estabelecidos, tais como comprometimento dos linfonodos, estadiamento, diferenciação e ploidia do DNA ${ }^{8}$.

A proliferação celular nos tumores malignos pode ser determinada por métodos sofisticados tais como: contagem das células com marcação dos precursores do DNA (timidina, uridina) ou extrapolação da porcentagem de células na fase-S através de histogramas de citometria de fluxo de DNA. Além disso, a morfologia nuclear (nucléolo, tipo 
de cromatina) e as regiões organizadoras nucleolares bem como os antígenos nucleares como Ki-67, antígeno nuclear de proliferação celular (PCNA), dentre outras proteínas também estão associados com a proliferação das células neoplásicas malignas ${ }^{8}$.

A imuno-histoquímica oferece vantagens sobre outros métodos de análise da proliferação celular tumoral, tais como seqüenciamento de DNA e análise da reação em cadeia da polimerase, pois, além de ser de fácil execução e economicamente viável, permite grande reprodutibilidade ${ }^{29}$.

$\mathrm{O}$ antígeno nuclear de proliferação celular (PCNA) representa um antígeno nuclear que aparece durante o final da fase G1, aumenta durante a fase S e declina durante as fases G2 e M. O PCNA é essencial para a síntese de DNA na divisão celular normal e no reparo do DNA. Ele consiste numa proteína de $36 \mathrm{kDa}$ e, apesar de ser essencial para a síntese de DNA na fase $\mathrm{S}$, tem uma longa meia-vida e está presente em níveis detectáveis em muitas células não evidentemente em ciclo. A presença do PCNA pode, portanto, representar células na fase $\mathrm{S}$, células que tenham passado pela fase $\mathrm{S}$ ou células que tenham sofrido algum dano no DNA $^{5,18,50,56,58,63}$.

O tempo de fixação dos tecidos afeta a imunomarcação pelo PCNA. Bons resultados são observados após 24 a 36 horas, enquanto que um tecido fixado por mais de 48 horas apresentará uma redução significativa na intensidade da coloração. Em tecidos adequadamente fixados, uma coloração positiva é predominantemente nuclear, embora uma marcação citoplasmática seja ocasionalmente observada em células com núcleos mitóticos. A graduação da intensidade da coloração deve ser realizada nas camadas basal e suprabasal do epitélio estratificado ${ }^{84}$.

O valor clínico dos marcadores de proliferação para o prognóstico dos tumores da região de cabeça e pescoço é ainda sujeito a debate. Enquanto alguns estudos ${ }^{3,70,81,91}$ têm 
demonstrado que tumores com altos índices de proliferação apresentam menores índices de sobrevida, outros não conseguiram estabelecer esta correlação ${ }^{32,41,69,74}$.

TSAI; JIN ${ }^{78}$, em 1995, estudando a expressão do PCNA em 28 pacientes portadores de CECs de boca de diferentes estadiamento $\mathrm{T}$ e graduação histopatológica, concluíram que a porcentagem de células tumorais positivamente coradas pelo PCNA aumentou significativamente entre um tumor com menos de dois centímetros e um tumor com mais de dois centímetros. Entretanto, não se observou aumento semelhante nesta porcentagem em tumores de mesmo tamanho embora houvesse uma diminuição do grau de diferenciação histopatológica.

ALLISON; BEST ${ }^{5}$ (1998) não observaram correlação entre a intensidade de coloração pelo PCNA e o grau de diferenciação dos 24 CECs de boca por eles estudados. Mas houve uma distribuição variada quanto à localização dos marcadores de proliferação dentro de um mesmo tumor. Nas regiões mais profundas do tumor que invadiam o tecido conjuntivo subjacente, as células localizadas mais externamente nas ilhotas tumorais apresentaram uma coloração fortemente positiva pelo PCNA em relação às células presentes no centro das ilhotas.

Em 1999, SITTEL et al. ${ }^{69}$ avaliaram o significado prognóstico dos marcadores de proliferação celular Ki-67 (MIB-1), PCNA e p53 em 56 CECs de orofaringe e cavidade bucal. Os tumores foram divididos em 26 CECs que não apresentaram recorrências locais e 26 que apresentaram recorrências locais. Todos os 56 pacientes foram tratados através da excisão cirúrgica dos tumores e radioterapia pós-operatória complementar. Os resultados deste estudo revelaram que o PCNA não apresentou valor prognóstico. Por outro lado, a expressão do Ki67, segundo estes autores, estava intimamente associada com um prognóstico desfavorável. 


\subsection{Moléculas de Adesão Celular}

Desde que foi inicialmente reconhecido que as neoplasias malignas possuem a capacidade de invadir tecidos adjacentes e disseminar para órgãos distantes, inúmeras pesquisas têm sido realizadas visando à expansão do conhecimento sobre estas características marcantes destas neoplasias. Os estudos têm revelado que, para que uma metástase se desenvolva, este processo deve ser coordenado, realizado em múltiplas etapas e iniciar-se com o desprendimento de células do tumor primário que se deslocarão até órgãos distantes originando tumores ${ }^{16}$.

De acordo com ALBELDA ${ }^{4}$, os principais eventos observados durante o crescimento tumoral e o desenvolvimento de metástases são: 1- crescimento tumoral, invasão e desprendimento de células neoplásicas do tumor primário; 2- movimentação das células tumorais pelos vasos linfáticos e/ou sangüíneos; 3- sobrevivência destas células na circulação e interação com as plaquetas; 4- adesão das células tumorais em órgãos distantes através de interações com o endotélio vascular e/ou membrana basal subendotelial; 5- migração celular no parênquima tecidual do órgão afetado e 6- crescimento do tumor no local metastático. Contudo, em carcinomas não invasivos, estes eventos não ocorrem, pois as células individuais estão interconectadas por uma complexa rede de adesões célula-célula. Somente a destruição de tais interações pode permitir que células neoplásicas malignas migrem para além do tumor primário $^{62}$.

O processo metastático é regulado por uma variedade de produtos sintetizados a partir de genes específicos. Estes incluem receptores de ligação célula-célula e de ligação célulamatriz extracelular; enzimas proteolíticas que facilitam a degradação e invasão da membrana basal, vasos sangüíneos e/ou linfáticos e órgãos; fatores de motilidade que permitem a migração através dos tecidos; receptores que atuam como mediadores da invasão de um órgão 
específico; fatores de crescimento necessários para a manutenção das microcolônias neoplásicas no órgão secundário e fatores angiogênicos responsáveis pela neovascularização do foco metastático, permitindo o suprimento de nutrientes, remoção de metabólitos e disseminação hematogênica de células metastáticas ${ }^{16,88}$.

O enfraquecimento da adesão célula-célula é um requisito fundamental para que as células neoplásicas malignas produzam metástases. Nos últimos anos, algumas moléculas de adesão celular, bioquímica e geneticamente distintas, foram descritas. Dentre estas, destacamse as integrinas, a superfamília das imunoglobulinas, as selectinas, as caderinas e o determinante celular CD44 $4,16,39,83$. Tem sido sugerido que, possivelmente, todas as moléculas de adesão contribuem, em maior ou menor proporção, com o controle do comportamento das células neoplásicas ou com o direcionamento da resposta imune antitumoral ${ }^{83}$.

A superfamília das imunoglobulinas compreende moléculas que são independentes do cálcio cujos domínios estão relacionados às imunoglobulinas. As integrinas são proteínas heterodiméricas, originalmente conhecidas como receptores para moléculas da matriz extracelular. Também são mediadoras da adesão célula-célula por se ligarem através de ligações heterotípicas a membros da superfamília das imunoglobulinas. As selectinas foram as moléculas de adesão mais recentemente identificadas e são representadas pela L-, E- e Pselectina. São mediadoras das ligações dos leucócitos às células endoteliais, dos linfócitos nos linfonodos e auxiliam no extravasamento dos leucócitos granulócitos nos tecidos inflamados. Estas selectinas se ligam a grupos carboidratos específicos através dos domínios de lectina ${ }^{39}$. O termo CD44 define um grupo de proteínas da superfície celular com diferentes pesos moleculares que variam de 85 a $160 \mathrm{kDa}$. A proteína de $90 \mathrm{kDa}$ é a forma predominante nos leucócitos enquanto que as isoformas maiores (de 150 a 160 kDa) são encontradas em células 
epiteliais e mesenquimais atuando como um receptor para o ácido hialurônico na matriz extracelular ${ }^{4,11}$.

As caderinas representam uma família de moléculas de adesão celular transmembranosas, dependentes do cálcio, que se ligam através de ligações homofílicas. São importantes não apenas no estabelecimento e manutenção das uniões intercelulares, mas também na determinação da especificidade adesiva das células ${ }^{75,86}$. Geralmente, células com poucas moléculas de caderina apresentam menor adesividade. São também essenciais no desenvolvimento da polaridade celular e no estabelecimento da morfologia tecidual ${ }^{75}$. O cálcio é essencial para a função adesiva das caderinas e para protegê-las contra a digestão pelas proteases $^{39,86}$.

A denominação "caderina" foi sugerida inicialmente por Takeichi em 1984, para caracterizar um "sistema de adesão celular dependente do cálcio"66,86,93. As caderinas são divididas em subclasses de acordo com sua distribuição tecidual. A nomenclatura deriva-se do tecido no qual estas glicoproteínas foram inicialmente identificadas. A caderina epitelial (Ecaderina), também conhecida como uvomorulina, molécula de adesão celular 120/80 (CAM 120/80), ou Arc-1 (em cães), é encontrada em células epiteliais de indivíduos adultos. A caderina neural (N-caderina), também chamada A-CAM ou N-Cal-CAM, foi inicialmente identificada em tecidos neurais e musculares adultos. Já a P-caderina foi encontrada inicialmente na placenta e no epitélio, embora possa ser expressa em outros tecidos durante o desenvolvimento. Além destas três principais subclasses, existem também a B-caderina (encontrada no cérebro) e a L-CAM (caderina do fígado de galinha) $)^{4,39,66,72,88}$.

Em adultos, quase todos os tipos de epitélio expressam E-caderina e P-caderina. A Ecaderina geralmente está uniformemente distribuída em todas camadas do epitélio, com exceção da camada mais superficial, enquanto que a P-caderina está concentrada mais 
intensamente na camada basal ${ }^{4}$. Estas moléculas de adesão não estão aleatoriamente distribuídas sobre as superfícies celulares, mas tendem a localizar-se nas junções especializadas denominadas junções aderentes, onde desempenham um papel fundamental no desenvolvimento destas estruturas ${ }^{72}$.

O gene que codifica a E-caderina humana é o $C D H 1$ situado no braço longo do cromossomo 16. A E-caderina possui um peso molecular de aproximadamente $120 \mathrm{kDa}$ sendo composta por três domínios, um citoplasmático, um transmembranoso e um extracelular, que consiste de cinco subdomínios numerados (C1-C5), onde $\mathrm{C} 1$ representa o mais distante da membrana celular. Este subdomínio C1 contém três aminoácidos dispostos em uma seqüência: histidina, alanina-valina (HAV) sendo essencial para o processo de adesão célulacélula $^{16,34,71}$.

O domínio extracelular da E-caderina se liga, através de ligações homofílicas dependentes do cálcio, ao domínio extracelular de uma molécula de E-caderina de uma célula vizinha, assumindo uma conformação de um "zipper molecular"16,34,36,88. O domínio citoplasmático da E-caderina está ligado à actina do citoesqueleto através de interações heterotípicas com as moléculas denominadas cateninas. O complexo E-caderina/catenina é composto pela $\alpha$-catenina $(102 \mathrm{kDa})$, pela $\beta$-catenina $(92 \mathrm{kDa})$ e pela $\gamma$-catenina $(83 \mathrm{kDa})$, também conhecida como plakoglobina.

Os genes que codificam as cateninas estão localizados no braço longo do cromossomo 5 ( $\alpha$-catenina), no braço curto do cromossomo 3 ( $\beta$-catenina) e no braço longo do cromossomo 17 ( $\gamma$-catenina $)^{16,39,72}$. A quarta molécula semelhante a catenina (catenina-like), a p120 ${ }^{\text {ctn }}$ (também conhecida como p120 $0^{\text {cas }}$ ), foi recentemente descrita e o seu gene está localizado no braço longo do cromossomo 11 , imediatamente adjacente ao centrômero ${ }^{16,88}$. 
A $\beta$-catenina e a $\gamma$-catenina se ligam ao domínio citoplasmático da E-caderina, enquanto que a $\alpha$-catenina une a $\beta$-catenina ou a $\gamma$-catenina a rede de microfilamentos de actina do citoesqueleto. Desta forma, numa mesma célula existem dois complexos distintos de E-caderina/catenina, um sendo composto por E-caderina, $\beta$-catenina e $\alpha$-catenina e o outro representado pela E-caderina, $\gamma$-catenina e $\alpha$-catenina ${ }^{16,88}$.

OZAWA; BARIBAULT; KEMLER ${ }^{53}$, em 1989, foram os primeiros a sugerir o nome catenina a estas proteínas. Este termo deriva-se do latim catena (ou cadeia) e está relacionado à principal função das cateninas, que consiste na ligação das moléculas de adesão dependentes do cálcio ao citoesqueleto.

Alterações na expressão da E-caderina pode ocorrer tanto em processos fisiológicos como em patológicos. Dentre os fisiológicos, destaca-se a reação das células epiteliais na cicatrização de feridas. O fechamento da ferida numa camada epitelial requer não apenas uma redução da adesão celular, mas também uma estimulação da motilidade celular. As alterações apresentadas pelas células epiteliais são induzidas pela liberação de citocinas e outras substâncias ativas após a lesão tecidual. De particular importância é o papel exercido pelo Fator de crescimento epidérmico (EGF) e sua interação com o seu receptor (EGFR). Assim que o defeito tenha se fechado, a adesão celular é desregulada permitindo que o epitélio retome sua resistência inicial ${ }^{16}$.

Um complexo E-caderina/catenina é um requisito fundamental para a manutenção da adesão intercelular normal. Sendo assim, inúmeros estudos têm indicado que, em carcinomas, a E-caderina atua como uma molécula supressora da invasão e que a sua perda permitiria ou aumentaria o risco de invasão nos tecidos normais subjacentes. De modo geral, a imunomarcação da E-caderina e das cateninas é mais intensa nos tumores bem diferenciados, que mantêm sua adesividade celular e são menos invasivos, mas é reduzida em tumores pouco 
diferenciados que perderam a adesão célula-célula e mostram um comportamento fortemente invasivo. Alterações na expressão da E-caderina podem, conseqüentemente, ser um importante passo no desenvolvimento e progressão de um tumor maligno ${ }^{16,36,71,88}$.

Estudos imuno-histoquímicos de muitos diferentes tipos de carcinomas humanos têm demonstrado que parte destes tumores apresenta níveis reduzidos de expressão de E-caderina em comparação aos tecidos normais relacionados. A perda de E-caderina é mais pronunciada naqueles carcinomas que possuem um padrão de crescimento infiltrativo associado com pouca ou nenhuma coesão intercelular. Conseqüentemente, a expressão anormal do complexo Ecaderina/catenina correlaciona-se com as seguintes características neoplásicas: grau de diferenciação, invasividade, infiltração vascular, comprometimento linfonodal, presença de metástases distantes e o estádio tumoral. A detecção imuno-histoquímica de E-caderina e cateninas pode ser útil não apenas para se predizer as sobrevidas global e livre de doença, mas também para identificar pacientes com linfonodos clinicamente negativos com um elevado risco oculto de metástases, aos quais está indicada a realização de um esvaziamento cervical $\operatorname{radical}^{88}$.

Estudos avaliando conjuntamente a expressão dos marcadores E-caderina e de uma das cateninas são de melhor valor prognóstico do que a avaliação destes componentes individualmente. De acordo com WIJNHOVEN; DINJENS; PIGNATELLI ${ }^{88}$, uma alteração em qualquer uma destas moléculas pode levar a uma desregulação no funcionamento do complexo. Como as cateninas têm um papel crítico no controle da adesão mediada pela caderina, isto indica que a imunorreatividade nem sempre implica na presença de um complexo caderina/catenina funcionalmente normal. Deste modo, para se predizer a invasão e metástases em carcinomas, é mais conveniente investigar não apenas a expressão de Ecaderina, mas também a expressão das cateninas. 
Em 1991, SCHIPPER et al. ${ }^{62}$ avaliaram a expressão de E-caderina em 32 CECs da região de cabeça e pescoço. Os resultados deste estudo demonstraram que todos os cinco CECs pouco diferenciados não expressaram E-caderina, enquanto que os 15 tumores moderadamente diferenciados expressaram este marcador num padrão heterogêneo e intermediário. Por outro lado, a expressão de E-caderina nos 12 CECs bem diferenciados freqüentemente era tão intensa quanto no epitélio normal. Com relação aos linfonodos metastáticos, estes foram negativos para a E-caderina. Os autores concluíram que, de fato, a E-caderina exerce um importante papel na progressão dos CECs e que a diminuição da expressão está associada com a perda da diferenciação e com o aparecimento de metástases.

BOWIE et al. ${ }^{17}$ estudaram a expressão imuno-histoquímica de E-caderina em 28 pacientes que apresentavam 17 CECs primários localizados em hipofaringe, três em orofaringe, dois em laringe e dois em boca. Além destes tumores, foram também estudadas nove metástases em linfonodos regionais. Destes 33 tumores, 16 apresentaram uma redução na expressão de E-caderina e os demais apresentaram uma coloração semelhante ao epitélio normal. Dos 18 CECs moderadamente diferenciados, nove apresentaram uma imunomarcação positiva e em nove houve uma redução da imunoexpressão epitelial. Três dos quatro CECs pouco diferenciados se caracterizaram por uma perda da expressão da E-caderina. Dos oito CECs moderadamente diferenciados presentes nos linfonodos, houve uma expressão fraca em $50 \%$ das lesões. Entretanto, não se observou uma diferença estatisticamente significativa quando se comparou a expressão reduzida da E-caderina nos CECs pouco e bem a moderadamente diferenciados. Este estudo também não demonstrou uma associação entre a expressão de E-caderina e a análise multivariada de sobrevida. Não houve correlação entre a expressão deste marcador e os fatores: idade, sexo, condição geral, localização, estadiamentos 
$\mathrm{T}$ e N, recidiva local, recidiva cervical e sobrevida. Os autores concluíram que a expressão de E-caderina em CECs primários da região de cabeça e pescoço não apresenta um valor clínico. MATTIJSSEN et al. ${ }^{51}$ avaliaram a expressão imuno-histoquímica de E-caderina em 50 CECs da região de cabeça e pescoço (27 localizados em laringe e 23 em boca), avaliando as porcentagens de células epiteliais que apresentavam uma coloração membranosa em cortes por congelação a fresco. Os resultados demonstraram que houve uma correlação significativa entre o nível de expressão membranosa da E-caderina e o grau de diferenciação, entretanto nenhuma correlação foi observada entre a expressão da E-caderina e os estadiamentos $\mathrm{T}$ e $\mathrm{N}$. Com relação à sobrevida, os pacientes que apresentaram os melhores índices de sobrevida tinham altos níveis de coloração membranosa nos tumores primários. Estes resultados sugerem que a expressão membranosa de E-caderina apresenta importância prognóstica em pacientes com CECs da região de cabeça e pescoço.

Em 1994, SAKAKI et al. ${ }^{59}$ desenvolveram o primeiro estudo avaliando a expressão de E-caderina e P-caderina em 25 CECs localizados exclusivamente em gengiva. Os tumores estavam localizados na região de molares e pré-molares, estando três em maxila e 22 em mandíbula. Os tumores foram graduados histopatologicamente como bem diferenciados (nove casos), moderadamente diferenciados (12 casos) e pouco diferenciados (quatro casos). Os autores observaram que a expressão reduzida da E-caderina foi significativamente mais elevada em CECs pouco diferenciados de gengiva, sugerindo uma correlação inversa entre a expressão deste marcador e o grau de diferenciação. Os resultados também demonstraram que a desregulação desta molécula de adesão é um evento maligno comum na progressão dos CECs de gengiva estando isto intimamente relacionado como o padrão de invasão da neoplasia. 
Outros estudos como o de FRANCHI et al. ${ }^{31}$ investigaram o valor preditivo da atividade proliferativa, utilizando os anticorpos MIB-1 e PCNA, e a expressão imunohistoquímica de E-caderina em 30 pacientes portadores de CECs de laringe com um elevado risco de metástase linfonodal oculta. Todos os pacientes apresentavam linfonodos cervicais clinicamente negativos e se submeteram a um esvaziamento eletivo no pescoço, com subseqüente determinação histopatológica de metástases ocultas ( $\mathrm{N}$ positivo patológico). Um grupo de 30 pacientes submetidos a tratamento para carcinomas espinocelulares de laringe com linfonodos clínica e patologicamente negativos foi utilizado como controle. Os autores observaram que, em carcinomas espinocelulares de laringe, uma alta atividade proliferativa avaliada pela imunomarcação com PCNA e MIB-1 associada a uma redução na expressão da molécula de adesão E-caderina correlacionaram-se significativamente com a presença de metástases ocultas em linfonodos. Os resultados deste estudo também demonstraram que houve uma perda significativa da expressão de E-caderina nos CECs pouco diferenciados e que a perda da diferenciação dos tumores foi também acompanhada pela localização citoplasmática da E-caderina. Dentre os parâmetros histopatológicos tradicionais avaliados, como graduação histopatológica, padrão de crescimento, número de mitoses, e infiltrado inflamatório, apenas o grau de diferenciação demonstrou uma correlação significativa com a presença de metástases ocultas. Entretanto, na análise multivariada, este parâmetro não se constituiu num fator independente de prognóstico.

A relação entre a expressão imuno-histoquímica de E-caderina e o estadiamento clínico e o grau de diferenciação dos CECs de boca foi avaliada por YAMADA et al. ${ }^{92}$ em 1997. Foram utilizados 16 CECs primários, sendo três bem, 11 moderadamente e quatro pouco diferenciados, dois linfonodos metastáticos e seis fragmentos de mucosa bucal normal como controle. Observou-se que, nos linfonodos metastáticos, as células localizadas mais no 
centro das ilhotas tumorais apresentavam uma imunomarcação positiva pela E-caderina, enquanto que, nos tumores primários, a expressão foi reduzida. Para estes autores, esta característica indica que a perda da expressão da E-caderina pode facilitar a motilidade das células neoplásicas causando metástases nos linfonodos, onde há uma re-expressão desta molécula de adesão permitindo que estas células novamente se agrupem e cresçam. Os resultados ainda revelaram que a redução da expressão da E-caderina foi mais proeminente nas células periféricas das ilhotas tumorais localizadas na região do front de invasão tumoral. Os autores concluíram que a perda da expressão de E-caderina correlacionou-se positivamente com os estadiamentos $\mathrm{T}$ e $\mathrm{N}$ mais avançados e com a perda da diferenciação dos CECs de boca por eles estudados.

O primeiro estudo avaliando a expressão conjunta de E-caderina e $\beta$-catenina em CECs da região de cabeça e pescoço foi desenvolvido por ANDREWS et al. ${ }^{7}$ em 1997. Foram estudados 33 tumores primários e 18 linfonodos metastáticos, estando os tumores primários localizados em boca (dez casos), orofaringe (cinco casos), laringe (seis casos), hipofaringe (dez casos) e em locais não identificados os restantes. Os autores não encontraram uma associação significativa entre a graduação histopatológica dos tumores e as seguintes características: localização do tumor, estadiamentos $\mathrm{T}$ e $\mathrm{N}$ e sobrevida. Não se observou também diferença estatisticamente significativa entre a graduação histopatológica dos tumores primários que desenvolveram metástases em linfonodos regionais e a dos que não apresentaram metástases. A E-caderina expressou-se mais intensamente em células com uma maior diferenciação escamosa, mas não houve correlação entre a diminuição da expressão de ambas as moléculas de adesão e a recorrência local, metástases distantes e sobrevida. Estes autores concluíram que a perda da expressão das moléculas E-caderina e $\beta$-catenina é uma 
anormalidade comum em CECs e, apesar de estarem relacionadas com as metástases, não são os melhores indicadores de prognóstico para os pacientes.

BAGUTTI et al. ${ }^{9}$ investigaram a distribuição das moléculas de adesão integrinas, caderinas $(E, N$ e $P)$ e cateninas $(\alpha, \beta$ e $\gamma)$ em 22 CECs de boca, sendo 19 primários e três tumores recorrentes. Com relação ao grau de diferenciação, quatro CECs eram bem diferenciados, 13 eram moderadamente diferenciados e seis eram pouco diferenciados. $\mathrm{Na}$ análise estatística, os CECs bem e moderadamente foram agrupados e comparados com os pouco diferenciados. Foram realizadas reações imuno-histoquímicas de dupla marcação para os anticorpos dos grupos das caderinas e das cateninas. A expressão da E-caderina correlacionou-se com o grau de diferenciação dos tumores, pois os CECs pouco diferenciados apresentaram o menor índice de imunomarcação. Observou-se também uma redução na coloração das cateninas em todos os tumores. Com base nestes resultados, os autores concluíram que a expressão reduzida das cateninas independe do grau de diferenciação dos carcinomas.

A expressão imuno-histoquímica das moléculas de adesão caderinas (E e P) e cateninas $(\alpha, \beta$ e $\gamma)$ foi examinada durante o processo de carcinogênese bucal comparando sua expressão em epitélios normais e displásicos e em CECs primários e metastáticos por WILLIANS et al. ${ }^{89}$. A amostra consistiu de 12 CECs bucais, 12 fragmentos epiteliais displásicos e oito fragmentos de mucosa bucal normal. Os autores observaram que, na mucosa bucal normal, a P-caderina está localizada nas camadas basal e parabasal do epitélio enquanto que a E-caderina e as cateninas estão distribuídas em todas as camadas com exceção da camada córnea. Isto sugere que a P-caderina está presente apenas no compartimento proliferativo do epitélio e que a E-caderina está presente em células que já se dividiram e se moveram para as camadas celulares mais diferenciadas. A presença de cateninas e de E- 
caderina nos compartimentos mais superficiais reflete a íntima associação destas moléculas de adesão formando os complexos E-caderina $/ \beta$-catenina/ $\alpha$-catenina ou E-caderina $/ \gamma$-catenina $/ \alpha$ catenina. Nos CECs, a redução ou perda da expressão da E-caderina e das cateninas foi associada com a perda da diferenciação e com o desenvolvimento de metástases. A perda da expressão de E-caderina no front de invasão tumoral poderia ser um indicativo para a disseminação metastática e possivelmente como um indicador de prognóstico, entretanto, são necessários mais estudos para se confirmar esta associação com o prognóstico.

SHINOHARA et al. ${ }^{67}$ estudaram, dentre outros marcadores imuno-histoquímicos, a intensidade da imunomarcação da E-caderina em 54 CECs primários de boca. Destes, apenas 28 apresentavam comprometimento linfonodal. A maioria dos tumores estava localizada em língua (dez casos), gengiva (seis em mandíbula e dois em maxila), soalho bucal (cinco casos), mucosa jugal (três casos) e somente dois tumores estavam localizados no palato. Os autores concluíram que a redução da expressão de E-caderina correlacionou-se com o comportamento invasivo e metastático de todos os carcinomas espinocelulares. Entretanto, não houve uma correlação entre a perda da expressão da E-caderina e o grau de diferenciação.

Em 1999, LO MUZIO et al. ${ }^{47}$ afirmaram que, embora a expressão imuno-histoquímica de E-caderina em muitos tumores malignos humanos, incluindo os CECs de boca, tenha sido bastante estudada, pouco se investigou sobre os níveis de expressão das cateninas no câncer bucal. Estes autores avaliaram o papel das cateninas ( $\beta$ e $\gamma$ ) em 30 CECs de boca, sendo 12 bem diferenciados, dez moderadamente diferenciados e oito pouco diferenciados. A avaliação da imunomarcação foi realizada de acordo com a porcentagem de células positivamente coradas e a localização do marcador, se membranosa ou citoplasmática. Nos tumores estudados, a maioria dos CECs bem diferenciados apresentou uma imunomarcação predominantemente membranosa enquanto que, nos CECs moderadamente e pouco 
diferenciados, houve um predomínio de imunomarcação citoplasmática. Os resultados demonstraram uma similaridade no padrão de coloração entre o epitélio normal e os CECs bem diferenciados, apoiando a existência de uma estreita relação entre a expressão de $\beta$ catenina e de $\gamma$-catenina e o grau de diferenciação celular. Além disso, a redução da intensidade da imunomarcação foi observada principalmente nas bordas periféricas dos tumores com padrão de invasão compressivo ou nos cordões sólidos, finos ou em células isoladas. Como conclusões, os autores afirmaram que a análise da expressão imunohistoquímica de cateninas em CECs de boca pode ser útil para a identificação de regiões do tumor com um potencial mais agressivo, sobretudo em CECs bem a moderadamente diferenciados. Esta avaliação deve ser feita em conjunto com a expressão de E-caderina e outros marcadores convencionais da proliferação celular.

TSUBOCHI et al. ${ }^{79}$ estudaram, dentre outros marcadores, a expressão imunohistoquímica de E-caderina e $\alpha$-catenina em sete CEBs de esôfago. Comparou-se a expressão destes marcadores nestes tumores com a expressão em carcinomas mucoepidermóides, em carcinomas adenóides císticos, em CECs moderadamente e pouco diferenciados e em adenocarcinomas. Os resultados demonstraram que houve uma redução na expressão de Ecaderina em todos os CEBs e uma expressão reduzida de $\alpha$-catenina na maioria destes tumores do grupo CEB. Os autores concluíram que esta expressão reduzida de E-caderina e $\alpha$-catenina nos CEBs pode estar correlacionada com um comportamento mais agressivo.

CHOW et al. $^{25}$ avaliaram a expressão das moléculas de adesão do complexo Ecaderina/catenina em 85 CECs de língua. Além destes tumores primários, estudou-se também a expressão destes marcadores em nove linfonodos metastáticos e em sete tumores que apresentaram recidiva local. A graduação histopatológica dos CECs era a seguinte: 28 bem diferenciados, 50 moderadamente diferenciados e sete pouco diferenciados. Todos os 
pacientes se submeteram a tratamento cirúrgico e 32 também receberam radioterapia pósoperatória complementar. A análise dos resultados revelou que a redução da expressão de Ecaderina e de cateninas $(\alpha, \beta$ e $\gamma)$ não se correlacionou com o gênero, idade, grau de diferenciação ou estádio patológico. Não houve também correlação com metástases em linfonodos regionais, com recidiva local e o índice de sobrevida livre de doença aos cinco anos foi de $57 \%$. A análise multivariada com o modelo de regressão de Cox incluindo o estadiamento TNM, o comprometimento linfonodal patológico e a expressão de E-caderina demonstrou que apenas o estadiamento TNM e a expressão de E-caderina foram fatores de prognóstico independentes para a sobrevida.

O estudo desenvolvido por BÁNKFALVI et al. ${ }^{11}$, em 2002, teve como objetivo definir se a perda da expressão de CD44, E-caderina e $\beta$-catenina correlacionava-se ou não com a evolução clínica e com o prognóstico do câncer bucal. Foram estudados 93 CECs primários de boca, 30 metástases associadas e 12 tumores recorrentes. Os CECs estavam localizados em língua e soalho bucal e o tratamento oferecido a todos os pacientes foi uma excisão cirúrgica acompanhada de radioterapia pós-operatória. A expressão das moléculas de adesão foi comparada com os principais fatores indicadores de prognóstico, tais como tamanho do tumor, comprometimento linfonodal, grau de diferenciação histopatológica e a análise do front de invasão tumoral. A perda da expressão da $\beta$-catenina correlacionou-se significativamente com a presença de linfonodos positivos. Na análise multivariada com o modelo de regressão de Cox, somente o estadiamento $\mathrm{N}$ e a graduação do índice de malignidade no front de invasão tumoral foram fatores prognósticos independentes, sendo estes parâmetros estatisticamente significativos. Entretanto, o real valor prognóstico das moléculas de adesão nos CECs requer um maior número de estudos com uma casuística mais 
selecionada, utilizando-se CECs em estádios iniciais para reduzir a influência de eventos genéticos e fenotípicos irrelevantes.

A relação entre a expressão imuno-histoquímica de E-caderina e $\beta$-catenina com o prognóstico dos 106 pacientes portadores de CECs de esôfago, submetidos à esofagectomia, foi investigada por ZHAO et al. ${ }^{94}$. Doze pacientes receberam radioterapia e 15 quimioterapia pós-operatórias. Os resultados demonstraram que pacientes apresentando tumores com uma redução na expressão de $\beta$-catenina e tumores com uma ausência da expressão do complexo E-caderina/ $\beta$-catenina apresentaram os menores índices de sobrevida global. Os autores concluíram que somente a expressão de E-caderina correlacionou-se com as sobrevidas global e livre de doença, estando isto intimamente associado com o prognóstico dos pacientes portadores de CEC de esôfago.

A expressão imuno-histoquímica das moléculas de adesão celular E-caderina, $\alpha$ catenina e $\beta$-catenina no processo de metástases em linfonodos regionais de 159 CECs primários de boca foi estudada por TANAKA et al. ${ }^{76}$. Os tumores estavam localizados em língua (84 casos), gengiva maxilar (sete casos), gengiva mandibular (26 casos), soalho bucal (27 casos), mucosa jugal (13 casos) e lábio (dois casos). Todos os pacientes foram submetidos a tratamento cirúrgico para excisão das lesões. O comprometimento linfonodal confirmado microscopicamente $(\mathrm{pN}+)$ foi observado em 64 pacientes, sendo os 95 restantes $\mathrm{pN}$-. Dos 159 CECs analisados, houve uma expressão reduzida de E-caderina, $\alpha$-catenina e $\beta$-catenina em $92(57,9 \%), 115(72,3 \%)$ e $114(71,7 \%)$, respectivamente, estando isto correlacionado significativamente com a ocorrência de metástases em linfonodos regionais. O índice de sobrevida global dos pacientes que apresentaram uma redução na expressão das moléculas de adesão estudadas foi significativamente menor quando comparado ao dos pacientes cujos 
tumores possuíam uma expressão preservada destas moléculas. Como conclusões, os autores sugeriram que a investigação imuno-histoquímica de E-caderina, $\alpha$-catenina e $\beta$-catenina contribui para se diagnosticar a presença de metástases.

LIM et al. $^{46}$ avaliaram os marcadores preditivos para metástases cervicais tardias em 56 pacientes com CECs invasivos de língua. Todos os pacientes apresentavam estadiamento clínico I e II e os tumores eram T1-2 (24 T1 e 32 T2) sem comprometimento linfonodal (N0). Glossectomia parcial sem esvaziamento cervical foi o tratamento empregado em todos os pacientes. Os aspectos microscópicos examinados foram espessura do tumor, padrão de invasão, graduação histopatológica de BRODERS ${ }^{19}$, índice total de malignidade de BRYNE et al. ${ }^{21}$, forma das ilhotas tumorais, invasões vasculares linfática e sangüínea e infiltração perineural. Avaliou-se também a expressão imuno-histoquímica dos seguintes marcadores: p53, ciclina D1, Ki-67, receptor para o fator de crescimento epidérmico (EGFR), ciclooxigenase-2 (Cox-2), densidade microvascular, laminina, E-caderina e $\beta$-catenina. Todos os fatores clinicopatológicos e a expressão imuno-histoquímica dos marcadores foram comparados em termos de sobrevida global. Os resultados demonstraram que, na análise multivariada, a espessura do tumor, a graduação histopatológica de malignidade de BRODERS $^{19}$, a forma das ilhotas, o padrão de invasão, o índice de malignidade de BRYNE et al. ${ }^{21}$ e a expressão de E-caderina correlacionaram-se com metástases cervicais tardias. A análise multivariada sobre metástase cervical tardia revelou que a espessura tumoral acima de quatro milímetros, os padrões de invasão em cordões finos e em células isoladas e a expressão de E-caderina foram fatores independentes de prognóstico. Os autores concluíram que, pacientes com CECs de língua T1-2 com uma espessura de mais de quatro milímetros, com padrões de invasão em cordões finos ou em células isoladas e com uma redução na expressão de E-caderina, devem ser considerados um grupo de alto risco para o desenvolvimento de 
metástases tardias. Sendo assim, nestes pacientes está também indicada a realização de esvaziamento cervical eletivo.

A localização e o nível de expressão de $\beta$-catenina foram avaliados por LOPEZGONZALEZ et al. $^{48}$ em 38 CECs de laringe, sendo 14 bem diferenciados, dez moderadamente diferenciados e 14 pouco diferenciados. O epitélio normal dos cortes microscópicos foi utilizado como controle interno. A localização celular e o nível de expressão de $\beta$-catenina foram avaliados semiquantitativamente. Estes autores observaram que uma imunomarcação membranosa estava presente no epitélio normal e nos CECs bem a moderadamente diferenciados. Entretanto, nos carcinomas pouco diferenciados o marcador estava localizado com maior freqüência no citoplasma. Como conclusões, a redução da expressão de $\beta$-catenina correlacionou-se com a perda da diferenciação tumoral. 
3 PROPOSIÇÃO 


\section{PROPOSIÇÃO}

A partir da análise dos carcinomas espinocelulares bem, moderadamente e pouco diferenciados e do carcinoma escamoso basalóide com localização e estadiamento equivalentes na boca, propusemos:

3.1 caracterizar e comparar as características demográficas, clínicas e morfológicas destes tumores;

3.2 comparar a expressão imuno-histoquímica dos anticorpos PCNA, E-caderina e $\beta$-catenina nestes tumores;

3.3 verificar a existência de correlação entre os marcadores imuno-histoquímicos e as demais características clínicas e microscópicas analisadas;

3.4 avaliar o valor prognóstico dos marcadores imuno-histoquímicos PCNA, Ecaderina e $\beta$-catenina nos pacientes com carcinomas espinocelulares e carcinoma escamoso basalóide. 
4 MATERIAL E MÉTODOS 


\section{MATERIAL E MÉTODOS}

\subsection{População de Estudo e Seleção da Amostra}

O estudo foi desenvolvido a partir de uma análise retrospectiva de pacientes submetidos a tratamento de carcinomas espinocelulares primários de boca, com estádios clínicos I, II, III e IV, no Departamento de Cirurgia de Cabeça e Pescoço e Otorrinolaringologia do Centro de Tratamento e Pesquisa do Hospital do Câncer AC Camargo (São Paulo-SP), no período de 1970 a 2000. Parte desta amostra foi previamente analisada por GÓES ${ }^{32}$ em 2003.

Os seguintes critérios de inclusão e exclusão da amostra de carcinomas espinocelulares descritos por KOWALSKI et al. ${ }^{42}$ foram utilizados:

\section{Critérios de inclusão:}

1. pacientes com tumor primário cujo diagnóstico era de carcinoma espinocelular, confirmado por biópsia e exame anatomopatológico prévios, localizado em língua, soalho bucal, gengiva inferior e região retromolar;

2. pacientes não submetidos a tratamento prévio;

3. pacientes submetidos à cirurgia como tratamento inicial com ou sem radioterapia pós-operatória;

4. seguimento clínico completo;

5. disponibilidade dos blocos de parafina dos referidos tumores, bem como a adequada conservação dos espécimes;

6. disponibilidade de fragmentos representativos das neoplasias. 


\section{Critérios de exclusão:}

1. contra-indicação cirúrgica, ou seja, pacientes considerados inoperáveis;

2. presença de metástase à distância no momento de admissão no hospital;

3. presença de tumores primários simultâneos;

4. pacientes submetidos à quimioterapia como tratamento inicial;

5. pacientes que recusaram o tratamento.

Os carcinomas espinocelulares de boca selecionados foram divididos, de acordo com as características microscópicas, em três grupos.

GRUPO 1- Carcinomas Escamosos Basalóides (CEB)

GRUPO 2- Carcinomas Espinocelulares Pouco Diferenciados (CEC/PD)

GRUPO 3- Carcinomas Espinocelulares Bem a Moderadamente Diferenciados (CEC/BD)

Estes três grupos foram pareados pelo estadiamento clínico e pela localização das lesões na boca.

No GRUPO 1, os critérios morfológicos utilizados para a seleção dos carcinomas escamosos basalóides foram baseados na descrição inicial de WAIN et al. ${ }^{82}$, definidos pelas seguintes características:

1. proliferação sólida de células basalóides dispostas numa configuração lobular e justapostas ao epitélio de revestimento;

2. pequenas ilhotas de células com citoplasma escasso;

3. células com núcleo hipercromático, sem nucléolos evidentes;

4. pequenos espaços císticos contendo material similar à mucina e positivos ao PAS e/ou Alcian Blue;

5. focos de necrose por coagulação nas áreas centrais dos lóbulos tumorais; 
6. associação dos componentes basalóide e escamoso, este último caracterizado por focos de células com diferenciação escamosa, focos de displasia epitelial e/ou carcinoma espinocelular;

7. hialinização do estroma.

Os critérios morfológicos para a identificação do componente escamoso nos cortes microscópicos de carcinoma escamoso basalóide foram constituídos pela presença da queratinização individual de células, presença de pontes intercelulares, de pérolas córneas e do arranjo pavimentoso ou em mosaico do epitélio estratificado.

A seleção dos carcinomas espinocelulares bucais foi realizada a partir dos critérios tumorais morfológicos estabelecidos pela Organização Mundial de Saúde ${ }^{55}$, baseados no método originalmente descrito por BRODERS ${ }^{19}$ em 1920, caracterizados por:

GRUPO 2: Grau 3 da $O M S$ - carcinomas espinocelulares pouco diferenciados microscopicamente, apresentando discreta queratinização, pontes intercelulares escassas, diversas mitoses atípicas e pleomorfismo celular e nuclear intensos.

GRUPO 3: Graus 1 e 2 da OMS- carcinomas espinocelulares bem a moderadamente diferenciados apresentando proeminente queratinização, poucas figuras de mitose, discreto pleomorfismo celular e pontes intercelulares ainda evidentes.

\subsection{Registro dos Dados Clínicos e Microscópicos}

As informações clínicas referentes aos pacientes bem como os dados microscópicos relativos à peça cirúrgica foram registrados em formulário próprio (Anexo 1), adaptado de KOWALSKI et al. ${ }^{42}$ e modificado por GÓES $^{32}$, obtidas a partir do banco de dados pertencente ao Hospital do Câncer AC Camargo, São Paulo. Estes registros incluíram a identificação e os dados demográficos dos pacientes, informações relativas à história clínica, 
ao exame locorregional, cirurgia, radioterapia e quimioterapia pós-operatórias, microscopia da peça cirúrgica inicial e evolução dos pacientes. No caso dos pacientes vivos, a evolução clínica foi atualizada até o ano de 2004 por meio de consulta aos respectivos prontuários arquivados no SAME (Serviço de Arquivo Médico) do referido hospital.

\subsection{Análise Microscópica}

Realizou-se a análise morfológica qualitativa dos espécimes selecionados em cortes microscópicos de $3 \mu \mathrm{m}$ de espessura obtidos a partir das peças cirúrgicas incluídas em parafina dos carcinomas espinocelulares bem a moderadamente diferenciados, pouco diferenciados e carcinomas escamosos basalóides bucais, arquivados no Laboratório de Anatomia Patológica do Hospital do Câncer. Estes cortes foram corados pela técnica da Hematoxilina e Eosina (HE) seguindo-se os procedimentos histotécnicos de rotina do Laboratório de Anatomia Patológica do referido hospital.

A análise morfológica dos tumores primários foi realizada individualmente por três examinadores (JACH, GL, DTO) utilizando-se de um microscópio óptico binocular ZEISS, modelo Axioskop2 plus, sendo os pontos de discordância entre estes reavaliados e estabelecidos por um consenso. Utilizou-se um corte representativo do tumor primário de cada caso, analisando-se todo o fragmento neoplásico presente na lâmina para a determinação das características microscópicas relativas ao padrão de configuração e morfologia tumoral.

A avaliação da graduação histopatológica de malignidade nas áreas mais invasivas dos carcinomas espinocelulares de boca foi realizada utilizando-se o sistema de BRYNE et al. ${ }^{21}$. A área do front de invasão tumoral de cada espécime foi percorrida e analisada por três examinadores utilizando-se um microscópio óptico ZEISS (modelo Axioskop2 plus) e objetiva de 40X. Para cada carcinoma espinocelular, o componente individual do sistema de 
graduação da invasividade tumoral foi analisado por meio de categorias que variavam de 1 a 4 pontos (Tabela 1), sendo posteriormente somadas num índice total de malignidade que variava de 5 a 20 pontos. Os carcinomas espinocelulares foram considerados pouco (índice total $\leq 10$ ) ou muito agressivos (índice total $>10$ ).

TABELA 1 - Sistema de graduação do front de invasão tumoral de BRYNE et al. ${ }^{21}$

\begin{tabular}{|c|c|c|c|c|}
\hline \multirow[b]{2}{*}{$\begin{array}{c}\text { Características } \\
\text { Morfológicas } \\
\end{array}$} & \multicolumn{4}{|c|}{ GRADUAÇÃO } \\
\hline & 1 & 2 & 3 & 4 \\
\hline $\begin{array}{c}\text { Grau de } \\
\text { Queratinização }\end{array}$ & $\begin{array}{c}\text { Alta } \\
\text { queratinização } \\
(>50 \% \text { das } \\
\text { células })\end{array}$ & $\begin{array}{c}\text { Moderada } \\
\text { queratinização } \\
\text { (21-50\% das } \\
\text { células) }\end{array}$ & $\begin{array}{c}\text { Mínima } \\
\text { queratinização } \\
\text { (6-20\% das } \\
\text { células) }\end{array}$ & $\begin{array}{c}\text { Ausência de } \\
\text { queratinização } \\
\text { (0-5\% das } \\
\text { células) }\end{array}$ \\
\hline $\begin{array}{l}\text { Pleomorfismo } \\
\text { nuclear }\end{array}$ & $\begin{array}{c}\text { Discreto }(>75 \% \\
\text { das células } \\
\text { maduras })\end{array}$ & $\begin{array}{l}\text { Moderado (51 a } \\
75 \% \text { das células } \\
\text { maduras })\end{array}$ & $\begin{array}{c}\text { Intenso ( } 26 \text { a } \\
50 \% \text { das células } \\
\text { maduras })\end{array}$ & $\begin{array}{c}\text { Extremo ( } 0 \text { a } \\
\text { 25\% das células } \\
\text { maduras })\end{array}$ \\
\hline $\begin{array}{l}\text { Número de } \\
\text { mitoses }\end{array}$ & 0 a 1 & 2 a 3 & 4 a 5 & $>5$ \\
\hline $\begin{array}{l}\text { Padrão de } \\
\text { invasão }\end{array}$ & $\begin{array}{l}\text { Compressivo, } \\
\text { bordas bem } \\
\text { definidas }\end{array}$ & $\begin{array}{l}\text { Cordões grossos, } \\
\text { sólidos, de } \\
\text { células tumorais }\end{array}$ & $\begin{array}{l}\text { Cordões finos de } \\
\text { células tumorais }\end{array}$ & $\begin{array}{c}\text { Células tumorais } \\
\text { isoladas ou } \\
\text { dissociadas em } \\
\text { pequenos grupos }\end{array}$ \\
\hline $\begin{array}{c}\text { Infiltrado } \\
\text { inflamatório }\end{array}$ & Intenso & Moderado & Discreto & Ausente \\
\hline
\end{tabular}

\subsection{Variáveis de Estudo}

As variáveis analisadas neste estudo referem-se aos dados demográficos relativos aos pacientes como o gênero (masculino ou feminino), a idade e a raça (branca, ou não branca).

Quanto à história clínica dos pacientes, pesquisou-se o tempo de história (meses), tabagismo e etilismo. Analisaram-se também as queixas dos pacientes, se referentes ao tumor primário, às metástases regionais ou a ambos. No exame locorregional, a localização do tumor 
primário foi registrada como: 1- ponta de língua; 2- corpo de língua; 3- ponta e corpo de língua; 4- sulco pelve-lingual; 5- soalho bucal; 6- gengiva inferior e 7- área retromolar.

Quanto às características clínicas, as lesões foram descritas como ulcerovegetantes ou ulceroinfiltrativas.

Registraram-se as classificações clínicas TNM/UICC ${ }^{77}$, T (T1, T2, T3, T4 e Tx) e N (N0, N1, N2a, N2b, N2c e N3), agrupando-as para análise em T1-2 e T3-4, N0 e N+.

Quanto ao tratamento, registrou-se a data da cirurgia, a realização ou não de esvaziamento cervical, o tipo de esvaziamento cervical (ipsilateral ou ipsilateral e contralateral simultâneos), a data da alta hospitalar e a realização ou não de radioterapia e quimioterapia pós-operatórias.

A análise microscópica inicial da peça cirúrgica baseou-se primeiramente no diagnóstico do tumor primário referente ao laudo anatomopatológico (CECI, CECII, CECIII, CEB, Ca indiferenciado).

Classificou-se o componente basalóide e o padrão de invasão (sólido ou lobular, trabecular, tubular, cribiforme). Verificou-se a continuidade da neoplasia com a mucosa bucal (presente, ausente/mucosa não observada).

Analisou-se a presença ou ausência de características morfológicas e histoquímicas como: disposição em paliçada das células periféricas das ilhotas tumorais, pontes intercelulares, figuras de mitoses, espaços císticos e estruturas ductiformes e sua positividade ao PAS, disjunção epitélio tumoral-conjuntivo. Avaliou-se a necrose central por coagulação (ausente, presente) e a hialinização (ausente, intratumoral, peritumoral ou ambas).

O componente escamoso associado foi avaliado quanto a sua distribuição (intercalado às células basalóides ou adjacente ao componente basalóide). Verificou-se a presença ou a ausência de pontes intercelulares, disqueratoses e pérolas córneas. 
A evolução dos pacientes foi avaliada pela ocorrência ou não de recidiva local, cervical, de metástase a distância e de segundo tumor primário.

Com o objetivo de caracterização da amostra, registraram-se também a data da primeira recidiva, os locais da recidiva (0- não teve; 1- local; 2- pescoço ipsilateral; 3pescoço contralateral; 4- pulmão; 5- osso; 6- fígado; 7- outra à distância; 8- recidiva em local ignorado e 9- ignorado), a data do diagnóstico do segundo tumor primário e o local do segundo tumor primário.

Foram registradas a data da última informação de seguimento e a situação do paciente: 1- vivo sem evidência da doença (000); 2- vivo com câncer; 3- morte por intercorrência cirúrgica (MOCI); 4- morte decorrente do câncer (MOCA); 5- morte por outras causas não relacionadas ao câncer (MOASS) e 6- perdido de vista. Pacientes perdidos de vista eram considerados aqueles com menos de cinco anos de seguimento que deixaram de retornar por um período igual ao dobro estipulado. Pacientes assintomáticos perdidos de vista após cinco anos foram classificados como vivos livres da doença. Os prontuários dos pacientes perdidos de vista foram encaminhados aos responsáveis pela convocação destes pacientes e as respostas obtidas foram posteriormente conferidas.

\subsection{Método Imuno-histoquímico}

As marcações imuno-histoquímicas dos espécimes tumorais nos três grupos estudados seguiram os protocolos de reações utilizados no Laboratório de Imuno-histoquímica do Instituto Ludwig de Pesquisas, São Paulo-SP, utilizando-se da técnica estreptavidina-biotinaperoxidase para os seguintes anticorpos:

1. PCNA, clone PC10, Dako, código M0879, título pré-estabelecido: 1:6000;

2. E-caderina, clone 36, BD Transduction, código C20820, título pré-estabelecido 1:700; 
3. $\beta$-catenina, clone 14, BD Transduction, código C19220, título pré-estabelecido 1:1000.

As reações foram realizadas observando-se o seguinte protocolo:

Desparafinização dos cortes de $3 \mu \mathrm{m}$ de espessura em lâminas Superfrost Plus, (Erviegas), deixando-as por 24 horas em estufa à temperatura de $60^{\circ} \mathrm{C}$, em xilol a $60^{\circ} \mathrm{C}$ e em xilol a temperatura ambiente por 20 minutos cada. Em seguida, os cortes foram hidratados em etanol em concentrações decrescentes e lavados em água corrente e destilada.

A recuperação antigênica para a marcação imuno-histoquímica dos anticorpos foi realizada por meio da incubação dos espécimes em solução tampão citrato $10 \mathrm{mM}$ pH 6,0 , usando uma panela de pressão como fonte geradora de calor úmido por quatro minutos. Resfriamento por dez minutos sob água corrente e dez minutos a temperatura ambiente sem a tampa. Lavagem das lâminas em água corrente e destilada e posterior bloqueio da peroxidase endógena com Água Oxigenada (dez volumes), realizando-se quatro trocas de cinco minutos cada. Após este bloqueio, as lâminas foram novamente lavadas em água corrente e destilada e com solução salina tamponada com fosfato (PBS- phosphate buffered saline) $10 \mathrm{mM} \mathrm{pH} \mathrm{7,4,}$ por cinco minutos.

Os espécimes foram incubados com os anticorpos primários diluídos em tampão PBS contendo albumina bovina, BSA 1\% (Sigma, A9647, EUA) e azida sódica $\left(\mathrm{NaN}_{3}\right)$ 0,1\%, por 16 a 18 horas a $4^{\circ} \mathrm{C}$ em câmara úmida.

Os espécimes foram então incubados com o anticorpo secundário biotinilado-reagente C (Biotinylated affinity-isolated goat anti mouse/rabbit Ig) do kit de detecção StreptABComplex/HRP Duet (mouse/rabbit), Dako A/S K0492, Dinamarca, em título préestabelecido de 1:200, diluído em PBS, por um período de 30 minutos a $37^{\circ} \mathrm{C}$. Posteriormente, foram incubados com o complexo reagente A (Streptavidin) e reagente B 
(biotinylated peroxidase) desse mesmo kit em título preestabelecido de 1:200 por 30 minutos a $37^{\circ} \mathrm{C}$.

O produto final da reação antígeno-anticorpo foi visualizado por meio da incubação dos espécimes em solução substrato cromógeno 3,3' Diaminobezidine Tetrahydrochloride 60mg\% (Sigma D-5637 EUA); Dimetilsulfóxido 1mL; $\mathrm{H}_{2} \mathrm{O}_{2}$ 6\% (20 volumes) $1 \mathrm{~mL}$, PBS $100 \mathrm{~mL}$, por cinco minutos a $37^{\circ} \mathrm{C}$, ao abrigo da luz.

Os espécimes foram contracorados com solução de Hematoxilina de Harris por um minuto e em seguida montados com a utilização de resina adesiva Entellan Neu (Merck 1,07961 Alemanha) e lamínulas.

Controles positivo e negativo foram utilizados para cada anticorpo. Para o anticorpo PCNA utilizou-se como controle positivo, fragmento de tecido normal de tonsila humana e, como controle negativo, um corte representativo deste tecido com omissão do anticorpo primário específico no procedimento imuno-histoquímico.

Para os anticorpos E-caderina e $\beta$-catenina, utilizou-se como controles positivos um espécime de dermatofibroma e um fragmento de intestino, respectivamente. Como controles negativos, utilizou-se um corte representativo destes tecidos com omissão do anticorpo primário específico nos procedimentos imuno-histoquímicos.

\subsection{Avaliação Imuno-histoquímica}

A avaliação da expressão imuno-histoquímica do anticorpo PCNA nos espécimes de $\mathrm{CEB}, \mathrm{CEC} / \mathrm{PD}$ e CEC/BD foi realizada individualmente por meio de um sistema computadorizado de captura de imagens da região do front de invasão tumoral. Um total de 30 campos microscópicos de cada espécime tumoral para o anticorpo analisado foi capturado a partir de uma câmera (marca SAMSUNG, modelo SCC-131) acoplada ao microscópio 
(Axioskop2 plus, marca ZEISS) com objetiva de 40X. Esta câmera encontrava-se conectada a um microcomputador (INTEL-Pentium IV) contendo um sistema de processamento e análise de imagens (Image Lab - Softium Informática Ltda - ME). Cada imagem microscópica capturada pelo programa correspondia a uma área de $10.704,0116 \mu \mathrm{m}^{2}$. O valor total da área dos 30 campos seqüencialmente analisados, na região do front de invasão tumoral de cada espécime correspondia a $321.120,348 \mu \mathrm{m}^{2}$.

A avaliação da expressão do anticorpo nuclear PCNA foi realizada a partir da quantificação da porcentagem de células tumorais positivas, determinadas pela coloração acastanhada dos núcleos, contadas num total de mil células tumorais no front de invasão em cada espécime. A partir do valor mediano de marcação obtido para o PCNA nos grupos de carcinomas (CEB, CEC/PD e CEC/BD), codificaram-se as variáveis contínuas em variáveis categóricas. Para a avaliação da expressão do anticorpo PCNA, utilizaram-se as categorias $\leq 61 \%$ e $>61 \%$ de marcações positivas.

Os anticorpos E-caderina e $\beta$-catenina foram avaliados por método semiquantitativo de escores, baseado na somatória da proporção de células tumorais imunopositivas, na intensidade da expressão dos marcadores utilizados e na localização celular (membranosa ou citoplasmática) da imunomarcação:

A proporção das células tumorais positivas foi dividida em três grupos:

- $\mathbf{0}=\leq 10 \%$ de células tumorais positivas;

- $\quad \mathbf{1}=11$ a $50 \%$ de células tumorais positivas;

- $\mathbf{2}=>50 \%$ de células positivas.

A intensidade da imunomarcação foi avaliada:

- $\quad \mathbf{0}=$ ausência de imunomarcação; 
- $\mathbf{1}$ = imunomarcação fraca;

- $\mathbf{2}$ = imunomarcação forte.

A localização celular da imunomarcação foi dividida em três grupos:

- $\mathbf{0}=$ ausente;

- $\quad \mathbf{1}$ = marcação citoplasmática;

- $\mathbf{2}$ = marcação membranosa.

A somatória dos escores, baseada na proporção, intensidade e localização da Ecaderina ou $\beta$-catenina, foi classificada em:

- $\quad \mathbf{0}$ - $\mathbf{4}$ = Escore 1 = imunomarcação ausente ou fraca;

- 5 - 6 = Escore 2 = imunomarcação forte.

A análise imuno-histoquímica dos carcinomas primários foi realizada individualmente por três examinadores (JACH, GL, DTO) sem prévio conhecimento da graduação histopatológica de malignidade e/ou da evolução clínica dos pacientes.

\subsection{Análise Estatística}

Os registros das informações clínicas e microscópicas dos pacientes com CEB, com CEC/PD e com CEC/BD foram armazenados num banco de dados, elaborado em planilha do Microsoft Excel. As análises estatísticas foram realizadas utilizando-se o programa para microcomputador STATA versão 7.0 (StataCorp. 2001) $)^{73}$.

Primeiramente, para a verificação das diferenças entre as médias das idades, foi utilizado o teste $t$ Student e, posteriormente, a variável idade foi categorizada. Para avaliar a associação entre as variáveis demográficas, clínicas e microscópicas realizou-se o teste exato de Fisher ou o teste qui-quadrado, com o nível de significância igual a 5\%. 
A análise de sobrevida foi feita pelo estimador produto-limite de Kaplan-Meier. A comparação entre as curvas de sobrevida foi realizada pelo teste log-rank, com o nível de significância igual a 5\%. O tempo de seguimento para a obtenção da sobrevida global foi calculado em meses entre a data da cirurgia do tumor primário e o óbito ou até a data da última informação objetiva do paciente.

Consideraram-se para a análise da sobrevida livre de doença, o tempo em meses decorrido entre a cirurgia do tumor primário e o aparecimento da recorrência tumoral ou até a última informação objetiva do seguimento no caso da não ocorrência do evento em foco.

Foram considerados "não censurados" para os cálculos das sobrevidas global e livre de doença todos os casos em que ocorreu um evento de interesse (óbito para a sobrevida global e recorrência tumoral para a sobrevida livre de doença). Os casos em que os eventos não ocorreram até a data da última informação objetiva do seguimento foram classificados como "censurados".

Utilizou-se o modelo de regressão de Cox para avaliar a independência da variante histológica (CEB, $\mathrm{CEC} / \mathrm{PD}$ e $\mathrm{CEC} / \mathrm{BD})$ em relação às demais variáveis estudadas, na determinação do prognóstico. O método "stepwise backward procedure" foi utilizado para seleção das variáveis independentes do modelo de regressão de Cox, considerando-se o nível de significância de $10 \%$ para a inclusão das variáveis. 


\subsection{Registro Fotográfico}

Os campos microscópicos tumorais mais representativos dos grupos CEB, CEC/PD e CEC/BD corados pela $\mathrm{HE}$ e imunomarcados pelo PCNA, E-caderina e $\beta$-catenina foram registrados a partir de um fotomicroscópio (Axioskop2 plus, marca ZEISS).

\subsection{Questões Éticas}

Este estudo foi aprovado pela Comissão de Ética em Pesquisa (CEP) do Hospital do Câncer AC Camargo, em reunião de 29 de abril de 2003, Projeto de Pesquisa n $n^{\circ}$ 497/03. 
5 RESULTADOS 


\section{RESULTADOS}

\subsection{Casuística}

Os carcinomas escamosos basalóides e os carcinomas espinocelulares bem, moderadamente e pouco diferenciados de boca utilizados neste estudo constituem parte do banco de dados do Departamento de Cirurgia de Cabeça e Pescoço e Otorrinolaringologia e do Departamento de Anatomia Patológica do Hospital do Câncer no período de 1970 a 2000 (Tabela 2). Os CEBs e os CEC/PDs foram previamente analisados por GÓES ${ }^{32}$, sendo os CEC/BDs pareados pela localização e estadiamento clínico com os carcinomas espinocelulares pouco diferenciados.

TABELA 2 - Distribuição dos carcinomas escamosos basalóides, carcinomas espinocelulares pouco diferenciados e carcinomas espinocelulares bem a moderadamente diferenciados de boca, quanto aos critérios de inclusão estabelecidos. Hospital do Câncer, São Paulo, 1970 a 2000

\begin{tabular}{lcc}
\hline \multicolumn{1}{c}{ GRUPO } & N & \% \\
\hline Carcinoma Escamoso Basalóide & 17 & 23,9 \\
Carcinoma Espinocelular Pouco Diferenciado & 26 & 36,6 \\
Carcinoma Espinocelular Bem/Moderadamente Diferenciado & 28 & 39,5 \\
\hline TOTAL & 71 & 100,0 \\
\hline \hline
\end{tabular}




\subsection{Caracterização Demográfica e Clínica da População de Estudo}

A análise dos 17 pacientes com carcinoma escamoso basalóide, dos 26 com carcinoma espinocelular pouco diferenciado e dos 28 com carcinoma espinocelular bem a moderadamente diferenciado revelou um predomínio de pacientes do gênero masculino e da raça branca, para todos os grupos (Tabela 3).

No grupo CEB, a idade mínima observada foi de 43 anos e a máxima 77 anos (idade média 59,5 e desvio padrão 9,34). A idade dos pacientes dos grupos CEC/PD e CEC/BD foi, respectivamente, de 33 anos a mínima e a máxima 78 anos (idade média 58,4 e desvio padrão 12,08) e de 28 anos a mínima e a máxima de 95 anos (idade média 56,7 e desvio padrão 13,23). Uma elevada prevalência de pacientes tabagistas e etilistas foi observada nos três grupos analisados, como pode ser visualizado na Tabela 3.

A análise clínica dos pacientes dos grupos CEB, CEC/PD e CEC/BD revelou que, no momento do diagnóstico, os pacientes apresentaram estádios clínicos avançados (III-IV). Quanto ao estadiamento clínico T, no grupo CEB 70,6\% dos pacientes apresentaram tumores classificados como T3-4, nos grupos CEC/PD e CEC/BD, 76,9\% e 67,9\% dos tumores eram, respectivamente, também T3-4. Verificou-se que 70,6\% dos pacientes do grupo CEB, 69,2\% do grupo $\mathrm{CEC} / \mathrm{PD}$ e $67,9 \%$ do grupo $\mathrm{CEC} / \mathrm{BD}$ apresentaram linfonodos regionais clinicamente palpáveis no momento do diagnóstico (Tabela 4). 
TABELA 3 - Distribuição das características demográficas e da história clínica dos pacientes com carcinoma escamoso basalóide, com carcinoma espinocelular pouco diferenciado e com carcinoma espinocelular bem a moderadamente diferenciado de boca. Hospital do Câncer, São Paulo, 1970 a 2000

\begin{tabular}{|c|c|c|c|c|c|c|c|}
\hline \multirow{3}{*}{ Variável } & \multicolumn{7}{|c|}{ GRUPOS } \\
\hline & \multicolumn{2}{|c|}{ CEB } & \multicolumn{2}{|c|}{ CEC/PD } & \multicolumn{2}{|c|}{ CEC/BD } & \multirow{2}{*}{$p^{*}$} \\
\hline & $\mathrm{N}$ & $\%$ & $\mathrm{~N}$ & $\%$ & $\mathrm{~N}$ & $\%$ & \\
\hline \multicolumn{8}{|l|}{ Gênero } \\
\hline Masculino & 15 & 88,2 & 25 & 96,1 & 26 & 92,9 & \multirow{2}{*}{ NA } \\
\hline Feminino & 2 & 11,8 & 1 & 3,9 & 2 & 7,1 & \\
\hline \multicolumn{8}{|l|}{ Raça } \\
\hline Branca & 15 & 88,2 & 22 & 84,6 & 24 & 85,7 & \multirow{2}{*}{ NA } \\
\hline Não Branca & 2 & 11,8 & 4 & 15,4 & 4 & 14,3 & \\
\hline \multicolumn{8}{|l|}{ Idade } \\
\hline$\leq 59$ anos & 7 & 41,2 & 15 & 57,7 & 16 & 57,1 & \multirow{2}{*}{0,504} \\
\hline$>59$ anos & 10 & 58,8 & 11 & 42,3 & 12 & 42,9 & \\
\hline \multicolumn{8}{|l|}{ Tabagismo $^{\#}$} \\
\hline Não & 2 & 14,3 & 2 & 8,3 & 3 & 12,0 & \multirow{2}{*}{ NA } \\
\hline Sim & 12 & 85,7 & 22 & 91,7 & 22 & 88,0 & \\
\hline \multicolumn{8}{|l|}{ Etilismo $^{\#}$} \\
\hline Não & 3 & 23,1 & 3 & 12,5 & 3 & 12,0 & \multirow{2}{*}{ NA } \\
\hline Sim & 10 & 76,9 & 21 & 87,5 & 22 & 88,0 & \\
\hline TOTAL & 17 & 100,0 & 26 & 100,0 & 28 & 100,0 & \\
\hline
\end{tabular}

CEB: Carcinoma Escamoso Basalóide, CEC/PD: Carcinoma Espinocelular Pouco Diferenciado e CEC/BD: Carcinoma Espinocelular Bem a Moderadamente Diferenciado $p^{*}$ : valor obtido pelo teste do qui-quadrado considerando-se nível de significância de 5\% \#: excluídos os pacientes com informações ignoradas

NA: não se aplica

A localização mais freqüente do CEB foi no soalho bucal e a predominância de CEC em ambos os grupos foi na área retromolar/gengiva inferior. Clinicamente, $41,2 \%$ dos CEBs apresentaram aspecto ulcerovegetante e 58,8\% aspecto ulceroinfiltrativo. Nos grupos CECs, para os tumores pouco diferenciados, 30,8\% apresentavam aspecto clínico ulcerovegetante e $69,2 \%$ ulceroinfiltrativo, enquanto que nos tumores bem a moderadamente diferenciados, 10,7\% eram ulcerovegetantes e 89,3\% ulceroinfiltrativos (Tabela 4). 
TABELA 4 - Distribuição das características clínicas dos pacientes com carcinoma escamoso basalóide, com carcinoma espinocelular pouco diferenciado e com carcinoma espinocelular bem a moderadamente diferenciado de boca. Hospital do Câncer, São Paulo, 1970 a 2000

\begin{tabular}{|c|c|c|c|c|c|c|c|}
\hline \multirow{3}{*}{ Variável } & \multicolumn{7}{|c|}{ GRUPOS } \\
\hline & \multicolumn{2}{|c|}{ CEB } & \multicolumn{2}{|c|}{ CEC/PD } & \multicolumn{2}{|c|}{$\mathbf{C E C} / \mathrm{BD}$} & \multirow{2}{*}{$p^{*}$} \\
\hline & $\mathrm{N}$ & $\%$ & $\mathrm{~N}$ & $\%$ & $\mathrm{~N}$ & $\%$ & \\
\hline \multicolumn{8}{|l|}{$\mathbf{T}$} \\
\hline T1-2 & 5 & 29,4 & 6 & 23,1 & 9 & 32,1 & \multirow{2}{*}{0,754} \\
\hline T3-4 & 12 & 70,6 & 20 & 76,9 & 19 & 67,9 & \\
\hline \multicolumn{8}{|l|}{$\mathbf{N}$} \\
\hline N0 & 5 & 29,4 & 8 & 30,8 & 9 & 32,1 & \multirow{2}{*}{0,981} \\
\hline $\mathrm{N}+$ & 12 & 70,6 & 18 & 69,2 & 19 & 67,9 & \\
\hline \multicolumn{8}{|l|}{ Estádio clínico } \\
\hline I-II & 3 & 17,6 & 5 & 19,2 & 6 & 21,4 & \multirow{2}{*}{ NA } \\
\hline III-IV & 14 & 82,4 & 21 & 80,8 & 22 & 78,6 & \\
\hline \multicolumn{8}{|l|}{ Localização } \\
\hline Língua & 3 & 17,7 & 5 & 19,3 & 7 & 25,0 & \multirow{3}{*}{ NA } \\
\hline Soalho & 10 & 58,8 & 9 & 34,6 & 8 & 28,6 & \\
\hline Retromolar/gengiva & 4 & 23,5 & 12 & 46,1 & 13 & 46,4 & \\
\hline \multicolumn{8}{|l|}{ Tipo de lesão } \\
\hline Ulcerovegetante & 7 & 41,2 & 8 & 30,8 & 3 & 10,7 & \multirow{2}{*}{ NA } \\
\hline Ulceroinfiltrativa & 10 & 58,8 & 18 & 69,2 & 25 & 89,3 & \\
\hline TOTAL & 17 & 100,0 & 26 & 100,0 & 28 & 100,0 & \\
\hline
\end{tabular}

CEB: Carcinoma Escamoso Basalóide, CEC/PD: Carcinoma Espinocelular Pouco Diferenciado e CEC/BD: Carcinoma Espinocelular Bem a Moderadamente Diferenciado $p^{*}$ : valor obtido pelo teste do qui-quadrado considerando-se nível de significância de $5 \%$ NA: não se aplica

Todos os pacientes incluídos neste estudo foram submetidos à cirurgia como tratamento inicial, de acordo com os critérios de inclusão. O esvaziamento cervical foi realizado em todos os pacientes dos grupos CEB e CEC/PD. Em apenas um dos pacientes $(3,6 \%)$ do grupo $\mathrm{CEC} / \mathrm{BD}$ não foi realizado o esvaziamento cervical. No grupo CEB, um total de $53,0 \%$ dos pacientes foi submetido ao esvaziamento cervical ipsilateral, enquanto que, nos 
grupos $\mathrm{CEC} / \mathrm{PD}$ e $\mathrm{CEC} / \mathrm{BD}, 73,0$ e 78,6\% dos pacientes se submeteram, respectivamente, ao mesmo tipo de esvaziamento linfonodal (Tabela 5).

A radioterapia pós-operatória complementar foi realizada em $88,2 \%$ dos pacientes com $\mathrm{CEB}$, em $84,6 \%$ dos pacientes com $\mathrm{CEC} / \mathrm{PD}$ e em $64,3 \%$ dos pacientes com CEC/BD. Apenas $17,7 \%$ dos pacientes com CEB, 26,9\% com CEC/PD e 17,9\% com CEC/BD foram submetidos à quimioterapia pós-operatória complementar (Tabela 5).

Quanto à evolução clínica dos pacientes, a recidiva local foi observada com maior freqüência no grupo CEC/PD (38,5\% dos pacientes) quando comparado aos grupos CEB (17,7\% dos pacientes) e CEC/BD (21,4\% dos pacientes). O período de seguimento dos pacientes variou de 1,5-187 meses (mediana 23 meses) para o grupo CEC/PD, de 3,6-168 meses (mediana 52 meses) para o grupo CEB e de 0,36-322 meses (mediana 21 meses) para o grupo CEC/BD (Tabela 5).

A recidiva regional foi menor nos pacientes do grupo CEC/PD $(19,2 \%)$ quando comparada aos pacientes do grupo CEB $(29,4 \%)$ e CEC/BD $(28,6 \%)$. O desenvolvimento de metástases a distância foi mais freqüente no grupo CEB e não ocorreu em nenhum paciente do grupo CEC/BD (Tabela 5). O pulmão foi o sítio mais acometido pelas metástases do carcinoma escamoso basalóide e do carcinoma espinocelular pouco diferenciado.

Constatou-se o desenvolvimento de um segundo tumor primário em 17,7\% dos pacientes do grupo CEB e em 15,4\% do grupo CEC/PD. Nenhum paciente do grupo CEC/BD desenvolveu segundo tumor primário (Tabela 5). 
TABELA 5 - Distribuição das características clínicas dos pacientes com carcinoma escamoso basalóide, com carcinoma espinocelular pouco diferenciado e com carcinoma espinocelular bem a moderadamente diferenciado de boca. Hospital do Câncer, São Paulo, 1970 a 2000

\begin{tabular}{|c|c|c|c|c|c|c|c|}
\hline \multirow{3}{*}{ Variável } & \multicolumn{7}{|c|}{ GRUPOS } \\
\hline & \multicolumn{2}{|c|}{ CEB } & \multicolumn{2}{|c|}{ CEC/PD } & \multicolumn{2}{|c|}{ CEC/BD } & \multirow{2}{*}{$p^{*}$} \\
\hline & $\mathrm{N}$ & $\%$ & $\mathrm{~N}$ & $\%$ & $\mathrm{~N}$ & $\%$ & \\
\hline \multicolumn{8}{|c|}{ Cirurgia/esvaziamento } \\
\hline Não esvaziado & 0 & 0,0 & 0 & 0,0 & 1 & 3,6 & \multirow{3}{*}{ NA } \\
\hline Ipsilateral & 9 & 53,0 & 19 & 73,0 & 22 & 78,6 & \\
\hline Bilateral & 8 & 47,0 & 7 & 27,0 & 5 & 17,8 & \\
\hline \multicolumn{8}{|l|}{ Radioterapia } \\
\hline Não & 2 & 11,8 & 4 & 15,4 & 10 & 35,7 & \multirow{2}{*}{ NA } \\
\hline Sim & 15 & 88,2 & 22 & 84,6 & 18 & 64,3 & \\
\hline \multicolumn{8}{|l|}{ Quimioterapia } \\
\hline Não & 14 & 82,3 & 19 & 73,1 & 23 & 82,1 & \multirow{2}{*}{ NA } \\
\hline Sim & 3 & 17,7 & 7 & 26,9 & 5 & 17,9 & \\
\hline \multicolumn{8}{|l|}{ Recidiva local } \\
\hline Não & 14 & 82,3 & 16 & 61,5 & 22 & 78,6 & \multirow{2}{*}{0,230} \\
\hline Sim & 3 & 17,7 & 10 & 38,5 & 6 & 21,4 & \\
\hline \multicolumn{8}{|l|}{ Recidiva regional } \\
\hline Não & 12 & 70,6 & 21 & 80,8 & 20 & 71,4 & \multirow{2}{*}{ NA } \\
\hline Sim & 5 & 29,4 & 5 & 19,2 & 8 & 28,6 & \\
\hline \multicolumn{8}{|c|}{ Metástase à distância } \\
\hline Não & 13 & 76,5 & 23 & 88,5 & 28 & 100,0 & \multirow{2}{*}{ NA } \\
\hline Sim & 4 & 23,5 & 3 & 11,5 & 0 & 0,0 & \\
\hline \multicolumn{8}{|l|}{ Segundo tumor } \\
\hline Não & 14 & 82,3 & 22 & 84,6 & 28 & 100,0 & \multirow{2}{*}{ NA } \\
\hline Sim & 3 & 17,7 & 4 & 15,4 & 0 & 0,0 & \\
\hline TOTAL & 17 & 100,0 & 26 & 100,0 & 28 & 100,0 & \\
\hline
\end{tabular}

CEB: Carcinoma Escamoso Basalóide, CEC/PD: Carcinoma Espinocelular Pouco Diferenciado e CEC/BD: Carcinoma Espinocelular Bem a Moderadamente Diferenciado $p^{*}$ : valor obtido pelo teste do qui-quadrado considerando-se nível de significância de $5 \%$ NA: não se aplica 


\subsection{Análise Morfológica dos Carcinomas}

\subsubsection{Carcinoma Escamoso Basalóide}

As características morfológicas do carcinoma escamoso basalóide foram previamente analisadas por GÓES ${ }^{32}$ e confirmadas no presente estudo. Em 52,9\% dos CEBs, observou-se uma continuidade destes tumores com a mucosa bucal, sendo o predomínio das células basalóides (mais de $80 \%$ do componente tumoral) um aspecto freqüentemente observado.

Morfologicamente, o padrão sólido ou também denominado lobular foi observado em 47,1\% dos espécimes e o padrão trabecular em 29,4\% (Figura 1). Em quatro espécimes $(23,5 \%)$ os padrões sólido e trabecular estavam presentes simultaneamente (Tabela 6). Os padrões morfológicos tubular e cribiforme não foram encontrados na amostra estudada.

As características peculiares do carcinoma escamoso basalóide como a disposição em paliçada das células periféricas das ilhotas tumorais, a ausência de pontes intercelulares e a presença de necrose por coagulação central (comedonecrose) foram identificadas na maioria dos tumores (Figura 2).

Em 88,2\% dos espécimes foram observados espaços císticos, entretanto em apenas $20,0 \%$ seu conteúdo foi PAS positivo. Estruturas ductiformes estavam presentes em 23,5\% dos carcinomas escamosos basalóides (Tabela 6 e Figura 3). A disjunção entre o epitélio tumoral e o tecido conjuntivo adjacente foi observada em 76,5\% dos carcinomas escamosos basalóides (Figura 1). Em apenas 29,4\% dos tumores notou-se uma hialinização do tecido conjuntivo peritumoral (Tabela 6 e Figura 1). O componente escamoso associado ao basalóide esteve presente de forma intercalada em 76,5\% dos espécimes caracterizando-se principalmente pela presença de pérolas córneas e disqueratoses (Tabela 6 e Figura 4). 
TABELA 6 - Distribuição das características morfológicas do carcinoma escamoso basalóide. Hospital do Câncer, São Paulo, 1970 a 2000

\begin{tabular}{|c|c|c|}
\hline \multirow{2}{*}{ Variável } & \multicolumn{2}{|c|}{ Carcinoma Escamoso Basalóide } \\
\hline & $\mathrm{N}$ & $\%$ \\
\hline \multicolumn{3}{|c|}{ Continuidade com a mucosa } \\
\hline Ausente & 6 & 35,3 \\
\hline Presente & 9 & 52,9 \\
\hline Não observada & 2 & 11,8 \\
\hline \multicolumn{3}{|l|}{ Morfologia tumoral } \\
\hline Sólido / lobular & 8 & 47,1 \\
\hline Trabecular & 5 & 29,4 \\
\hline Ambos & 4 & 23,5 \\
\hline \multicolumn{3}{|l|}{ Disposição em paliçada } \\
\hline Ausente & 4 & 23,5 \\
\hline Presente & 13 & 73,5 \\
\hline \multicolumn{3}{|c|}{ Pontes intercelulares células basalóides } \\
\hline Ausente & 16 & 94,1 \\
\hline Presente & 1 & 5,9 \\
\hline \multicolumn{3}{|l|}{ Espaços Císticos } \\
\hline Ausente & 2 & 11,8 \\
\hline Presente & 15 & 88,2 \\
\hline PAS $(+)$ & 3 & 20,0 \\
\hline \multicolumn{3}{|l|}{ Estruturas ductiformes } \\
\hline Ausente & 13 & 76,5 \\
\hline Presente & 4 & 23,5 \\
\hline PAS $(+)$ & - & - \\
\hline \multicolumn{3}{|c|}{ Disjunção tumor/conjuntivo } \\
\hline Ausente & 4 & 23,5 \\
\hline Presente & 13 & 76,5 \\
\hline \multicolumn{3}{|l|}{ Hialinização peritumoral } \\
\hline Ausente & 12 & 70,6 \\
\hline Presente & 5 & 29,4 \\
\hline \multicolumn{3}{|c|}{ Necrose central - comedonecrose } \\
\hline Ausente & 1 & 5,9 \\
\hline Presente & 16 & 94,1 \\
\hline \multicolumn{3}{|c|}{ Componente escamoso associado } \\
\hline Ausente & 3 & 17,3 \\
\hline Intercalado & 13 & 76,5 \\
\hline Adjacente & 1 & 5,9 \\
\hline TOTAL & 17 & 100,0 \\
\hline
\end{tabular}



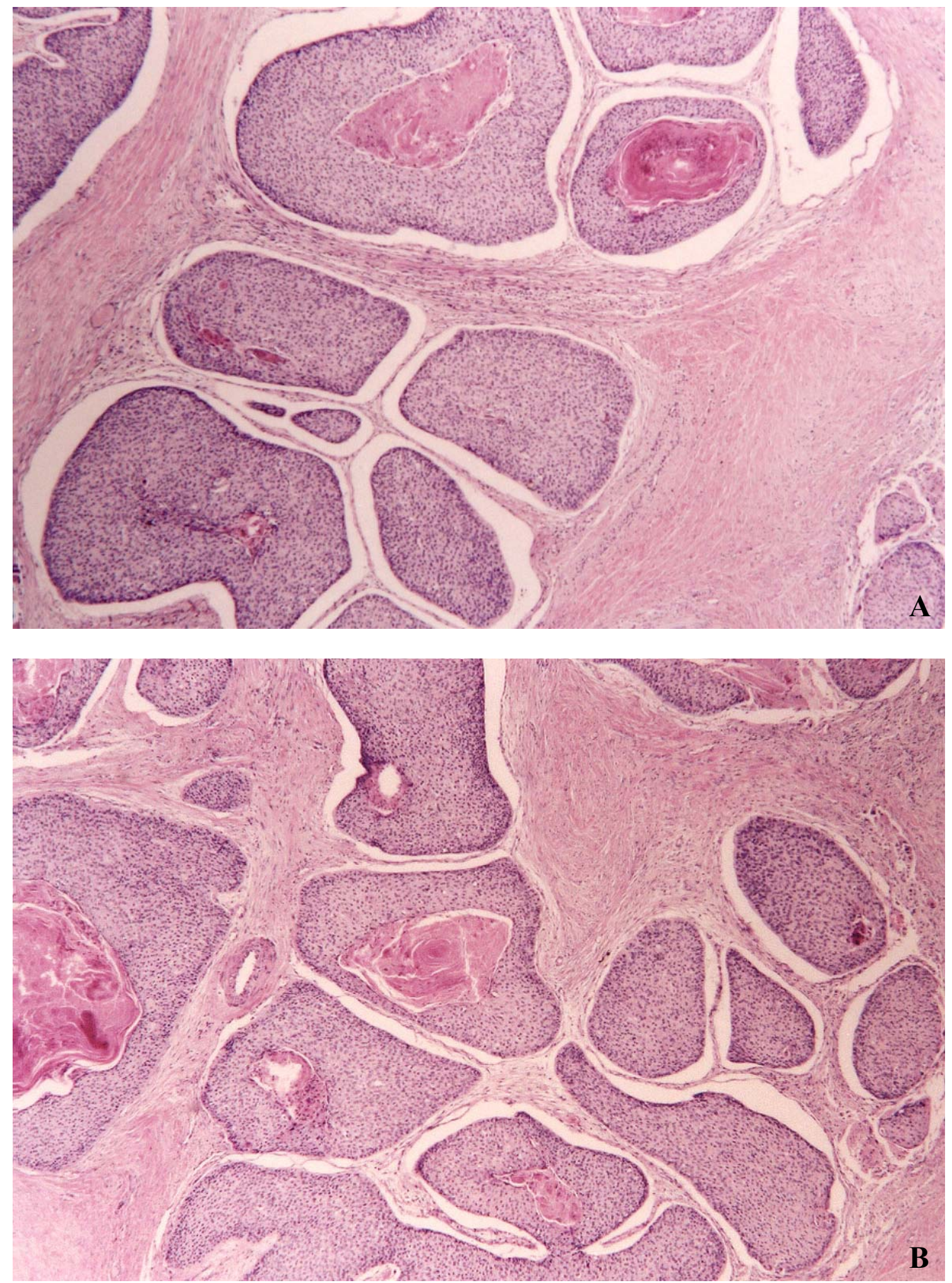

FIGURA 1- CEB apresentando padrão sólido ou lobular com disjunção entre o epitélio tumoral e o tecido conjuntivo adjacente. Observar também hialinização do tecido conjuntivo adjacente (A e B). ( $\mathrm{HE}$, aumento original A e $\mathrm{B}=50 \mathrm{X}$ ) 

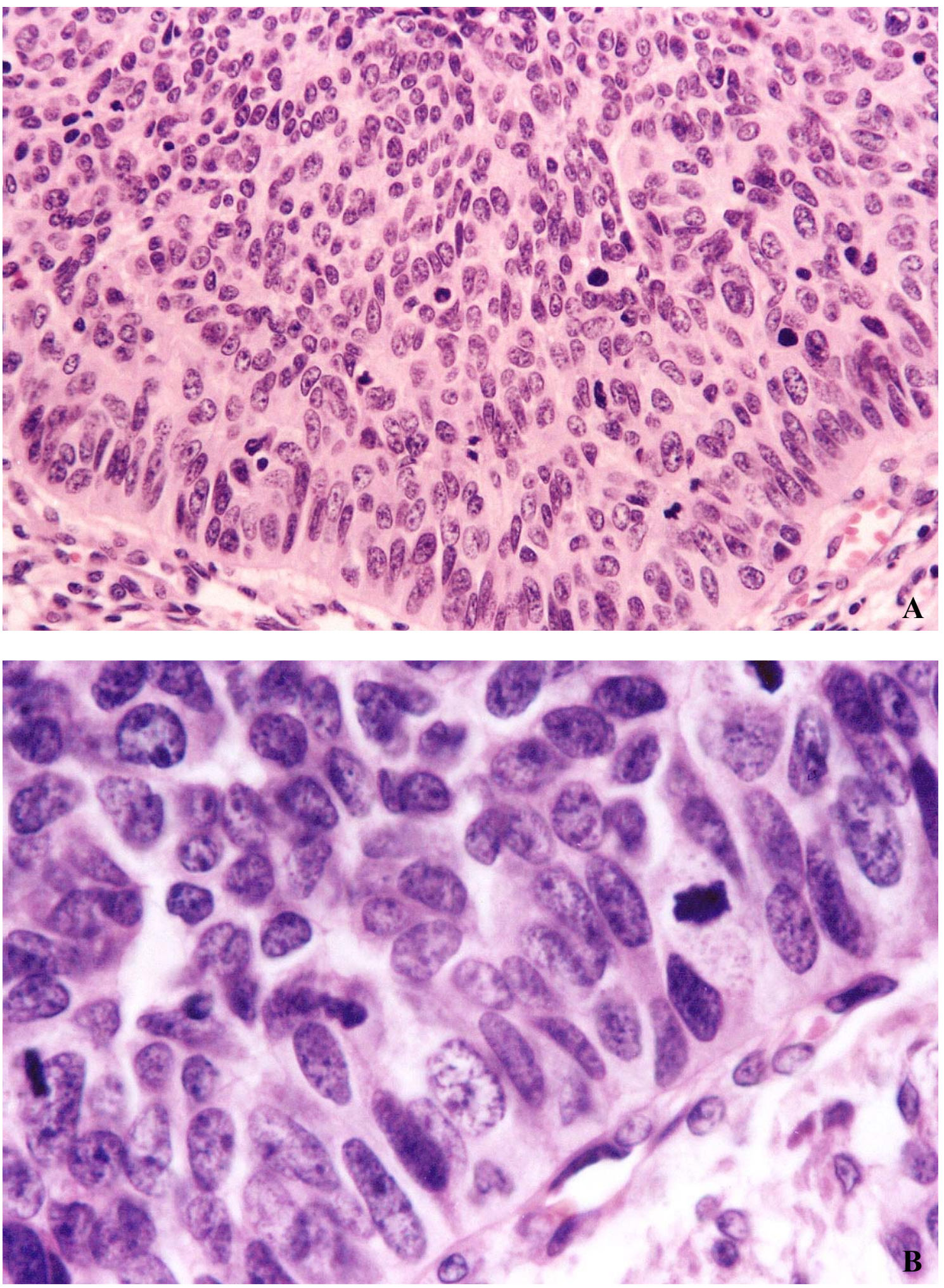

FIGURA 2- Disposição em paliçada das células periféricas das ilhotas tumorais no CEB. Observar a presença de inúmeras figuras de mitoses atípicas (A e B). (HE, aumento original $\mathrm{A}=400 \mathrm{X}$ e $\mathrm{B}=1000 \mathrm{X}$ ) 

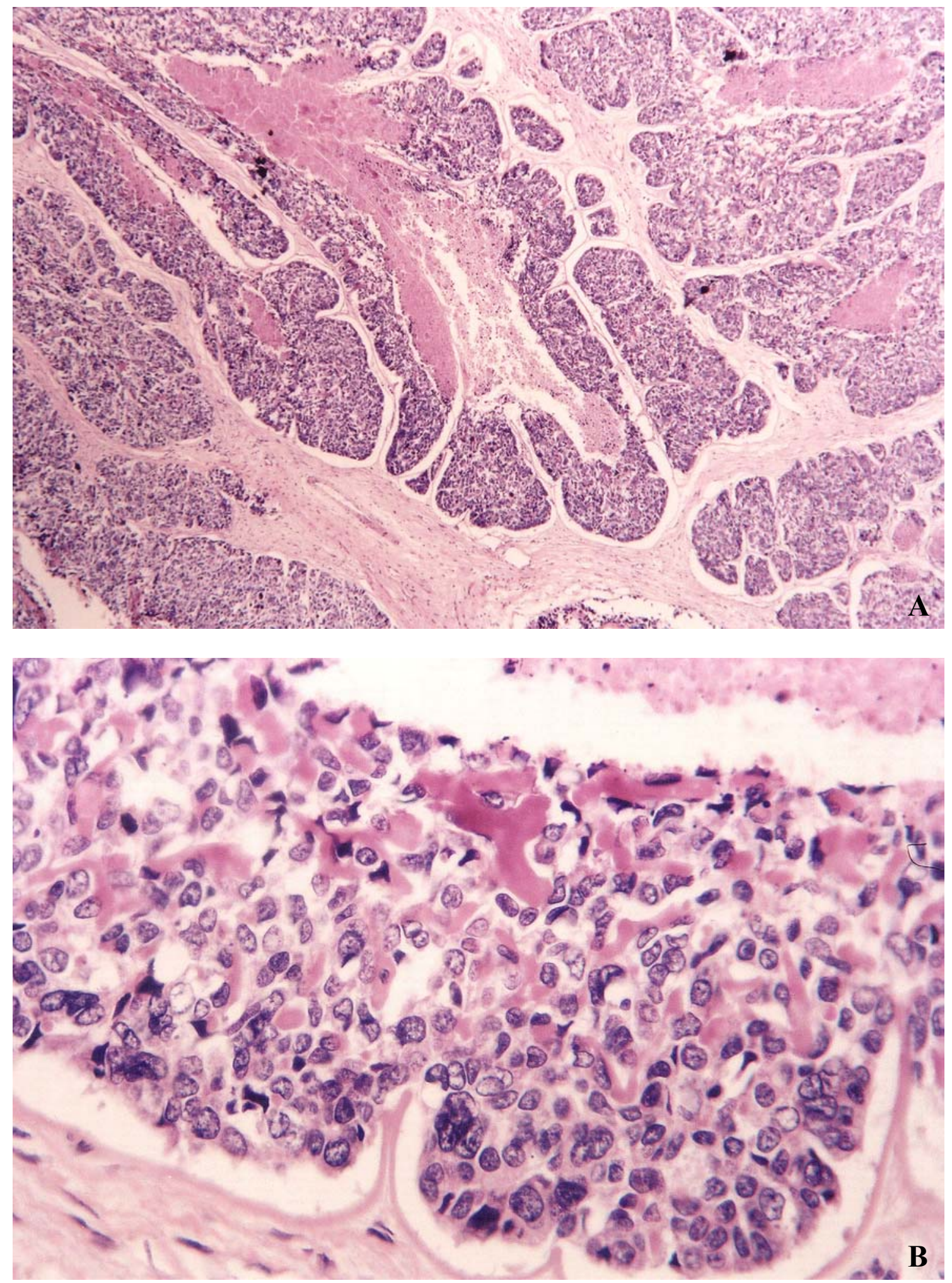

FIGURA 3- CEB apresentando espaços císticos PAS positivos além de estruturas ductiformes (A e B). (HE, aumento original $A=50 \mathrm{X}$ e $\mathrm{B}=400 \mathrm{X})$ 

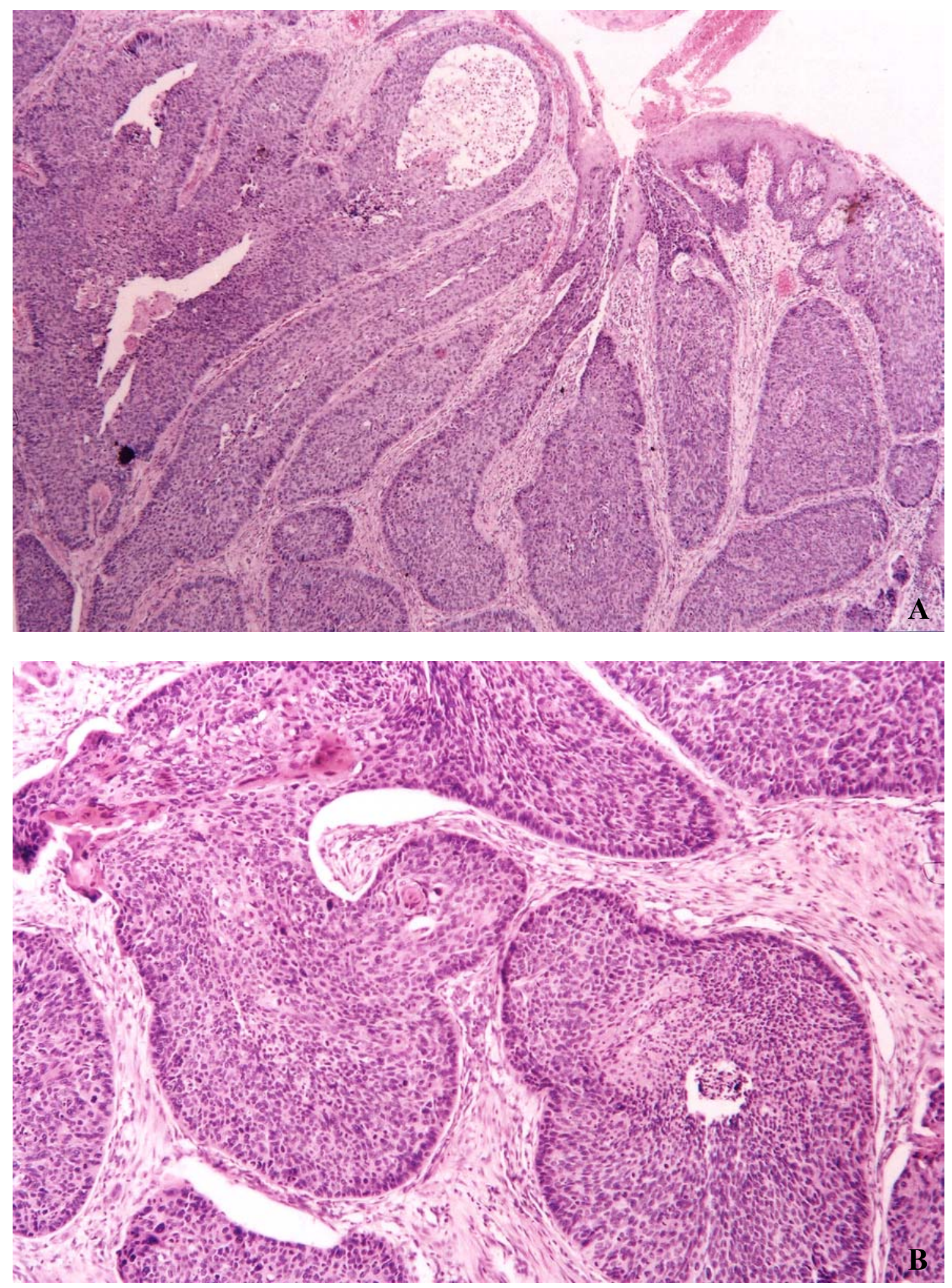

FIGURA 4- CEB em continuidade com a mucosa bucal (A). Componente escamoso associado ao CEB apresentando áreas focais de queratinização (B). (HE, aumento original $\mathrm{A}=50 \mathrm{X}$ e $\mathrm{B}=100 \mathrm{X}$ ) 


\subsubsection{Carcinomas Espinocelulares}

A freqüência da distribuição das características microscópicas dos dois grupos de carcinomas espinocelulares de boca, obtidas pelo índice de malignidade proposto por BRYNE et al. ${ }^{21}$ pode ser visualizada na Tabela 7.

As variáveis grau de queratinização, pleomorfismo nuclear, número de mitoses, e resposta do hospedeiro, cada uma composta inicialmente por quatro categorias (graus 1, 2, 3 ou 4) foram posteriormente agrupadas em duas categorias (graus 1 e 2 versus graus 3 e 4). Assim sendo, o grau de queratinização foi considerado alto (graus 1 ou 2) ou baixo (graus 3 ou 4). O pleomorfismo nuclear e o número de mitoses foram considerados baixo (graus $1 \mathrm{ou}$ 2) ou alto (graus 3 ou 4). Para o padrão de invasão, analisamos o padrão compressivo (grau 1) confrontando-o com os padrões infiltrativos (graus 2, 3 ou 4). A resposta do hospedeiro determinada pela intensidade do infiltrado inflamatório mononuclear na área do front de invasão tumoral foi considerada intensa (graus 1 ou 2) ou discreta (graus 3 ou 4).

O índice total de malignidade em nossa amostra variou de 5 a 16 . Os carcinomas espinocelulares com valores maiores que dez foram considerados mais indiferenciados, com comportamento biológico mais agressivo, quando comparados com aqueles que apresentavam valores iguais ou menores que dez para o índice total de malignidade.

Microscopicamente, os carcinomas espinocelulares bem a moderadamente diferenciados $(\mathrm{CEC} / \mathrm{BD})$ apresentaram características típicas representadas por predominante queratinização tumoral, baixo pleomorfismo nuclear, poucas mitoses e intenso infiltrado inflamatório mononuclear. Por outro lado, no grupo de carcinomas espinocelulares pouco diferenciados, os aspectos que mais se destacaram foram a discreta ou ausente queratinização 
associada a um maior pleomorfismo nuclear e um padrão infiltrativo na região do front de invasão tumoral.

Como pode ser observado na Tabela $7,96,4 \%$ dos tumores do grupo CEC/BD apresentaram uma alta queratinização tumoral, estatisticamente significativa $(p<0,001)$, quando comparados àqueles do grupo $\mathrm{CEC} / \mathrm{PD}$ (Figura 5). A maior freqüência de pleomorfismo nuclear $(42,3 \%)$ bem como um maior número de mitoses $(46,2 \%)$ foram observados nos tumores do grupo CEC/PD (Tabela 7 e Figura 6).

Em mais de $80 \%$ dos carcinomas espinocelulares de ambos os grupos, o front de invasão tumoral apresentou um predomínio do padrão de invasão infiltrativo, caracterizado por células epiteliais neoplásicas dispostas em cordões grossos, cordões finos e/ ou células isoladas (Figura 7). Um intenso infiltrado inflamatório (Tabela 7) estava presente em 73,0\% dos carcinomas do grupo CEC/PD e em $82,1 \%$ dos carcinomas do grupo CEC/BD, entretanto, estes valores não foram comparativamente significativos $(\mathrm{p}=0,423)$.

Um maior índice total de malignidade $(\mathrm{p}<0,001)$ foi detectado nos tumores do grupo $\mathrm{CEC} / \mathrm{PD}$ quando comparado àqueles do grupo CEC/BD (Tabela 7), destacando-se que em mais de $90 \%$ dos tumores pouco diferenciados estes índices eram maiores que dez. 
TABELA 7 - Distribuição das características morfológicas do carcinoma espinocelular pouco diferenciado e do carcinoma espinocelular bem a moderadamente diferenciado. Hospital do Câncer, São Paulo, 1970 a 2000

\section{CARACTERÍSTICAS MICROSCÓPICAS}

\section{GRUPOS}

\section{CEC/PD}

$\mathrm{N} \quad \% \quad \mathrm{~N}^{\mathbf{C E C} / \mathbf{B D}}$

\section{Queratinização}

$\begin{array}{lccccc}\text { Alta } & 3 & 11,5 & 27 & 96,4 & <\mathbf{0 , 0 0 1} \\ \text { Baixa } & 23 & 88,5 & 1 & 3,6 & \end{array}$

Pleomorfismo nuclear

$\begin{array}{lccccc}\text { Baixo } & 15 & 57,7 & 27 & 96,4 & <\mathbf{0 , 0 0 1} \\ \text { Alto } & 11 & 42,3 & 1 & 3,6 & \end{array}$

Número de mitoses

$\begin{array}{lccccc}\text { Baixo } & 14 & 53,8 & 27 & 96,4 & <\mathbf{0 , 0 0 1} \\ \text { Alto } & 12 & 46,2 & 1 & 3,6 & \end{array}$

Padrão de invasão

Compressivo

$\begin{array}{lllll}4 & 15,4 & 5 & 17,9 & 0,808\end{array}$

Infiltrativo

22

84,6

23

82,1

\section{Infiltrado inflamatório}

$\begin{array}{lccccc}\text { Intenso } & 19 & 73,0 & 23 & 82,1 & 0,423 \\ \text { Discreto } & 7 & 27,0 & 5 & 17,9 & \end{array}$

Índice total de malignidade

\begin{tabular}{lccccc} 
Pouco agressivo $(\leq 10)$ & 2 & 7,7 & 24 & 85,7 & $<\mathbf{0 , 0 0 1}$ \\
Muito agressivo $(>10)$ & 24 & 92,3 & 4 & 14,3 & \\
\hline TOTAL & 26 & 100,0 & 28 & 100,00 & \\
\hline \hline
\end{tabular}

CEC/PD: Carcinoma Espinocelular Pouco Diferenciado e CEC/BD: Carcinoma Espinocelular Bem a Moderadamente Diferenciado $p^{*}=$ valor obtido pelo teste do qui-quadrado considerando-se nível de significância de 5\% 
Outras características microscópicas como a embolização angiolinfática, as infiltrações muscular, perineural e óssea, bem como o comprometimento das margens cirúrgicas, também foram analisados e comparados entre os grupos de carcinoma escamoso basalóide e de carcinomas espinocelulares de boca.

A embolização angiolinfática esteve presente em 29,4\% dos tumores do grupo CEB, em $27,0 \%$ do grupo CEC/PD e em 42,9\% do grupo CEC/BD. Em 82,3\% dos CEBs, a infiltração perineural estava ausente, sendo este valor estatisticamente significativo $(p=0,004)$ quando comparado aos dois grupos de CECs. A maior freqüência $(69,2 \%)$ de infiltração perineural foi observada no grupo CEC/PD (Tabela 8 e Figura 8).

Em mais de 70,0\% dos CEBs e CECs notou-se infiltração tumoral muscular (Tabela 8). A infiltração óssea foi identificada, respectivamente, em $36,4 \%, 53,3 \%$ e $35,3 \%$ dos tumores dos grupos $\mathrm{CEB}, \mathrm{CEC} / \mathrm{PD}$ e $\mathrm{CEC} / \mathrm{BD}$. As margens cirúrgicas apresentaram-se livres em 93,8\% dos carcinomas escamosos basalóides, em 81,0\% dos carcinomas espinocelulares pouco diferenciados e em $91,3 \%$ dos carcinomas espinocelulares bem a moderadamente diferenciados (Tabela 8).

O esvaziamento cervical foi realizado nos 17 pacientes com CEB. A presença de comprometimento linfonodal neste grupo foi confirmada, pela análise microscópica, em nove pacientes $(53,0 \%)$.

Nos portadores de carcinomas espinocelulares, o esvaziamento cervical foi realizado em 26 pacientes do grupo $\mathrm{CEC} / \mathrm{PD}$ e em 27 pacientes do grupo CEC/BD. O comprometimento linfonodal foi microscopicamente confirmado em $73,0 \%$ e em $44,4 \%$ dos pacientes dos grupos $\mathrm{CEC} / \mathrm{PD}$ e $\mathrm{CEC} / \mathrm{BD}$, respectivamente. 
TABELA 8 - Distribuição das infiltrações tumorais do carcinoma escamoso basalóide, do carcinoma espinocelular pouco diferenciado e do carcinoma espinocelular bem a moderadamente diferenciado de boca. Hospital do Câncer, São Paulo, 1970 a 2000

\begin{tabular}{|c|c|c|c|c|c|c|c|}
\hline \multirow{3}{*}{ Variável } & \multicolumn{7}{|c|}{ GRUPOS } \\
\hline & \multicolumn{2}{|c|}{ CEB } & \multicolumn{2}{|c|}{$\mathrm{CEC} / \mathrm{PD}$} & \multicolumn{2}{|c|}{ CEC/BD } & \multirow{2}{*}{$p^{*}$} \\
\hline & $\mathrm{N}$ & $\%$ & $\mathrm{~N}$ & $\%$ & $\mathrm{~N}$ & $\%$ & \\
\hline \multicolumn{8}{|c|}{ Embolização vascular } \\
\hline Ausente & 12 & 70,6 & 19 & 73,0 & 16 & 57,1 & \multirow{2}{*}{0,423} \\
\hline Presente & 5 & 29,4 & 7 & 27,0 & 12 & 42,9 & \\
\hline \multicolumn{8}{|c|}{ Infiltração perineural } \\
\hline Ausente & 14 & 82,3 & 8 & 30,8 & 13 & 46,4 & \multirow{2}{*}{$\mathbf{0 , 0 0 4}$} \\
\hline Presente & 3 & 17,7 & 18 & 69,2 & 15 & 53,6 & \\
\hline \multicolumn{8}{|c|}{ Infiltração muscular } \\
\hline Ausente & 5 & 29,4 & 7 & 26,9 & 7 & 25,0 & \multirow{2}{*}{0,949} \\
\hline Presente & 12 & 70,6 & 19 & 73,1 & 21 & 75,0 & \\
\hline \multicolumn{8}{|l|}{ Infiltração óssea ${ }^{\#}$} \\
\hline Ausente & 7 & 63,6 & 7 & 46,7 & 11 & 64,7 & \multirow{2}{*}{0,536} \\
\hline Presente & 4 & 36,4 & 8 & 53,3 & 6 & 35,3 & \\
\hline \multicolumn{8}{|c|}{ Margens cirúrgicas ${ }^{\#}$} \\
\hline Livres & 15 & 93,8 & 17 & 81,0 & 21 & 91,3 & \multirow{2}{*}{ NA } \\
\hline Comprometidas & 1 & 6,2 & 4 & 19,0 & 2 & 8,7 & \\
\hline TOTAL & 17 & 100,0 & 26 & 100,0 & 28 & 100,0 & \\
\hline
\end{tabular}

CEB: Carcinoma Escamoso Basalóide, CEC/PD: Carcinoma Espinocelular Pouco Diferenciado e CEC/BD: Carcinoma Espinocelular Bem a Moderadamente Diferenciado $p^{*}$ : valor obtido pelo teste do qui-quadrado considerando-se nível de significância de $5 \%$ \#: excluídos os pacientes com informações ignoradas

NA: não se aplica 

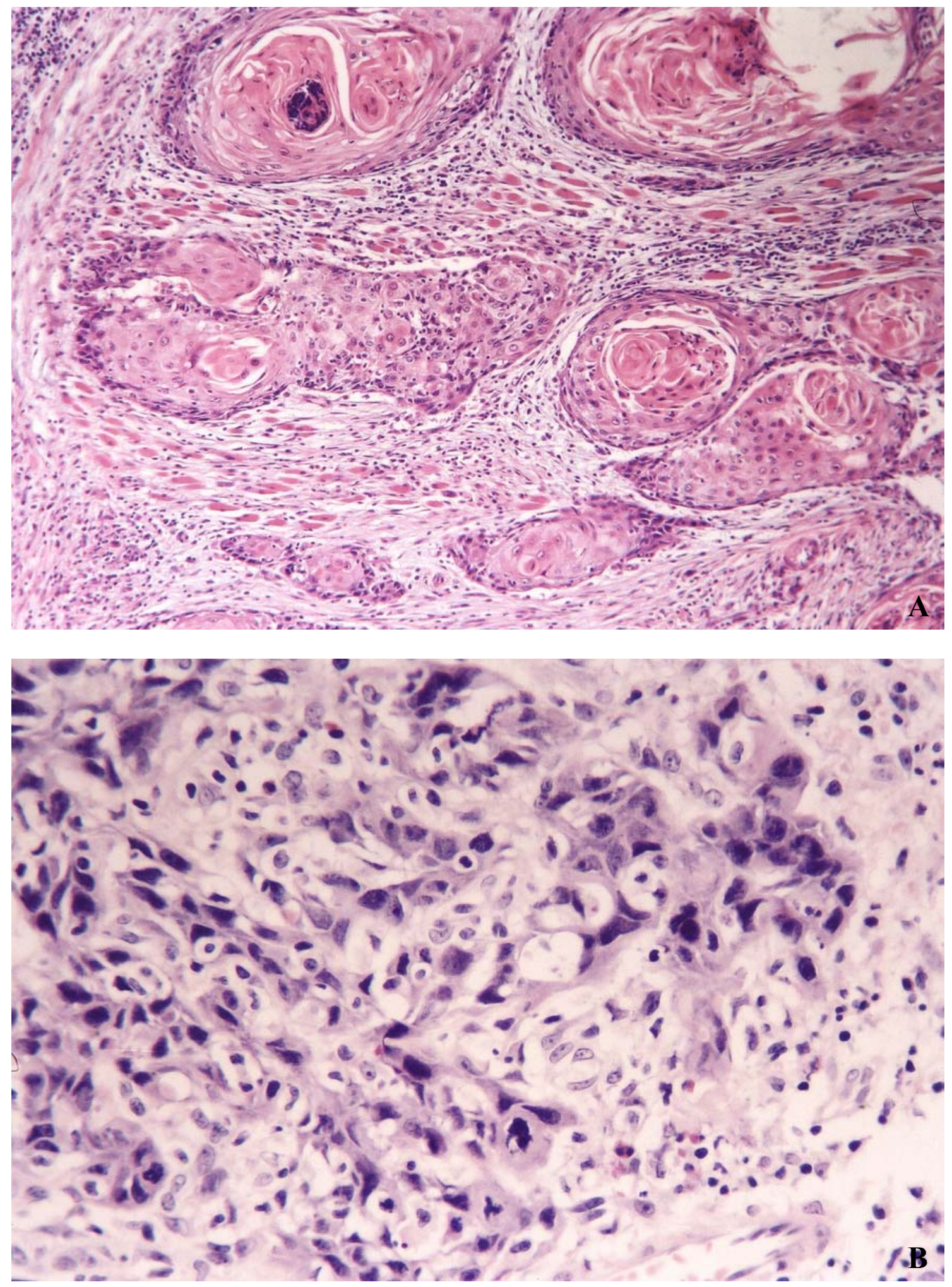

FIGURA 5- CEC/BD apresentando uma alta queratinização tumoral e infiltração muscular (A). Em B, observar ausência de queratinização no CEC/PD. (HE, aumento original $A=100 \mathrm{X}$ e $\mathrm{B}=400 \mathrm{X}$ ) 

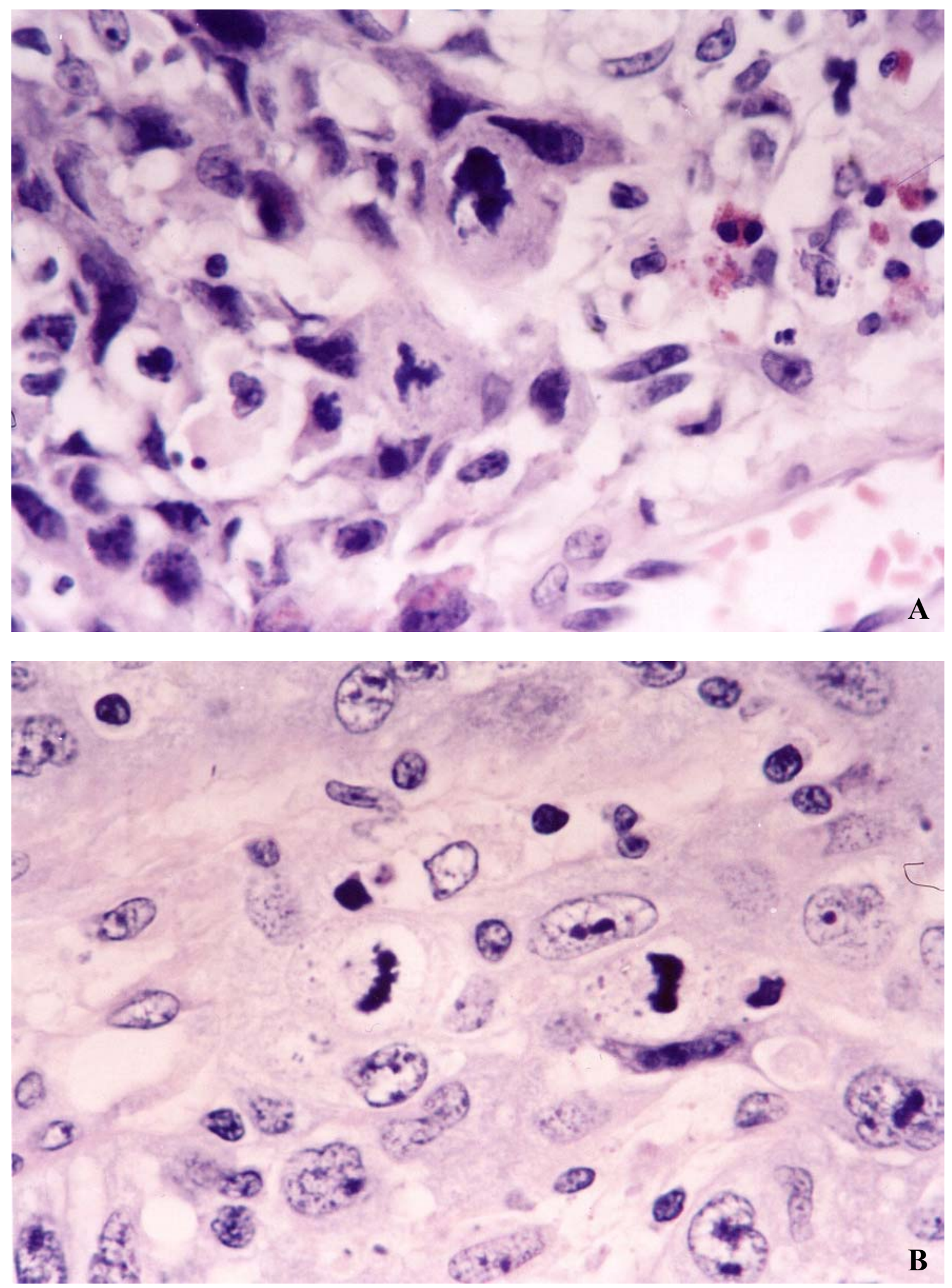

FIGURA 6- CEC/PD apresentando intenso pleomorfismo nuclear, hipercromatismo e numerosas figuras de mitoses atípicas $(\mathrm{A}$ e $\mathrm{B})$. ( $\mathrm{HE}$, aumento original $\mathrm{A}$ e $\mathrm{B}=1000 \mathrm{X})$ 

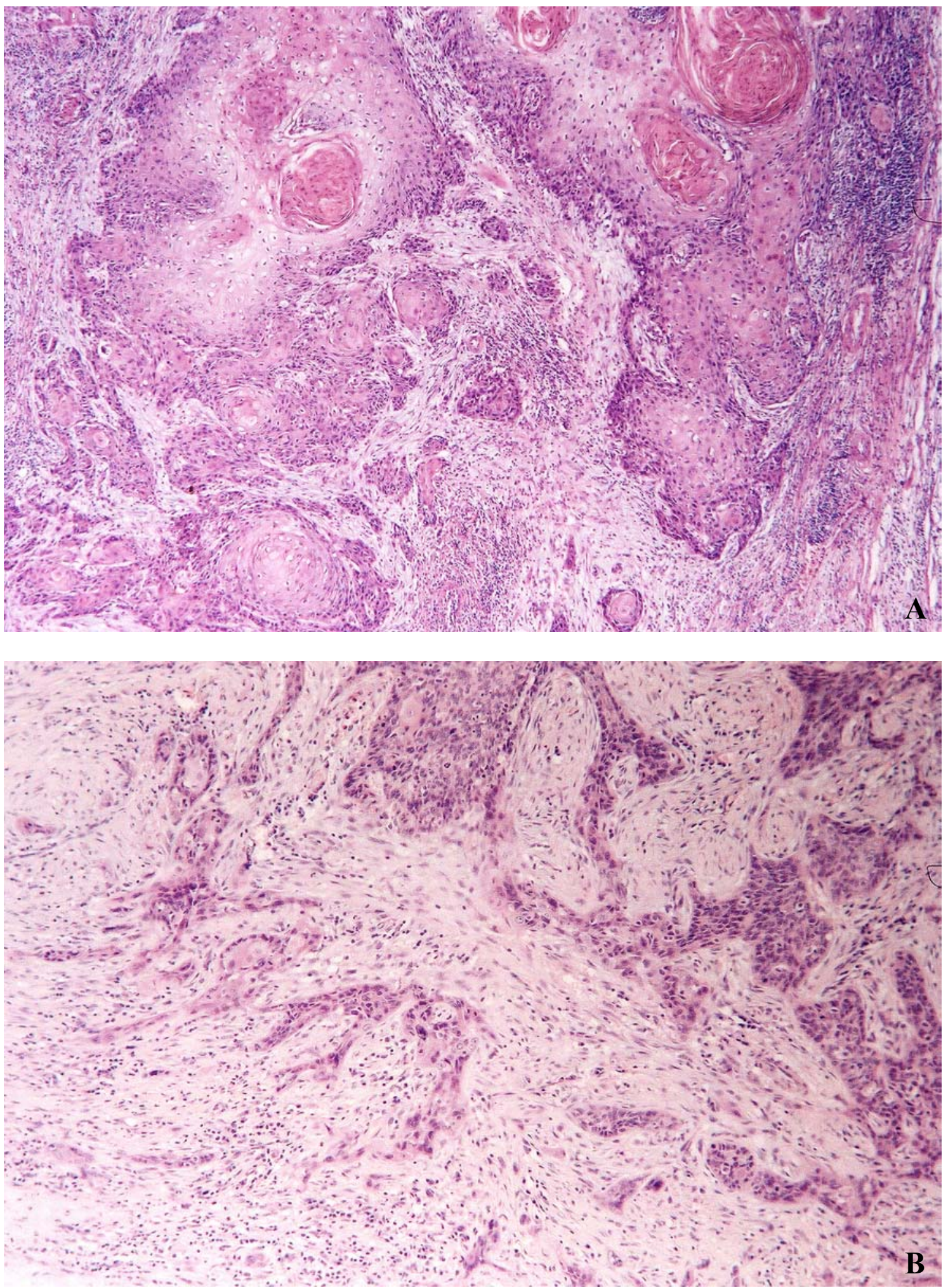

FIGURA 7- Padrão de invasão infiltrativo do $\mathrm{CEC} / \mathrm{BD}$ com células neoplásicas dispostas em cordões grossos (A). Em B, observar o padrão de invasão em cordões finos do $\mathrm{CEC} / \mathrm{PD}$ (HE, aumento original $\mathrm{A}=50 \mathrm{X}$ e $\mathrm{B}=100 \mathrm{X}$ ) 

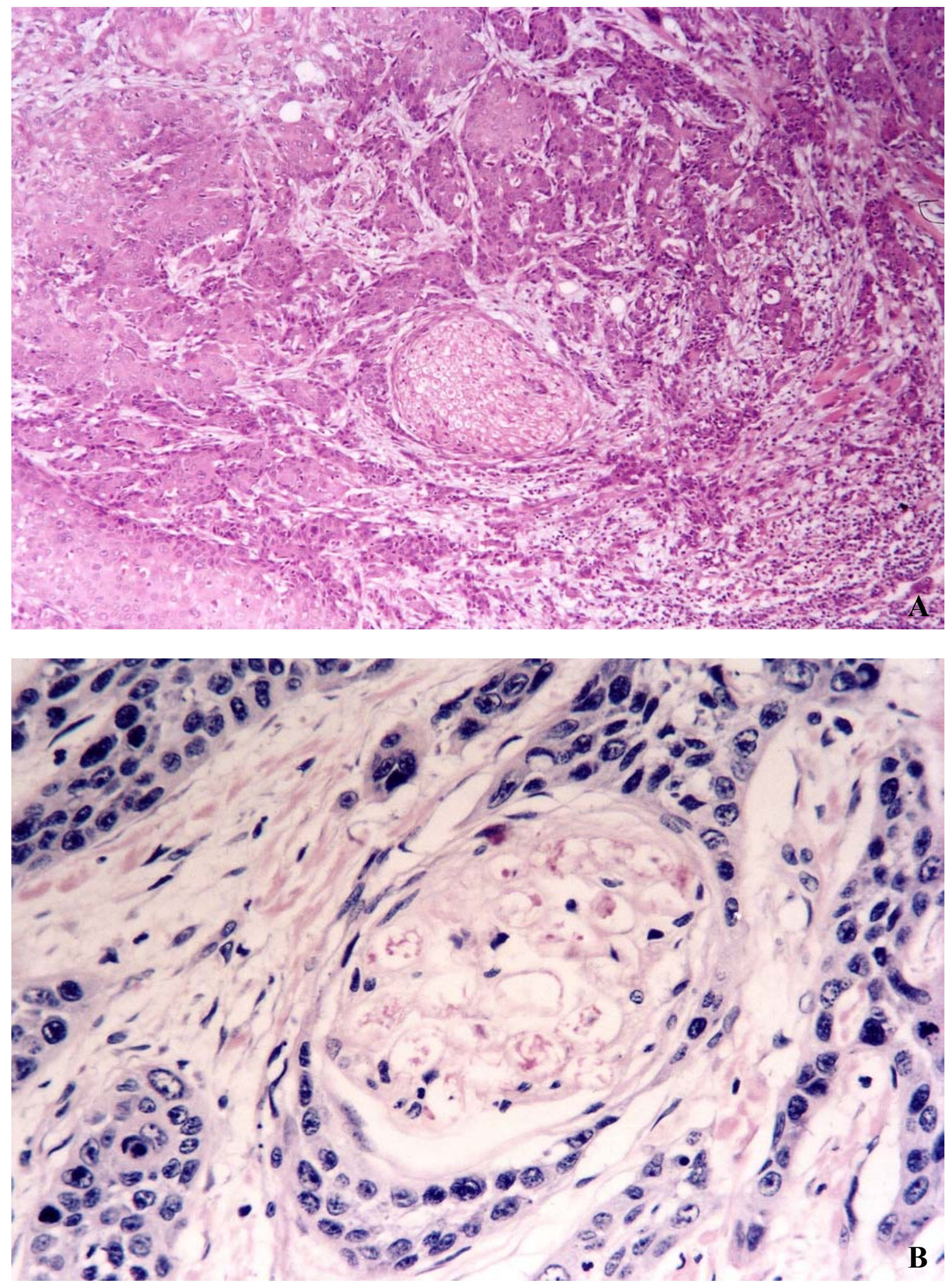

FIGURA 8- Infiltração perineural pelo $\mathrm{CEC} / \mathrm{BD}$ em $\mathrm{A}$ e pelo $\mathrm{CEC} / \mathrm{PD}$ em $\mathrm{B}$. (HE, aumento original $\mathrm{A}=100 \mathrm{X}$ e $\mathrm{B}=400 \mathrm{X}$ ) 


\subsection{Análise Imuno-histoquímica dos Carcinomas}

A partir dos valores obtidos pela marcação do anticorpo PCNA nos três grupos analisados (CEB, CEC/PD e CEC/BD), foi determinada a mediana e os resultados dicotomizados. As marcações para o anticorpo PCNA detectadas com valores menores ou iguais a $61,0 \%$ foram observadas em aproximadamente $57,0 \%$ dos carcinomas espinocelulares (CEC/PD e CEC/BD) e em 33,3\% dos carcinomas escamosos basalóides. A imunopositividade para o PCNA com valores superiores a $61,0 \%$ foi verificada em $66,7 \%$ dos carcinomas escamosos basalóides e em mais de 42,0\% de ambos os grupos de carcinomas espinocelulares (Tabela 9 e Figuras 9 e 10). Como pode ser observado na Tabela 9, não houve diferença estatisticamente significativa na expressão do PCNA entre os grupos analisados.

Com relação à molécula de adesão epitelial E-caderina, sua expressão foi detectada na mucosa bucal com padrão de normalidade sobrejacente à neoplasia (Figura 11A) e nas células tumorais tanto na membrana plasmática como no citoplasma. Uma forte expressão do anticorpo E-caderina foi demonstrada, predominantemente, na membrana plasmática de mais de $40,0 \%$ dos carcinomas espinocelulares bem a moderadamente diferenciados (Figura 11B e 12A). Para os grupos CEC/PD e CEB, uma forte positividade, principalmente citoplasmática, para a E-caderina foi detectada em apenas $19,2 \%$ e $11,8 \%$ dos tumores, respectivamente (Tabela 9 e Figura 12B).

A redução ou ausência de expressão de E-caderina foi observada em mais de $80 \%$ dos carcinomas dos grupos CEB (Figura 13B) e CEC/PD (Figura 12B) e em apenas 53,6\% daqueles do grupo CEC/BD (Tabela 9). Destaca-se ainda que, nos carcinomas escamosos basalóides, a expressão membranosa da E-caderina como ilustrado na Figura 13A foi observada em apenas alguns raros tumores. 
Assim como a E-caderina, a expressão de $\beta$-catenina foi detectada microscopicamente na membrana plasmática e no citoplasma das células tumorais. A fraca positividade para a $\beta$ catenina foi evidenciada em mais de $70,0 \%$ de ambos os grupos de carcinomas espinocelulares analisados (CEC/PD e CEC/BD) e em 58,8\% dos carcinomas escamosos basalóides de boca (Tabela 9).

A forte expressão do anticorpo $\beta$-catenina foi visualizada, respectivamente, em apenas 26,9\% e 20,8\% dos tumores dos grupos CEC/BD (Figura 14A) e CEC/PD (Figura 14B). Nos carcinomas escamosos basalóides, a expressão membranosa de $\beta$-catenina, ainda que irregular, foi detectada juntamente com a expressão citoplasmática em $41,2 \%$ dos espécimes (Tabela 9 e Figura 15).

Uma diferença estatisticamente significativa na expressão da E-caderina nas células epiteliais tumorais foi observada no grupo CEC/BD quando comparado aos grupos $\mathrm{CEB}$ e CEC/PD $(p=0,019)$, entretanto, em relação à expressão epitelial de $\beta$-catenina, nenhuma diferença estatisticamente significativa (Tabela 9) foi detectada entre os três diferentes grupos de carcinomas estudados.

A correlação dos anticorpos PCNA, E-caderina e $\beta$-catenina com algumas características clínicas e microscópicas estudadas pode ser observada nas Tabelas 10,11,12 e 13.

Como demonstrado na Tabela 13, a forte expressão de E-caderina foi estatisticamente significativa nos carcinomas espinocelulares que apresentavam alta queratinização, baixo pleomorfismo nuclear e baixo número de mitoses, características estas presentes nos tumores bem a moderadamente diferenciados que apresentam um baixo índice total de malignidade, de acordo com o sistema de graduação histopatológica proposto por BRYNE et al. ${ }^{21}$. 
TABELA 9 - Distribuição imuno-histoquímica dos anticorpos PCNA, E-caderina e $\beta$ catenina nos carcinomas escamosos basalóides, nos carcinomas espinocelulares pouco diferenciados e bem a moderadamente diferenciados de boca. Hospital do Câncer, São Paulo, 1970 a 2000

\begin{tabular}{|c|c|c|c|c|c|c|c|}
\hline \multirow{3}{*}{ Variável } & \multicolumn{6}{|c|}{ GRUPO } & \multirow{3}{*}{$p^{*}$} \\
\hline & \multicolumn{2}{|c|}{ CEB } & \multicolumn{2}{|c|}{ CEC/PD } & \multicolumn{2}{|c|}{ CEC/BD } & \\
\hline & $\mathrm{N}$ & $\%$ & $\mathrm{~N}$ & $\%$ & $\mathrm{~N}$ & $\%$ & \\
\hline \multicolumn{8}{|l|}{ PCNA $^{\#}$} \\
\hline$\leq 61 \%$ positividade & 5 & 33,3 & 15 & 57,7 & 16 & 57,1 & \multirow{2}{*}{0,256} \\
\hline$>61 \%$ positividade & 10 & 66,7 & 11 & 42,3 & 12 & 42,9 & \\
\hline \multicolumn{8}{|l|}{ E-caderina ${ }^{\#}$} \\
\hline Fraca & 15 & 88,2 & 21 & 80,8 & 15 & 53,6 & \multirow{2}{*}{$\mathbf{0 , 0 1 9}$} \\
\hline Forte & 2 & 11,8 & 5 & 19,2 & 13 & 46,4 & \\
\hline \multicolumn{8}{|l|}{$\beta$-catenina ${ }^{\#}$} \\
\hline Fraca & 10 & 58,8 & 19 & 79,2 & 19 & 73,1 & \multirow{2}{*}{0,355} \\
\hline Forte & 7 & 41,2 & 5 & 20,8 & 7 & 26,9 & \\
\hline TOTAL & 17 & 100,0 & 26 & 100,0 & 28 & 100,0 & \\
\hline
\end{tabular}

CEB: Carcinoma Escamoso Basalóide, CEC/PD: Carcinoma Espinocelular Pouco Diferenciado, CEC/BD: Carcinoma Espinocelular Bem a Moderadamente Diferenciado $p^{*}$ : valor obtido pelo teste do qui-quadrado considerando-se nível de significância de $5 \%$ \#: excluídos os casos inadequados para análise microscópica 
TABELA 10 - Distribuição do PCNA em relação às características clínicas dos três grupos de carcinomas de boca. Hospital do Câncer, São Paulo, 1970 a 2000

\begin{tabular}{|c|c|c|c|c|c|}
\hline \multirow{3}{*}{ Variável } & \multicolumn{4}{|c|}{ PCNA } & \multirow{3}{*}{$p^{*}$} \\
\hline & \multicolumn{2}{|c|}{$\leq 61$} & \multicolumn{2}{|c|}{$>61$} & \\
\hline & $\mathbf{N}$ & $\%$ & $\mathbf{N}$ & $\%$ & \\
\hline \multicolumn{6}{|l|}{ Estadiamento $\mathrm{T}$} \\
\hline $\mathrm{T} 1-2$ & 9 & 25,0 & 10 & 30,3 & \multirow[t]{2}{*}{0,622} \\
\hline T3-4 & 27 & 75,0 & 23 & 69,7 & \\
\hline \multicolumn{6}{|l|}{ Estadiamento $\mathbf{N}$} \\
\hline N0 & 10 & 27,8 & 10 & 30,3 & \multirow{2}{*}{0,817} \\
\hline $\mathrm{N}+$ & 26 & 72,2 & 23 & 69,7 & \\
\hline \multicolumn{6}{|l|}{ Localização } \\
\hline Língua & 7 & 19,4 & 8 & 24,2 & \multirow{3}{*}{0,657} \\
\hline Soalho & 12 & 33,3 & 13 & 39,4 & \\
\hline Retromolar/gengiva & 17 & 47,3 & 12 & 36,4 & \\
\hline \multicolumn{6}{|l|}{ Tipo de lesão } \\
\hline Ulcerovegetante & 9 & 25,0 & 8 & 24,2 & \multirow{2}{*}{0,942} \\
\hline Ulceroinfiltrativa & 27 & 75,0 & 25 & 75,8 & \\
\hline \multicolumn{6}{|l|}{ Recidiva local } \\
\hline Não & 26 & 72,2 & 25 & 75,8 & \multirow{2}{*}{0,738} \\
\hline Sim & 10 & 27,8 & 8 & 24,2 & \\
\hline \multicolumn{6}{|l|}{ Recidiva regional } \\
\hline Não & 26 & 72,2 & 25 & 75,8 & \multirow{2}{*}{0,738} \\
\hline Sim & 10 & 27,8 & 8 & 24,2 & \\
\hline \multicolumn{6}{|l|}{ Metástase a distância } \\
\hline Não & 32 & 88,9 & 29 & 87,9 & \multirow{2}{*}{0,999} \\
\hline Sim & 4 & 11,1 & 4 & 12,1 & \\
\hline TOTAL & 36 & 100,0 & 33 & 100,0 & \\
\hline
\end{tabular}

PCNA: Antígeno nuclear de proliferação celular $p^{*}$ : valor obtido pelo teste do qui-quadrado considerando-se nível de significância de $5 \%$ 
TABELA 11 - Distribuição do PCNA em relação às características microscópicas dos três grupos de carcinomas de boca. Hospital do Câncer, São Paulo, 1970 a 2000

\begin{tabular}{|c|c|c|c|c|c|}
\hline \multirow{3}{*}{ Variável } & \multicolumn{4}{|c|}{ PCNA } & \multirow{3}{*}{$p^{*}$} \\
\hline & \multicolumn{2}{|c|}{$\leq 61$} & \multicolumn{2}{|c|}{$>61$} & \\
\hline & $\mathbf{N}$ & $\%$ & $\mathbf{N}$ & $\%$ & \\
\hline \multicolumn{6}{|l|}{ Queratinização $^{\#}$} \\
\hline Alta & 18 & 58,1 & 12 & 52,2 & \multirow{2}{*}{0,667} \\
\hline Baixa & 13 & 41,9 & 11 & 47,8 & \\
\hline \multicolumn{6}{|c|}{ Pleomorfismo nuclear ${ }^{\#}$} \\
\hline Baixo & 24 & 77,4 & 18 & 78,3 & \multirow{2}{*}{0,941} \\
\hline Alto & 7 & 22,6 & 5 & 21,7 & \\
\hline \multicolumn{6}{|c|}{ Número de mitoses ${ }^{\#}$} \\
\hline Baixo & 26 & 83,9 & 15 & 65,2 & \multirow{2}{*}{0,197} \\
\hline Alto & 5 & 16,1 & 8 & 34,8 & \\
\hline \multicolumn{6}{|c|}{ Padrão de invasão } \\
\hline Compressivo & 2 & 6,5 & 7 & 30,4 & \multirow{2}{*}{$\mathbf{0 , 0 2 8}$} \\
\hline Infiltrativo & 29 & 93,5 & 16 & 69,6 & \\
\hline \multicolumn{6}{|c|}{ Infiltrado inflamatório ${ }^{\#}$} \\
\hline Intenso & 25 & 80,6 & 17 & 73,9 & \multirow[t]{2}{*}{0,556} \\
\hline Discreto & 6 & 19,4 & 6 & 26,1 & \\
\hline \multicolumn{6}{|c|}{ Índice de malignidade ${ }^{\#}$} \\
\hline Pouco agressivo & 12 & 38,7 & 9 & 39,1 & \multirow{2}{*}{0,975} \\
\hline Muito agressivo & 19 & 61,3 & 14 & 60,9 & \\
\hline \multicolumn{6}{|c|}{ Embolização vascular } \\
\hline Ausente & 23 & 63,9 & 22 & 66,7 & \multirow{2}{*}{0,809} \\
\hline Presente & 13 & 36,1 & 11 & 33,3 & \\
\hline \multicolumn{6}{|c|}{ Infiltração perineural } \\
\hline Ausente & 16 & 44,4 & 17 & 51,5 & \multirow{2}{*}{0,557} \\
\hline Presente & 20 & 55,6 & 16 & 48,5 & \\
\hline \multicolumn{6}{|c|}{ Infiltração muscular } \\
\hline Ausente & 7 & 19,4 & 11 & 33,3 & \multirow[t]{2}{*}{0,189} \\
\hline Presente & 29 & 80,6 & 22 & 66,7 & \\
\hline \multicolumn{6}{|l|}{ Infiltração óssea** } \\
\hline Ausente & 11 & 47,8 & 13 & 68,4 & \multirow{2}{*}{0,179} \\
\hline Presente & 12 & 52,2 & 6 & 31,6 & \\
\hline TOTAL & 36 & 100,0 & 33 & 100,0 & \\
\hline
\end{tabular}

PCNA: Antígeno nuclear de proliferação celular $p^{*}$ : valor obtido pelo teste do qui-quadrado considerando-se nível de significância de $5 \%$ \#: não incluídos os carcinomas escamosos basalóides **: excluídos os pacientes com informações ignoradas 
TABELA 12 - Distribuição de E-caderina e $\beta$-catenina em relação às características clínicas dos três grupos de carcinomas de boca. Hospital do Câncer, São Paulo, 1970 a 2000

\begin{tabular}{|c|c|c|c|c|c|c|c|c|c|c|}
\hline \multirow{3}{*}{ Variável } & \multicolumn{4}{|c|}{ E-caderina } & \multirow{3}{*}{$p^{*}$} & \multicolumn{4}{|c|}{$\beta$-catenina } & \multirow{3}{*}{$p^{*}$} \\
\hline & \multicolumn{2}{|c|}{ Fraca } & \multicolumn{2}{|c|}{ Forte } & & \multicolumn{2}{|c|}{ Fraca } & \multicolumn{2}{|c|}{ Forte } & \\
\hline & $\mathbf{N}$ & $\%$ & $\mathbf{N}$ & $\%$ & & $\mathbf{N}$ & $\%$ & $\mathbf{N}$ & $\%$ & \\
\hline \multicolumn{11}{|l|}{ Estadiamento $\mathrm{T}$} \\
\hline $\mathrm{T} 1-2$ & 14 & 27,5 & 6 & 30,0 & \multirow[t]{2}{*}{0,830} & 11 & 22,9 & 7 & 36,8 & \multirow[t]{2}{*}{0,246} \\
\hline T3-4 & 37 & 72,5 & 14 & 70,0 & & 37 & 77,1 & 12 & 63,2 & \\
\hline \multicolumn{11}{|l|}{ Estadiamento $\mathbf{N}$} \\
\hline N0 & 15 & 29,4 & 7 & 35,0 & \multirow{2}{*}{0,647} & 14 & 29,2 & 8 & 42,1 & \multirow{2}{*}{0,309} \\
\hline $\mathrm{N}+$ & 36 & 70,6 & 13 & 65,0 & & 34 & 70,8 & 11 & 57,9 & \\
\hline \multicolumn{11}{|l|}{ Localização } \\
\hline Língua & 11 & 21,6 & 4 & 20,0 & \multirow{3}{*}{ NA } & 12 & 25,0 & 1 & 5,3 & \multirow{3}{*}{ NA } \\
\hline Soalho & 21 & 41,2 & 6 & 30,0 & & 16 & 33,3 & 10 & 52,6 & \\
\hline Retromolar/gengiva & 19 & 37,2 & 10 & 50,0 & & 20 & 41,7 & 8 & 42,1 & \\
\hline \multicolumn{11}{|l|}{ Tipo de lesão } \\
\hline Ulcerovegetante & 12 & 23,5 & 6 & 30,0 & \multirow{2}{*}{0,573} & 12 & 25,0 & 6 & 31,6 & \multirow{2}{*}{0,584} \\
\hline Ulceroinfiltrativa & 39 & 76,5 & 14 & 70,0 & & 36 & 75,0 & 13 & 68,4 & \\
\hline \multicolumn{11}{|l|}{ Recidiva local } \\
\hline Não & 36 & 70,6 & 16 & 80,0 & \multirow{2}{*}{0,420} & 35 & 72,9 & 15 & 78,9 & \multirow{2}{*}{0,760} \\
\hline Sim & 15 & 29,4 & 4 & 20,0 & & 13 & 27,1 & 4 & 21,1 & \\
\hline \multicolumn{11}{|l|}{ Recidiva regional } \\
\hline Não & 39 & 76,5 & 14 & 70,0 & \multirow{2}{*}{0,573} & 37 & 77,1 & 14 & 73,7 & \multirow{2}{*}{0,760} \\
\hline Sim & 12 & 23,5 & 6 & 30,0 & & 11 & 22,9 & 5 & 26,3 & \\
\hline \multicolumn{11}{|l|}{ Metástase a distância } \\
\hline Não & 43 & 84,3 & 20 & 100,0 & \multirow{2}{*}{0,095} & 41 & 85,4 & 18 & 94,7 & \multirow{2}{*}{0,424} \\
\hline Sim & 8 & 15,7 & 0 & 0,0 & & 7 & 14,6 & 1 & 5,3 & \\
\hline TOTAL & 51 & 100,0 & 20 & 100,0 & & 48 & 100,0 & 19 & 100,0 & \\
\hline
\end{tabular}

$p^{*}$ : valor obtido pelo teste do qui-quadrado considerando-se nível de significância de $5 \%$ NA: não se aplica 
TABELA 13 - Distribuição de E-caderina e $\beta$-catenina em relação às características microscópicas dos três grupos de carcinomas de boca. Hospital do Câncer, São Paulo, 1970 a 2000

\begin{tabular}{|c|c|c|c|c|c|c|c|c|c|c|}
\hline \multirow{3}{*}{ Variável } & \multicolumn{4}{|c|}{ E-caderina } & \multirow{3}{*}{$p^{*}$} & \multicolumn{4}{|c|}{$\beta$-catenina } & \multirow{3}{*}{$p^{*}$} \\
\hline & \multicolumn{2}{|c|}{ Fraca } & \multicolumn{2}{|c|}{ Forte } & & \multicolumn{2}{|c|}{ Fraca } & \multicolumn{2}{|c|}{ Forte } & \\
\hline & $\mathbf{N}$ & $\%$ & $\mathbf{N}$ & $\%$ & & $\mathbf{N}$ & $\%$ & $\mathbf{N}$ & $\%$ & \\
\hline \multicolumn{11}{|l|}{ Queratinização $^{\#}$} \\
\hline Alta & 15 & 41,7 & 15 & 83,3 & \multirow{2}{*}{0,004} & 21 & 55,3 & 8 & 66,7 & \multirow{2}{*}{0,485} \\
\hline Baixa & 21 & 58,3 & 3 & 16,7 & & 17 & 44,7 & 4 & 33,3 & \\
\hline \multicolumn{11}{|c|}{ Pleomorfismo nuclear } \\
\hline Baixo & 25 & 69,4 & 17 & 94,4 & \multirow{2}{*}{0,044} & 27 & 71,0 & 11 & 91,7 & \multirow[t]{2}{*}{0,248} \\
\hline Alto & 11 & 30,6 & 1 & 5,6 & & 11 & 29,0 & 1 & 8,3 & \\
\hline \multicolumn{11}{|c|}{ Número de mitoses ${ }^{\#}$} \\
\hline Baixo & 24 & 66,7 & 17 & 94,4 & \multirow[t]{2}{*}{0,040} & 28 & 73,7 & 10 & 83,3 & \multirow{2}{*}{0,705} \\
\hline Alto & 12 & 33,3 & 1 & 5,6 & & 10 & 26,3 & 2 & 16,7 & \\
\hline \multicolumn{11}{|c|}{ Padrão de invasão } \\
\hline Compressivo & 8 & 22,2 & 1 & 5,6 & \multirow{2}{*}{0,244} & 7 & 18,4 & 2 & 16,7 & \multirow{2}{*}{0,999} \\
\hline Infiltrativo & 28 & 77,8 & 17 & 94,4 & & 31 & 81,6 & 10 & 83,3 & \\
\hline \multicolumn{11}{|c|}{ Infiltrado inflamatório ${ }^{\#}$} \\
\hline Intenso & 28 & 77,8 & 14 & 77,8 & \multirow[t]{2}{*}{0,999} & 30 & 78,9 & 9 & 75,0 & \multirow{2}{*}{0,999} \\
\hline Discreto & 8 & 22,2 & 4 & 22,2 & & 8 & 21,1 & 3 & 25,0 & \\
\hline \multicolumn{11}{|c|}{ Índice de malignidade ${ }^{\#}$} \\
\hline Pouco agressivo & 9 & 25,0 & 12 & 66,7 & \multirow{2}{*}{$\mathbf{0 , 0 0 3}$} & 14 & 36,8 & 6 & 50,0 & \multirow[t]{2}{*}{0,506} \\
\hline Muito agressivo & 27 & 75,0 & 6 & 33,3 & & 24 & 63,2 & 6 & 50,0 & \\
\hline Embolização vas & & & & & & & & & & \\
\hline Ausente & 34 & 66,7 & 13 & 65,0 & 0.894 & 33 & 68,7 & 12 & 63,2 & 0.660 \\
\hline Presente & 17 & 33,3 & 7 & 35,0 & & 15 & 31,3 & 7 & 36,8 & \\
\hline Infiltração perine & & & & & & & & & & \\
\hline Ausente & 26 & 51,0 & 9 & 45,0 & 0,650 & 22 & 45,8 & 13 & 68,4 & 0,095 \\
\hline Presente & 25 & 49,0 & 11 & 55,0 & & 26 & 54,2 & 6 & 31,6 & \\
\hline Infiltração muscı & & & & & & & & & & \\
\hline Ausente & 14 & 27,5 & 5 & 25,0 & 0,834 & 10 & 20,8 & 9 & 47,4 & $\mathbf{0 , 0 3 0}$ \\
\hline Presente & 37 & 72,5 & 15 & 75,0 & & 38 & 79,2 & 10 & 52,6 & \\
\hline Infiltração óssea & & & & & & & & & & \\
\hline Ausente & 15 & 51,7 & 10 & 71,4 & 0,220 & 17 & 54,8 & 7 & 63,6 & 0,731 \\
\hline Presente & 14 & 48,3 & 4 & 28,6 & & 14 & 45,2 & 4 & 36,4 & \\
\hline TOTAL & 51 & 100,0 & 20 & 100,0 & & 48 & 100,0 & 19 & 100,0 & \\
\hline
\end{tabular}

$p^{*}$ : valor obtido pelo teste do qui-quadrado considerando-se nível de significância de $5 \%$

\#: não incluídos os carcinomas escamosos basalóides

**: excluídos os pacientes com informações ignoradas 
Além do comprometimento linfonodal detectado clinicamente, nenhuma correlação estatisticamente significativa entre o comprometimento linfonodal confirmado microscopicamente $(\mathrm{pN})$ e a expressão do PCNA, E-caderina e $\beta$-catenina foi estabelecida nos três grupos de carcinomas de boca estudados, como pode ser observado na Tabela 14.

TABELA 14 - Distribuição de PCNA, E-caderina e $\beta$-catenina em relação ao comprometimento linfonodal confirmado microscopicamente dos três grupos de carcinomas de boca. Hospital do Câncer, São Paulo, 1970 a 2000

\begin{tabular}{|c|c|c|c|c|c|}
\hline \multirow{3}{*}{ Variável } & \multicolumn{4}{|c|}{ Comprometimento linfonodal } & \multirow{3}{*}{$p^{*}$} \\
\hline & \multicolumn{2}{|c|}{ pN- } & \multicolumn{2}{|c|}{$\mathbf{p N}+$} & \\
\hline & $\mathrm{N}$ & $\%$ & $\mathrm{~N}$ & $\%$ & \\
\hline \multicolumn{6}{|l|}{$\mathbf{P C N A}^{\#}$} \\
\hline$\leq 61 \%$ positividade & 15 & 51,7 & 21 & 53,8 & \multirow{2}{*}{0,862} \\
\hline$>61 \%$ positividade & 14 & 48,3 & 18 & 46,2 & \\
\hline \multicolumn{6}{|l|}{ E-caderina } \\
\hline Fraca & 21 & 67,7 & 30 & 76,9 & \multirow{2}{*}{0,391} \\
\hline Forte & 10 & 32,3 & 9 & 23,1 & \\
\hline \multicolumn{6}{|l|}{$\beta$-catenina ${ }^{\#}$} \\
\hline Fraca & 19 & 65,5 & 28 & 75,7 & \multirow[b]{2}{*}{0,366} \\
\hline Forte & 10 & 34,5 & 9 & 24,3 & \\
\hline TOTAL & 31 & 100,0 & 39 & 100,0 & \\
\hline
\end{tabular}

pN-: ausência de comprometimento linfonodal confirmada microscopicamente; pN+: presença de comprometimento linfonodal confirmada microscopicamente; PCNA: Antígeno nuclear de proliferação celular

$p^{*}$ : valor obtido pelo teste do qui-quadrado considerando-se nível de significância de $5 \%$

\#: excluídos os casos inadequados para análise microscópica 

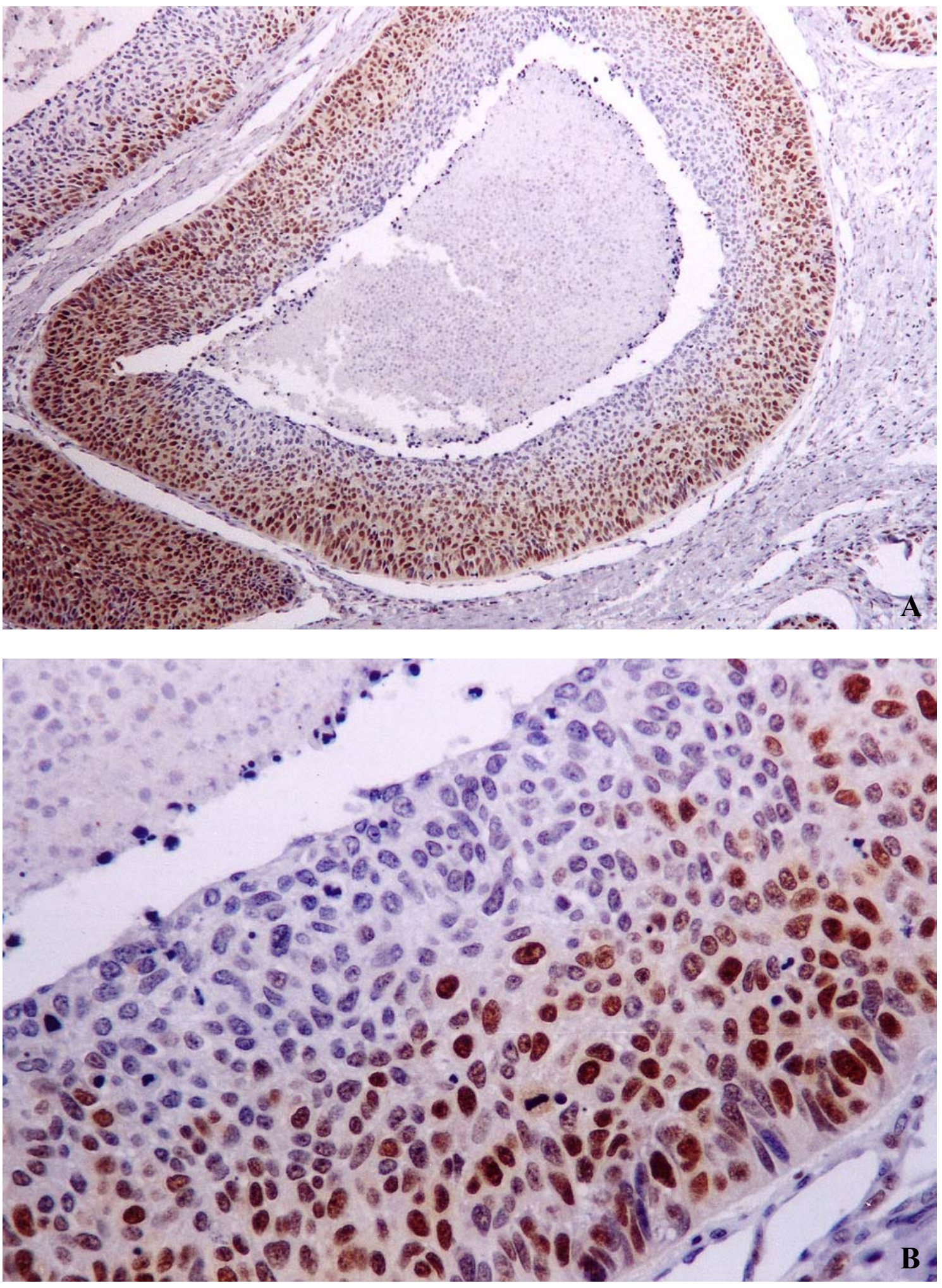

FIGURA 9 - Imunopositividade ao PCNA das células epiteliais periféricas das ilhotas tumorais no $\mathrm{CEB}$ (IHQ, aumento original $\mathrm{A}=100 \mathrm{X}$ e $\mathrm{B}=400 \mathrm{X}$ ) 

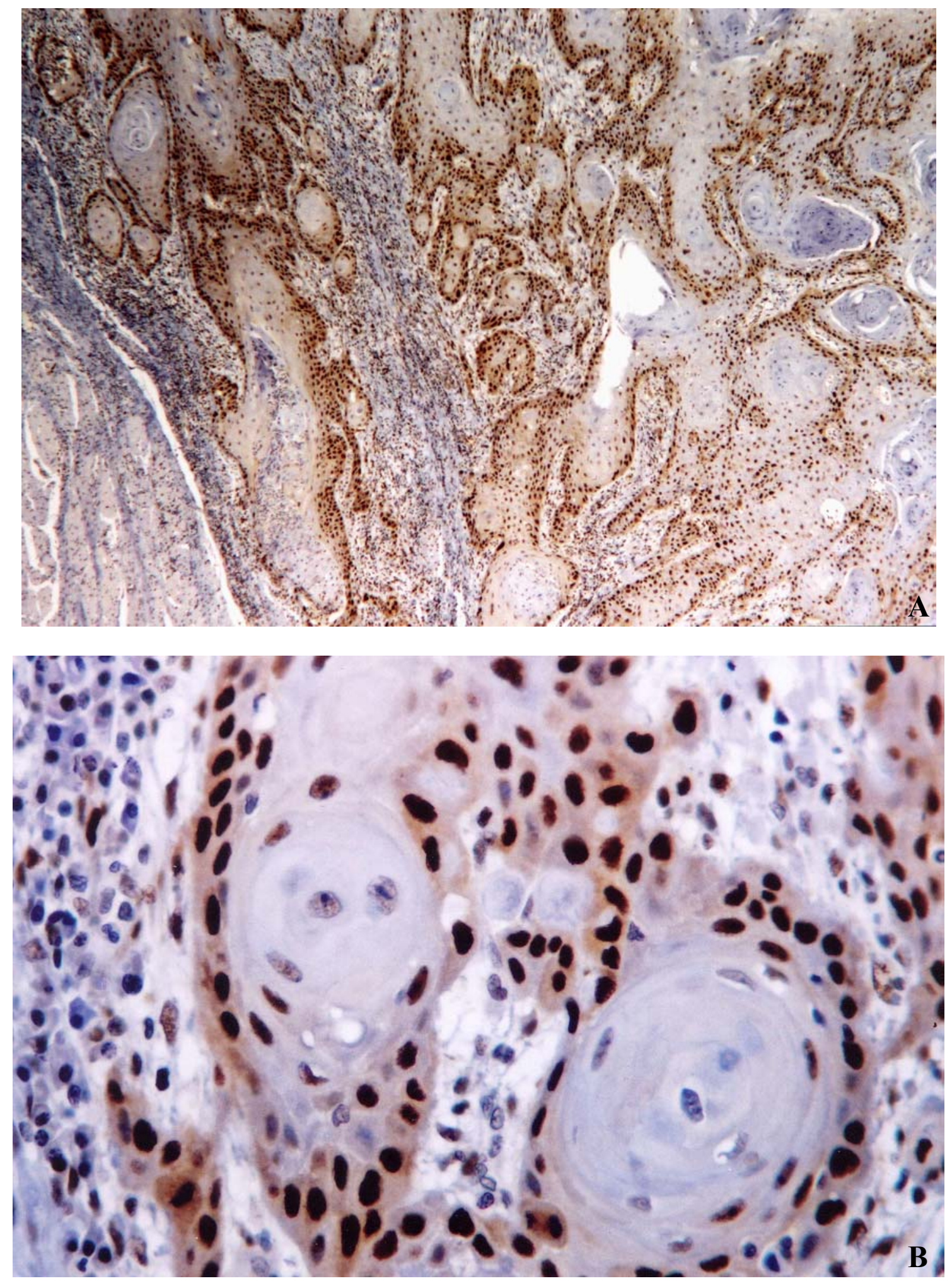

FIGURA 10 - Imunopositividade ao PCNA das células neoplásicas do CEC/BD (A e $\mathrm{B})$, exceto nas pérolas córneas $(\mathrm{B})$ e áreas focais de queratinização. (IHQ, aumento original $A=50 \mathrm{X}$ e $\mathrm{B}=400 \mathrm{X}$ ) 

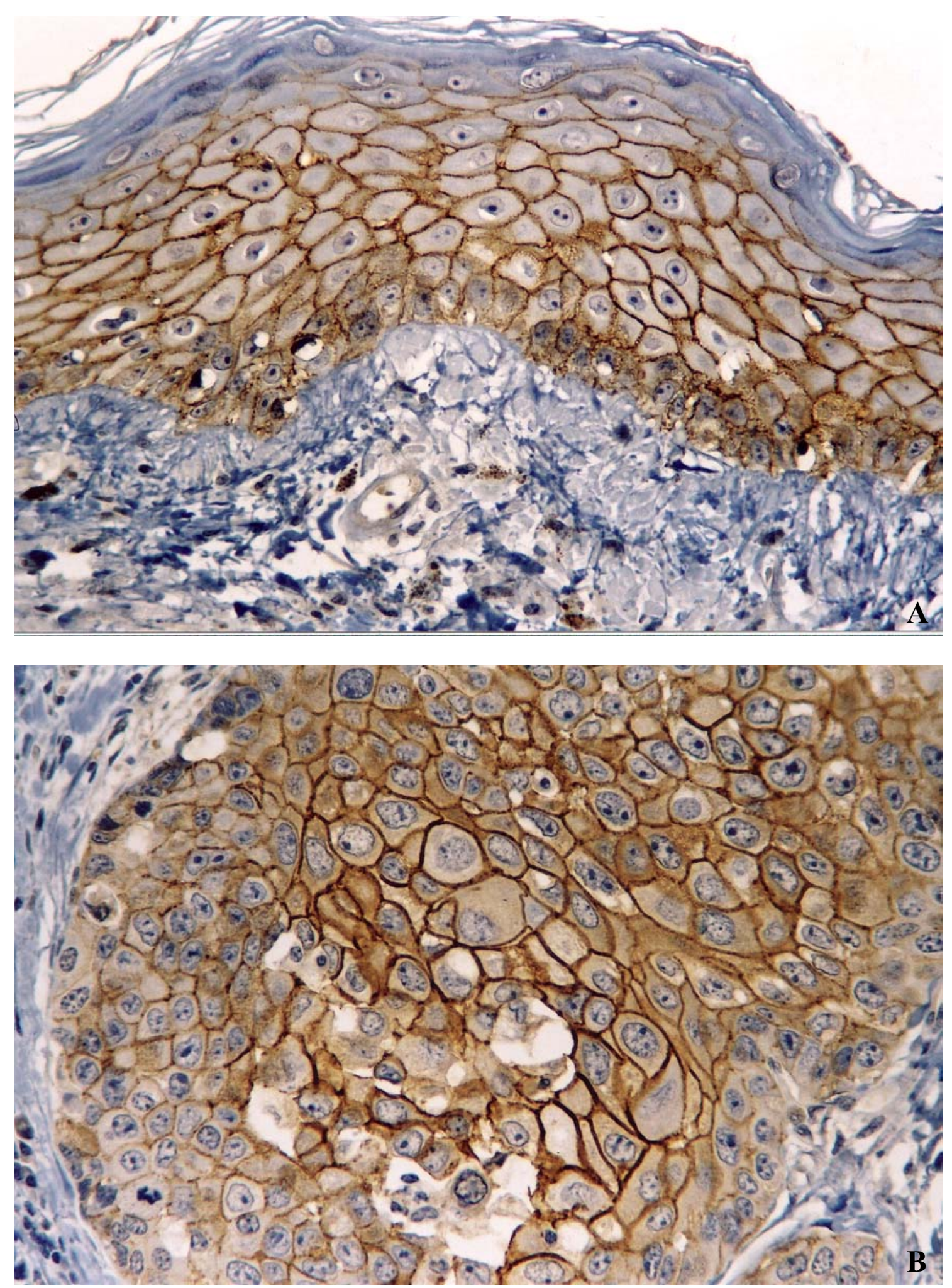

FIGURA 11 - Imunopositividade à E-caderina na mucosa bucal normal (A). Em B, forte expressão membranosa da E-caderina no CEC/BD. (IHQ, aumento original $\mathrm{A}$ e $\mathrm{B}=400 \mathrm{X}$ ) 

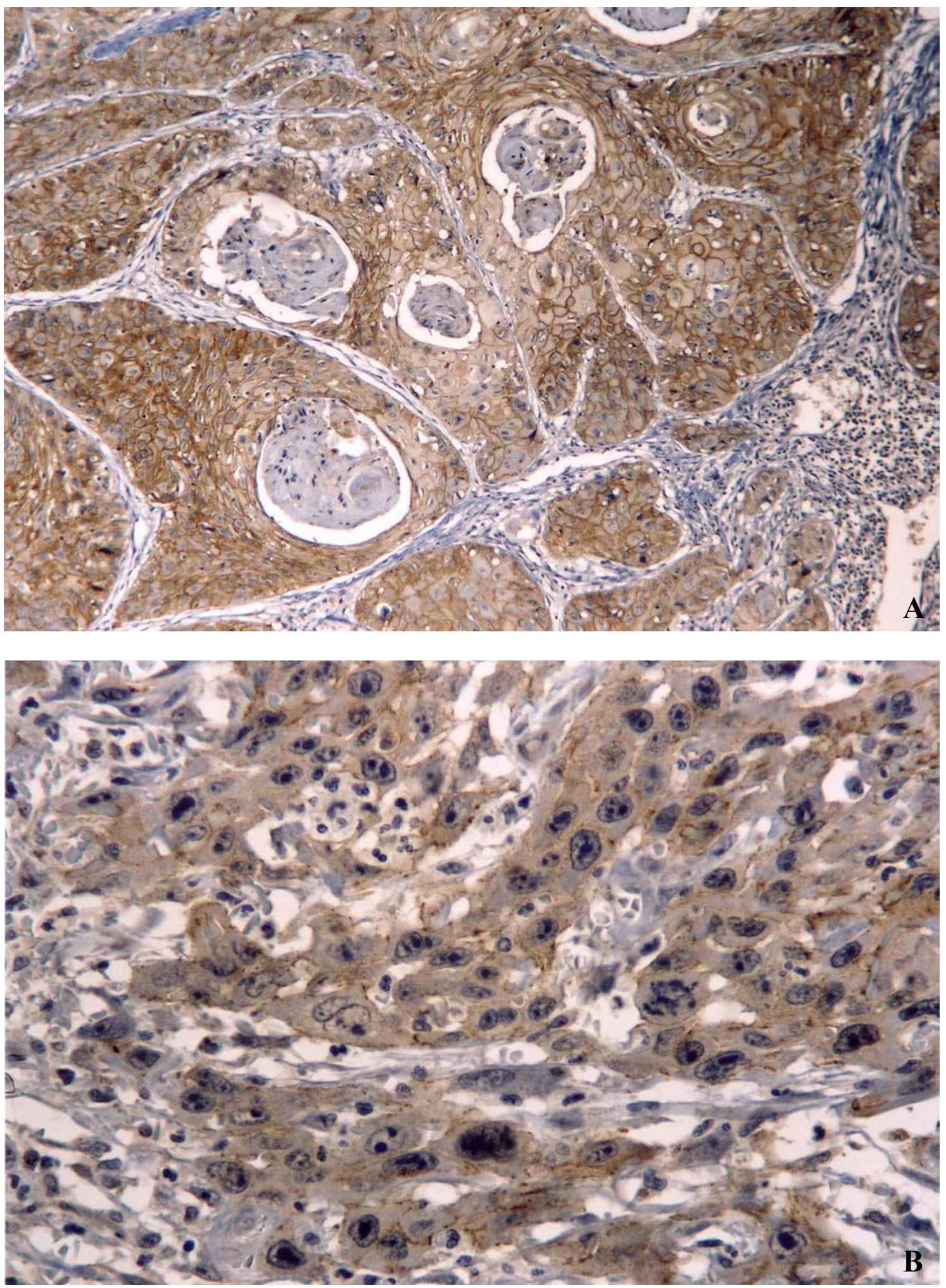

FIGURA 12 - Imunoexpressão da E-caderina no CEC/BD (A), exceto nas áreas de queratinização, e redução desta expressão no CEC/PD (B).(IHQ, aumento original $\mathrm{A}=50 \mathrm{X}$ e $\mathrm{B}=100 \mathrm{X}$ ) 

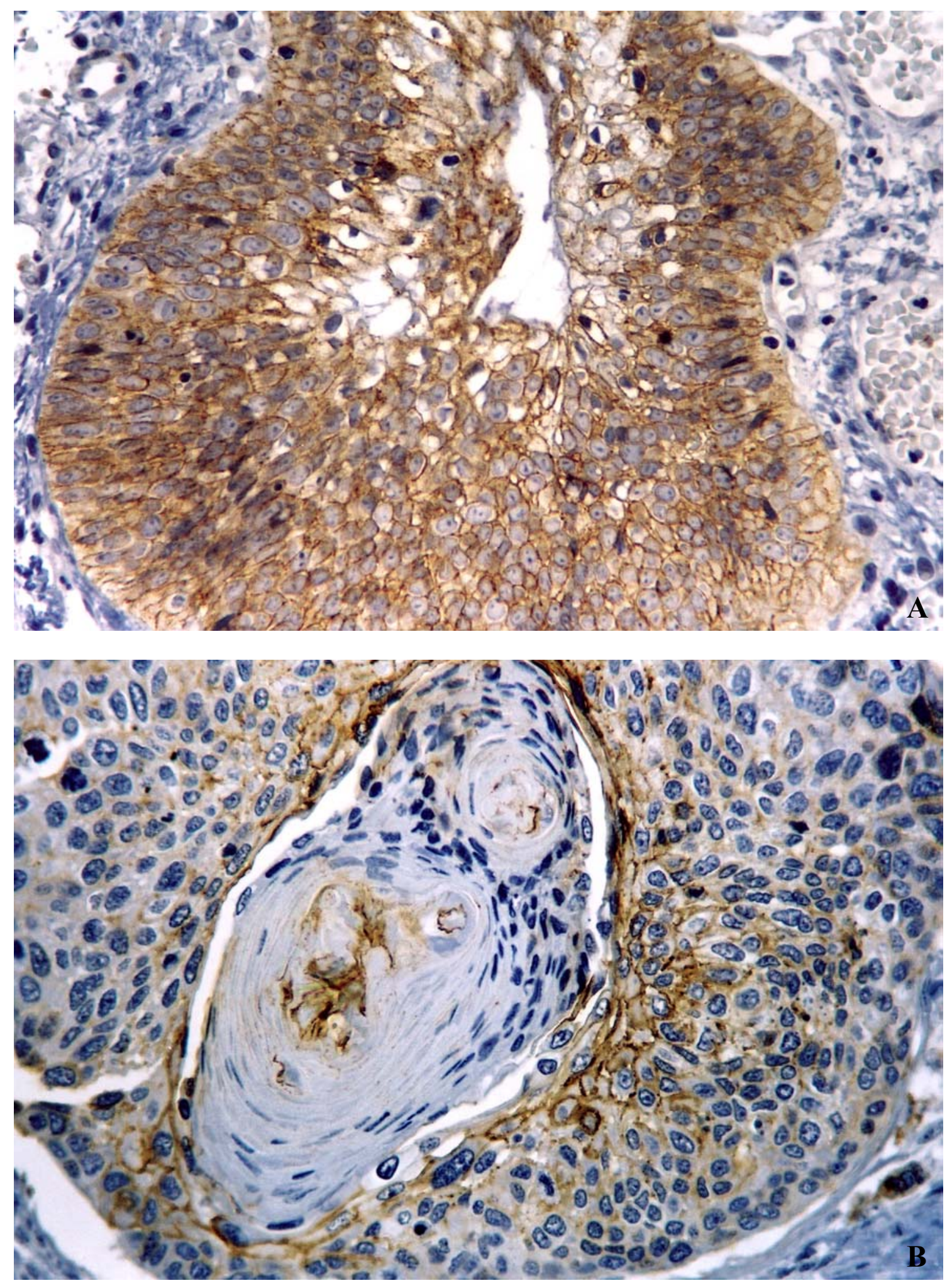

FIGURA 13- Imunoexpressão da E-caderina no CEB com padrão membranoso em A e redução significativa da expressão em $\mathrm{B}$. (IHQ, aumento original $\mathrm{A}$ e $\mathrm{B}=$ 400X) 

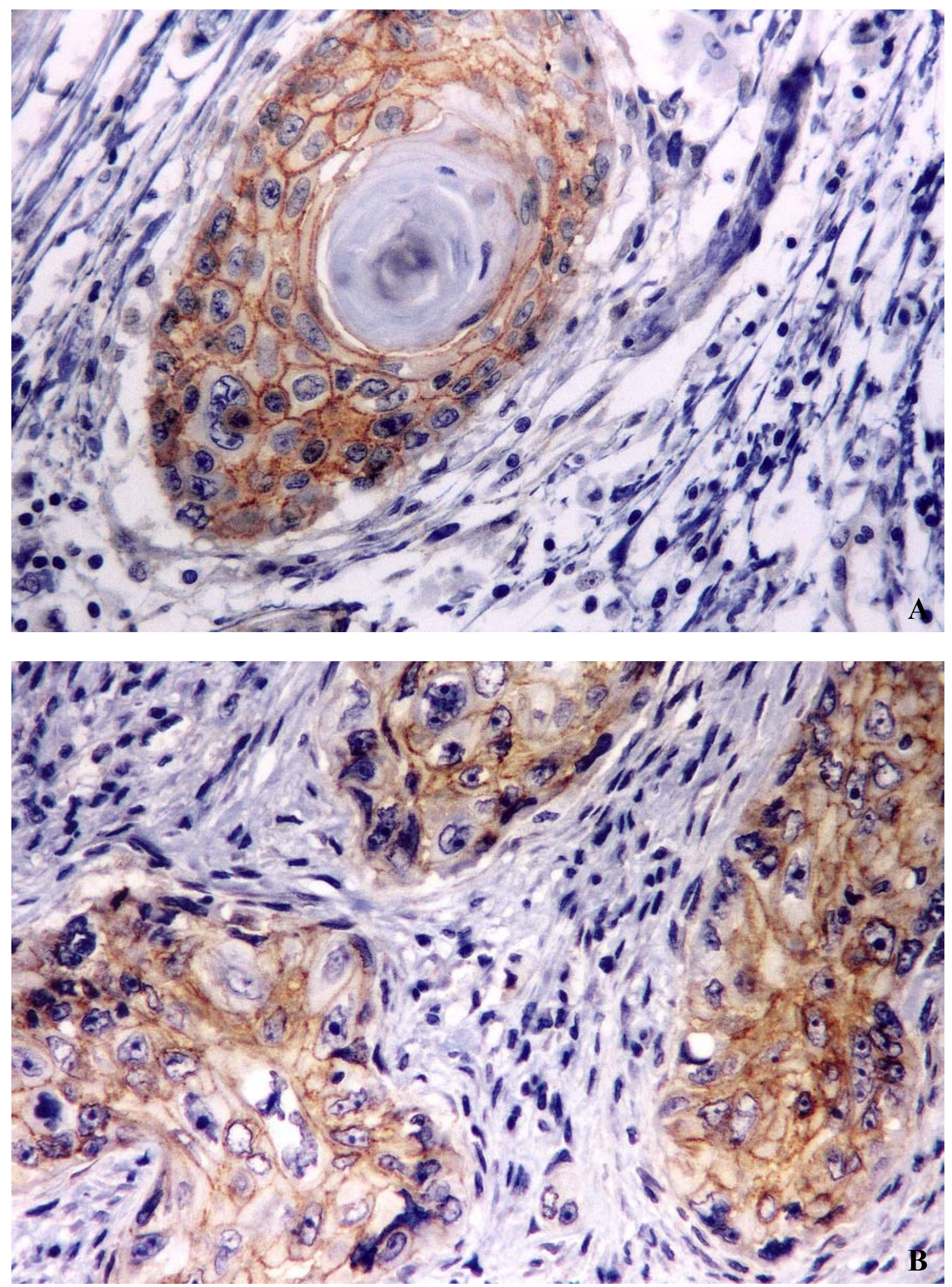

FIGURA 14- Imunoexpressão com padrão membranoso da $\beta$-catenina no CEC/BD (A) e com padrão citoplasmático irregular no CEC/PD (B). (IHQ, aumento original $\mathrm{A}$ e $\mathrm{B}=400 \mathrm{X}$ ) 

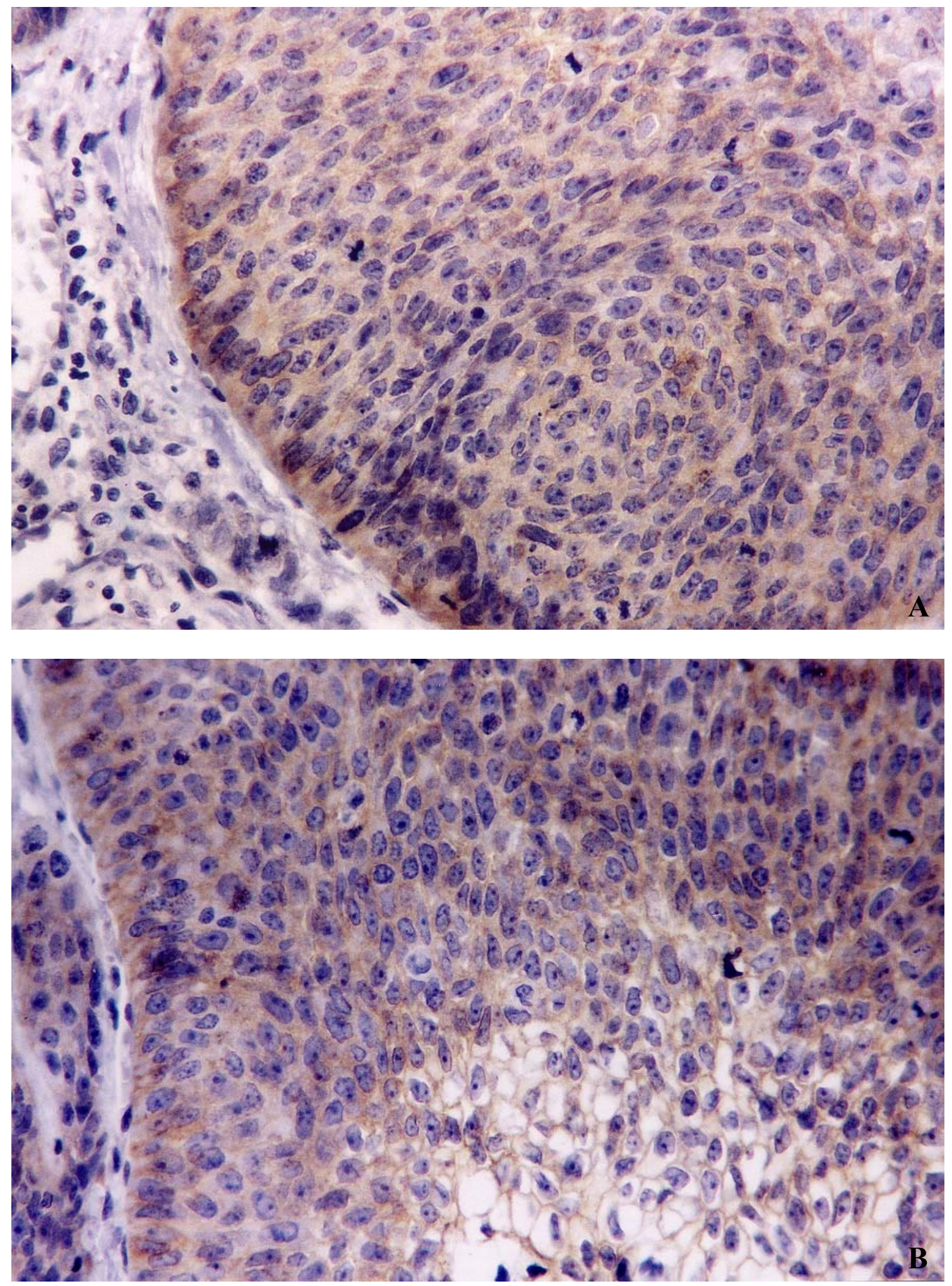

FIGURA 15- Imunoexpressão da $\beta$-catenina nas células epiteliais neoplásicas do CEB. (IHQ, aumento original A e B= 400X) 


\subsection{Análise de Sobrevida}

O período de seguimento dos pacientes do grupo CEB variou de 3,2-168 meses (média 60 meses, desvio padrão 52,0), para o grupo CEC/PD variou de 1,5-187 meses (média 38 meses, desvio padrão 43,5 meses) e para o grupo CEC/BD de 0,36-322 meses (média 77 meses, desvio padrão 91,8 meses). Ao final do estudo, em janeiro de 2004, quatro pacientes $(23,5 \%)$ do grupo CEB estavam vivos, sem evidências de recidiva da doença, 11 pacientes $(64,7 \%)$ faleceram em decorrência do tumor primário, um paciente $(5,9 \%)$ morreu por outras causas não relacionadas ao câncer e um paciente $(5,9 \%)$ foi considerado perdido de vista.

No grupo CEC/PD, dois pacientes $(7,7 \%)$ morreram logo após a cirurgia para excisão do tumor primário, 18 pacientes $(69,2 \%)$ faleceram em decorrência do tumor primário, quatro pacientes $(15,4 \%)$ morreram por outras causas não relacionadas ao câncer e dois pacientes foram considerados perdidos de vista. Dos pacientes pertencentes ao grupo $\mathrm{CEC} / \mathrm{BD}$, sete (25,0\%) apresentavam-se vivos sem evidências de recidiva da doença, dois $(7,1 \%)$ morreram logo após a cirurgia inicial, 14 faleceram em decorrência do tumor primário, três $(10,8 \%)$ faleceram por outras causas não relacionadas ao câncer e apenas dois $(7,1 \%)$ foram considerados perdidos de vista.

As probabilidades de sobrevida global e sobrevida livre de doença, acumuladas em 5 e 10 anos, foram calculadas pelo estimador produto-limite de Kaplan-Meier. A comparação entre as curvas de sobrevida global e sobrevida livre de doença, realizadas através do teste de log-rank não apresentaram diferenças estatisticamente significativas entre os grupos CEB, CEC/PD e CEC/BD (Tabelas 15 e 16 e Figuras 16 e 17).

Também não se detectou diferença estatística entre as probabilidades de sobrevida global e sobrevida livre de doença, quanto às marcações pelos anticorpos PCNA, E-caderina e $\beta$-catenina, para os pacientes com CEB, CEC/PD e CEC/BD (Tabelas 15 e 16). 
TABELA 15 - Análise de sobrevida global dos pacientes com carcinomas de boca. Probabilidade de sobrevida acumulada pela técnica de Kaplan-Meier

\begin{tabular}{lccc}
\hline \multicolumn{1}{c}{ Variável } & \multicolumn{2}{c}{ Sobrevida Global } & \\
& $\mathbf{5}$ anos (\%) & $\mathbf{1 0}$ anos (\%) & $\boldsymbol{p}^{*}$ \\
Grupo & & & \\
CEB & 46,7 & 23,8 & 0,093 \\
CEC/PD & 18,5 & 13,8 & \\
CEC/BD & 42,9 & 42,9 & \\
PCNA & & & 0,551 \\
$\leq 61 \%$ positividade & 27,8 & 27,8 & \\
$>61 \%$ positividade & 39,0 & 25,8 & 0,440 \\
E-caderina & & & \\
Fraco & 33,1 & 23,0 & \\
Forte & 40,0 & 40,0 & \\
$\beta$-catenina & & & \\
Fraco & 27,1 & 22,4 & \\
Forte & 57,4 & 43,2 & \\
\hline \hline
\end{tabular}

CEB: Carcinoma Escamoso Basalóide, CEC/PD: Carcinoma Espinocelular Pouco Diferenciado, CEC/BD: Carcinoma Espinocelular Bem a Moderadamente Diferenciado $p^{*}$ : nível descritivo do teste log-rank 


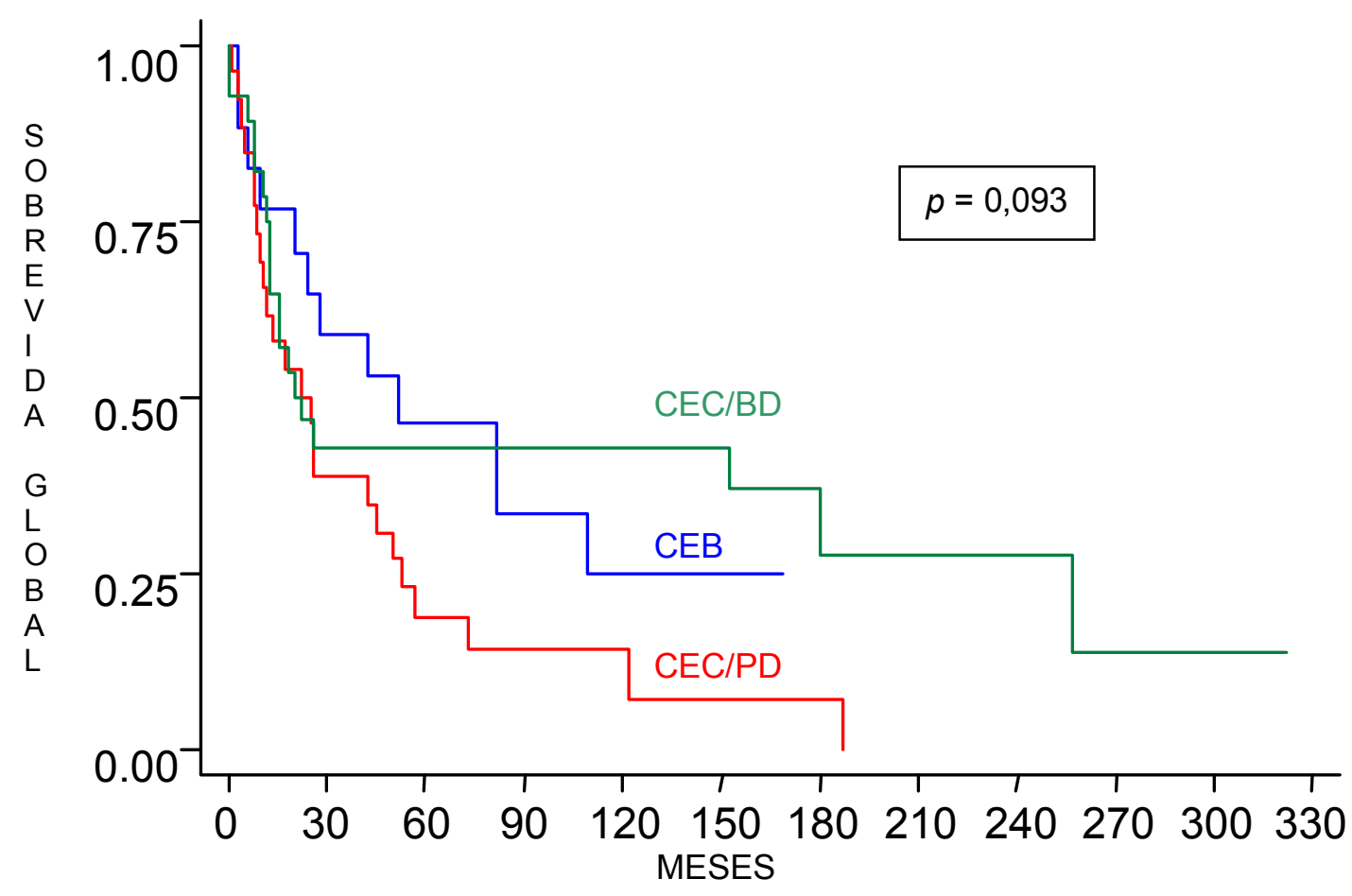

FIGURA 16 - Sobrevida global dos pacientes com carcinomas escamosos basalóides (CEB), carcinomas espinocelulares pouco diferenciados (CEC/PD) e carcinomas espinocelulares bem diferenciados (CEC/BD) de boca. Porcentagem de sobrevida acumulada pela técnica de Kaplan-Meier 
TABELA 16 - Análise de sobrevida livre de doença dos pacientes com carcinomas de boca. Probabilidade de sobrevida acumulada pela técnica de Kaplan-Meier

\begin{tabular}{lccc}
\hline \multicolumn{1}{c}{ Variável } & \multicolumn{2}{c}{ Sobrevida Livre de Doença } & \\
& $\mathbf{5}$ anos (\%) & $\mathbf{1 0} \mathbf{a n o s}(\mathbf{\%})$ & $\boldsymbol{p}^{*}$ \\
\hline Grupo & & & \\
CEB & 39,6 & 39,6 & 0,288 \\
CEC/PD & 38,5 & 25,6 & \\
CEC/BD & 60,0 & 60,0 & \\
PCNA & & & 0,367 \\
$\leq 61 \%$ positividade & 41,1 & 41,1 & \\
$>61 \%$ positividade & 53,1 & 48,3 & 0,202 \\
E-caderina & & & \\
Fraco & 43,5 & 40,0 & \\
Forte & 57,1 & 57,1 & \\
$\beta$-catenina & & & \\
Fraco & 42,9 & 42,9 & \\
Forte & 60,6 & 53,0 & \\
\hline \hline
\end{tabular}

CEB: Carcinoma Escamoso Basalóide, CEC/PD: Carcinoma Espinocelular Pouco Diferenciado, CEC/BD: Carcinoma Espinocelular Bem a Moderadamente Diferenciado $p^{*}$ : nível descritivo do teste log-rank 


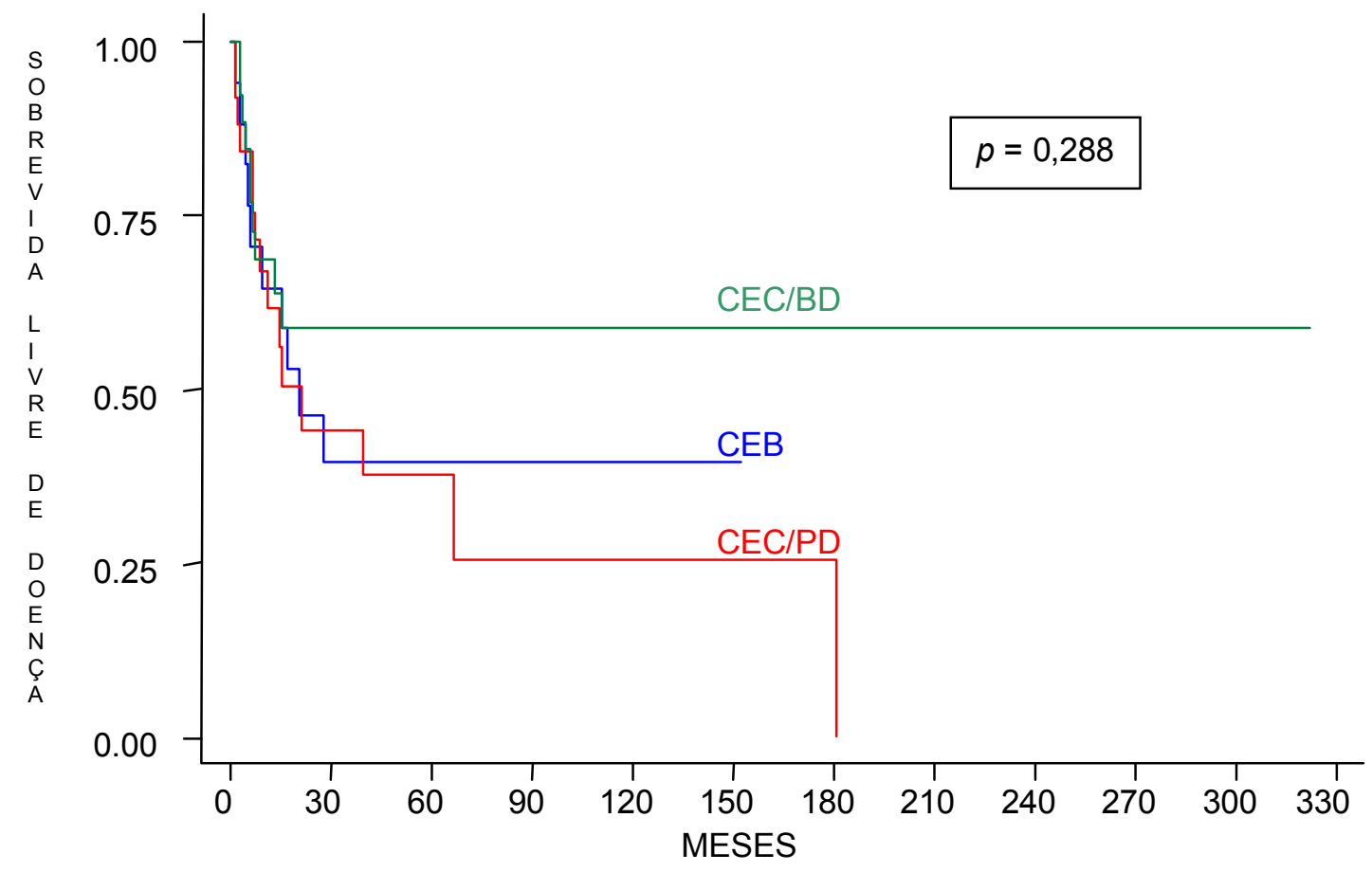

FIGURA 17 - Sobrevida livre de doença dos pacientes com carcinomas escamosos basalóides (CEB), carcinomas espinocelulares pouco diferenciados (CEC/PD) e carcinomas espinocelulares bem diferenciados (CEC/BD) de boca. Porcentagem de sobrevida acumulada pela técnica de Kaplan-Meier 
Devido à pequena casuística em cada grupo (CEB, CEC/PD e CEC/BD), realizou-se a análise multivariada para todos os carcinomas (71 casos). O modelo de regressão de Cox foi realizado para a sobrevida específica, através da técnica "stepwise", com nível de significância igual a $10 \%$.

Todas as variáveis de interesse foram incluídas na análise multivariada, com exclusão baseada no nível de significância de $10 \%$ e a partir deste processo verificamos que a única variável significativa foi a presença de metástase em linfonodos regionais $(\mathrm{N}+)$. Os pacientes com comprometimento linfonodal $(\mathrm{N}+)$ apresentaram um risco relativo de morte (RR) 2,16 vezes maior (intervalo de confiança $=1,1-4,2$ ) que os pacientes sem comprometimento linfonodal (N0) $(\mathrm{p}=0,025)$, independentemente da idade, gênero, grupo tumoral e positividade aos marcadores E-caderina, $\beta$-catenina e PCNA. 
6 DISCUSSÃO 


\section{DISCUSSÃO}

O carcinoma escamoso basalóide tem sido considerado uma variante agressiva do carcinoma espinocelular em diferentes sítios anatômicos, entretanto os estudos comparativos entre estas duas neoplasias na cavidade bucal baseiam-se em amostras com um número reduzido de pacientes impossibilitando um delineamento mais preciso de seu comportamento biológico bem como de sua evolução clínica.

Teriam os pacientes com CEB um pior prognóstico, quando comparados com os portadores de CEC? Com o objetivo de trazer contribuições sobre o comportamento clínico e biológico do $\mathrm{CEB}$, fornecendo subsídios para se estabelecer um prognóstico e uma opção terapêutica mais apropriados, desenvolvemos o presente estudo.

Parte da nossa amostra de carcinomas foi previamente estudada por GÓES ${ }^{32}$ em 2003 que verificou uma evolução clínica e comportamento biológico semelhantes para o CEB e o CEC pouco diferenciado localizados em língua, soalho, gengiva inferior e região retromolar, com localização e estadiamento clínico equivalentes. No presente estudo, além do CEB e CEC/PD, foram incluídos também os carcinomas espinocelulares bem a moderadamente diferenciados que comumente determinam um prognóstico mais favorável para os pacientes.

A análise comparativa do $\mathrm{CEB}, \mathrm{CEC} / \mathrm{PD}$ e $\mathrm{CEC} / \mathrm{BD}$ revelou resultados demográficos e clínicos semelhantes àqueles descritos na literatura. Estas neoplasias ocorreram principalmente em pacientes do gênero masculino, com idade média de 58 anos, tabagistas e etilistas. 
Quanto à localização, a maioria dos tumores do grupo CEB ocorreu em soalho bucal e, nos grupos $\mathrm{CEC} / \mathrm{PD}$ e $\mathrm{CEC} / \mathrm{BD}$, o local mais comumente acometido pelas neoplasias foi a região retromolar/gengiva. Clinicamente, os carcinomas apresentavam-se, predominantemente, como lesões ulceroinfiltrativas nos três grupos estudados (Tabela 4).

No momento do diagnóstico, a maioria dos pacientes com CEB, CEC/PD e CEC/BD apresentava estádios clínicos avançados e, em aproximadamente 70,0\% destes, os linfonodos regionais estavam clinicamente comprometidos (Tabela 4). Esses resultados confirmam os de ALTAVILLA et al. ${ }^{6}$, BANKS et al. ${ }^{13}$, COPPOLA et al. ${ }^{28}$, FERLITO et al. ${ }^{30}$, KLIJANIENKO et al. $^{40}$, LAM et al. ${ }^{44}$, LARNER et al. ${ }^{45}$, LUNA et al. ${ }^{49}$, PAULINO et al. ${ }^{54}$, RASLAN et al. ${ }^{57}$, SARBIA et al. ${ }^{60}$, WAIN et al. ${ }^{82}$ e WINZENBURG et al. ${ }^{90}$, que também verificaram uma alta freqüência de comprometimento linfonodal no momento do diagnóstico dos CEBs da região de cabeça e pescoço.

Todos os pacientes com $\mathrm{CEB}, \mathrm{CEC} / \mathrm{PD}$ e $\mathrm{CEC} / \mathrm{BD}$ incluídos neste estudo foram submetidos à cirurgia como tratamento inicial e ao esvaziamento cervical ipsilateral ou bilateral com exceção de um paciente do grupo $\mathrm{CEC/BD}$ que não foi submetido ao esvaziamento cervical. A complementação radioterápica foi realizada na maioria dos pacientes dos três grupos tumorais, enquanto que a quimioterapia complementar foi administrada em apenas $17,7 \%, 26,9 \%$ e em $17,9 \%$ dos pacientes dos grupos CEB, CEC/PD e $\mathrm{CEC} / \mathrm{BD}$, respectivamente.

O tratamento para os carcinomas espinocelulares da região de cabeça e pescoço incluindo a boca, como verificado em nossa casuística e também por outros autores $^{6,14,23,45,49,57,80}$, consiste na ressecção cirúrgica do tumor complementado pela radioterapia e pela quimioterapia. Em neoplasias como o $\mathrm{CEB}$, consideradas altamente agressivas e com tendência para o desenvolvimento de metástases a distância em mais da 
metade dos $\operatorname{casos}^{13,40,82}$, alguns autores ${ }^{6,14,23,45,49,57,80}$ recomendam a utilização da quimioterapia sistêmica como complementação do tratamento cirúrgico e radioterápico.

Com relação à evolução clínica tumoral, verificamos que a maior taxa de recidiva local ocorreu no grupo CEC/PD (38,5\%) quando comparado ao CEB e CEC/BD como pode ser visualizado na Tabela 5. A freqüência de recidiva local para o CEB foi de 17,7\%, valor este próximo àqueles encontrados por LUNA et al. ${ }^{49}$, BANKS et al. ${ }^{13}$, LARNER et al. $^{45}$, ALTAVILLA et al. ${ }^{6}$ e GÓES et al. ${ }^{33}$.

Uma maior freqüência de recidiva regional e metástase a distância foi detectada no grupo $\mathrm{CEB}$ em comparação ao grupo $\mathrm{CEC} / \mathrm{PD}$, sendo o pulmão o local mais comumente acometido pelas metástases de ambas as neoplasias. Nenhum paciente do grupo CEC/BD desenvolveu metástase a distância e a freqüência de recidiva regional neste grupo foi próxima àquela observada para o CEB (Tabela 5). Estes resultados confirmam os achados de COPPOLA et al. $^{28}$, GÓES et al. ${ }^{33}$ e WINZENBURG et al. ${ }^{90}$ que também verificaram os maiores índices de metástases a distância para o grupo CEB quando comparado com os carcinomas espinocelulares convencionais.

Esta maior freqüência de recidiva regional e/ou metástases a distância para os carcinomas escamosos basalóides quando comparados aos CECs da região de cabeça e pescoço, como observado por diversos autores ${ }^{13,28,30,33,40,45,90}$ incluindo o presente estudo, tem fornecido subsídios para reforçar o seu comportamento clínico mais agressivo.

A presença de um segundo tumor primário foi verificada em $17,7 \%$ dos pacientes do grupo CEB, valor este mais elevado que o observado por BANKS et al. ${ }^{13}$ Outros autores também relataram a ocorrência de CEB associados com segundos tumores primários sincrônicos ou metacrônicos ${ }^{30,52,64,68}$. Apenas quatro $(15,4 \%)$ pacientes portadores de 
carcinomas espinocelulares do grupo pouco diferenciado apresentaram também um segundo tumor primário.

Microscopicamente, os diferentes grupos tumorais estudados (CEB, CEC/PD e $\mathrm{CEC} / \mathrm{BD}$ ) foram determinados com base nas características celulares de malignidade e na organização tumoral.

Os aspectos morfológicos para a classificação do carcinoma escamoso basalóide seguiu-se basicamente os descritos por WAIN et al. ${ }^{82}$, sendo um requisito fundamental em nossa casuística a presença de células basalóides em mais de 80,0\% do componente tumoral.

O padrão sólido ou lobular (Figura 1) foi o mais freqüentemente observado e os padrões morfológicos tubular e cribiforme, descrito em outros estudos ${ }^{13,24,60,87}$ não foram encontrados na amostra estudada (Tabela 6).

Outras características morfológicas como disposição em paliçada das células periféricas das ilhotas tumorais (Figura 2), presença de comedonecrose, hialinização do estroma (Figura 1) e continuidade com a mucosa bucal (Figura 4), aspectos estes também descritos em diferentes estudos de CEBs da região de cabeça e $\operatorname{pescoço~}^{1,6,10,13,14,15,26,27,28,30,44,49,54,57,60,82,87,90}$, foram identificadas na maioria dos carcinomas escamosos basalóides.

A organização das células basalóides na forma de estruturas ductiformes estava presente em 23,5\% dos CEBs. Em 88,2\% destas neoplasias, foram observados espaços císticos sendo que 20,0\% destes eram PAS positivos, sugerindo a presença de depósitos mucóides ou muco-hialinos (Tabela 6 e Figura 3).

A identificação microscópica de espaços císticos com conteúdo PAS positivo e estruturas ductiformes como verificado no presente estudo e por outros autores ${ }^{6,14,15,28,30,49,57,87}$ 
pode dificultar, em boca, o diagnóstico entre CEB e tumores de origem glandular como o carcinoma adenóide cístico ${ }^{14,30,87}$.

Clinicamente, o diagnóstico diferencial entre CEB e carcinoma adenóide cístico é importante por razões terapêuticas e prognósticas e, segundo IDE et al. ${ }^{37}$, algumas características devem ser cuidadosamente observadas para a distinção microscópica destas duas neoplasias:

- o padrão cribiforme clássico é limitado quando presente no CEB;

- as estruturas tubulares no carcinoma adenóide cístico apresentam-se organizadas;

- o pleomorfismo nuclear, as mitoses e áreas necróticas são raras no carcinoma adenóide cístico;

- a diferenciação escamosa focal intercalada ao componente basalóide do CEB raramente é identificada no carcinoma adenóide cístico;

- o mais importante, o carcinoma adenóide cístico não contém focos de carcinoma espinocelular convencional ou alterações displásicas no epitélio de revestimento.

Outros aspectos microscópicos marcantes em nossa amostra foram a disjunção entre o epitélio tumoral e o tecido conjuntivo adjacente detectada em 76,5\% dos CEBs (Figura 1) e o componente escamoso associado ao basalóide, caracterizado principalmente por pérolas córneas e disqueratoses (Tabela 6 e Figura 4B).

A presença do componente escamoso intercalado ao basalóide, como observado em 76,5\% dos CEBs de nossa amostra (Tabela 6), tem sido descrita numa proporção variável dentro de um mesmo tumor, contudo isto reforça o diagnóstico de CEB nos diferentes sítios anatômicos $1,2,6,10,13,14,26,27,28,30,49,54,57,60,68,82,87,90$.

Devido a sua composição celular heterogênea, torna-se difícil ou quase impossível se estabelecer um diagnóstico de CEB baseando-se apenas em biópsias incisionais ${ }^{14,15}$. Portanto, 
quando realizado o diagnóstico de um carcinoma espinocelular pouco diferenciado por meio de uma biópsia incisional, a possibilidade de se tratar de um CEB não deve ser descartada ${ }^{2}$.

Para a classificação dos carcinomas espinocelulares com diferentes graus de diferenciação celular, utilizou-se o sistema de graduação histopatológica de malignidade proposto por BRYNE et al..$^{21}$ avaliando-se, principalmente, a área do front de invasão tumoral. Esta região tumoral foi escolhida para análise microscópica porque os eventos moleculares importantes para a disseminação tumoral como aquisição e perda de moléculas de adesão, secreção de enzimas proteolíticas, aumento da proliferação celular e angiogênese ocorrem essencialmente na interface tumor-hospedeiro ${ }^{20}$, ou seja, no front de invasão tumoral. Além disso, esta região apresenta maior valor prognóstico quando comparada com as demais áreas do tumor ${ }^{20}$.

A aplicação do sistema de graduação histopatológica de malignidade proposto por BRYNE et al. $^{21}$ em nossa amostra mostrou-se bastante fidedigna para a diferenciação dos carcinomas espinocelulares em bem a moderadamente e pouco diferenciados.

Como pode ser observado na Tabela 7 , os carcinomas espinocelulares bem a moderadamente diferenciados (Figura 5) apresentaram maior queratinização e os menores índices de pleomorfismo nuclear e número de mitoses, estatisticamente significativos $(\mathrm{p}<0,001)$, quando comparados aos CEC/PDs (Figura 6).

Um maior índice total de malignidade influenciado principalmente pelas variáveis queratinização, pleomorfismo nuclear e mitoses atípicas foi detectado nos tumores do grupo $\mathrm{CEC} / \mathrm{PD}$, definindo um comportamento mais agressivo para estas neoplasias (Tabela 7) comparativamente ao $\mathrm{CEC} / \mathrm{BD}$. 
O padrão de invasão infiltrativo (Figura 7) e o intenso infiltrado inflamatório mononuclear predominaram em ambos os grupos de carcinomas espinocelulares (CEC/PD e $\mathrm{CEC} / \mathrm{BD})$.

O perfil biológico mais agressivo do CEB em relação ao carcinoma espinocelular convencional tem sido associado a sua capacidade de invasão perineural, vascular, muscular e óssea, causando metástases regionais e a distância ${ }^{2,14,23,28,30,54,87}$. Em nosso estudo, embora uma freqüência maior de embolização vascular angiolinfática tenha ocorrido no grupo $\mathrm{CEC} / \mathrm{BD}$, quando comparada com os grupos $\mathrm{CEB}$ e CEC/PD, os maiores índices de metástase a distância foram detectados no CEB.

Por outro lado, a presença de infiltração perineural nos carcinomas espinocelulares convencionais (CEC/PD e CEC/BD) foi mais elevada sendo os índices estatisticamente significativos $(\mathrm{p}=0,004)$ quando comparados ao CEB (Tabela 8 e Figura 8). Isto provavelmente ocorreu devido ao padrão de invasão tumoral dos CECs caracterizado por células neoplásicas dispostas na forma de cordões grossos, cordões finos e/ou células isoladas sugerindo, microscopicamente, uma maior habilidade para infiltração tecidual e de estruturas adjacentes.

Os três grupos de carcinomas analisados (CEB, CEC/PD e CEC/BD) demonstraram freqüências semelhantes de infiltração muscular (Tabela 8 e Figura 5), entretanto, a infiltração óssea foi numericamente maior nos carcinomas espinocelulares pouco diferenciados (Tabela 8), comparativamente aos demais grupos (CEB e CEC/BD).

Além dos parâmetros clínicos e das características morfológicas de malignidade, outros aspectos como o índice de proliferação das células epiteliais neoplásicas e a expressão das moléculas de adesão celular são fundamentais para o delineamento do comportamento biológico tumoral. 
Geralmente, os carcinomas espinocelulares com altos índices de proliferação celular são associados com um pior prognóstico e uma resposta desfavorável à quimioterapia e à radioterapia ${ }^{91}$. A expressão dos marcadores imuno-histoquímicos de proliferação celular como PCNA e Ki-67/MIB-1 são comumente investigados e, algumas vezes, correlacionados com os índices de sobrevida dos pacientes com CECs e CEB ${ }^{78,69}$.

Em nossa amostra, um maior índice de proliferação celular determinado pela imunopositividade ao PCNA com valores superiores a 61,0\% foi verificado numericamente no $\mathrm{CEB}$ quando comparado ao $\mathrm{CEC} / \mathrm{PD}$ e $\mathrm{CEC} / \mathrm{BD}$ (Figuras 9 e 10). Entretanto, ao compararmos estatisticamente os três grupos de carcinomas, nenhuma diferença entre os valores correspondentes à imunoexpressão do PCNA foi obtida, sugerindo uma atividade proliferativa semelhante entre o CEB, o CEC/PD e o CEC/BD (Tabela 9).

Como pode ser visualizado na Figura 9, a imunopositividade ao PCNA no CEB estava restrita às regiões periféricas das ilhotas tumorais, sendo as células basalóides próximas às áreas centrais de comedonecrose negativas para o PCNA. De forma semelhante, nos carcinomas espinocelulares, as pérolas córneas e áreas focais de queratinização também foram negativas para o PCNA (Figura 10).

Nossos resultados reforçam a afirmativa de que, mesmo com a heterogeneidade das células tumorais presente nos carcinomas espinocelulares, as regiões de células malignas bem diferenciadas e com baixa atividade mitótica podem ser distinguidas das regiões com células pobremente diferenciadas e alta taxa de proliferação ${ }^{38}$.

Ressaltamos ainda que nenhuma correlação estatisticamente significativa foi obtida entre a expressão de PCNA nos grupos tumorais estudados e as características clínicas (estadiamento T e N, localização, tipo de lesão, recidiva local, recidiva regional e metástase a distância) e os aspectos microscópicos (queratinização, pleomorfismo nuclear, número de 
mitoses, infiltrado inflamatório, embolização vascular e infiltrações perineural, muscular e óssea (Tabelas 10 e 11). Apenas o padrão de invasão infiltrativo foi predominante e estatisticamente significativo $(p=0,028)$ sobre o padrão de invasão compressivo nos carcinomas espinocelulares (CEC/PD e CEC/BD).

Estes resultados demonstram que a porcentagem de células PCNA positivas no front de invasão tumoral dos carcinomas espinocelulares não é influenciada pelo grau de diferenciação celular, reforçando os achados de e ALLISON; BEST ${ }^{5}$ e TSAI; JIN ${ }^{78}$.

Outro aspecto investigado no presente estudo consistiu na análise da expressão das moléculas de adesão celular E-caderina e $\beta$-catenina, responsáveis pela manutenção das uniões intercelulares associadas ao processo de invasão tumoral e disseminação metastática nos carcinomas espinocelulares.

A redução ou perda da expressão do complexo E-caderina/catenina via mutações ou perda da heterozigose apresenta-se freqüente durante a carcinogênese, afetando sua atividade supressora tumoral $^{16,34,36,71,88}$. De modo geral, a imunomarcação de caderinas e cateninas tem sido verificada mais intensamente nos carcinomas espinocelulares bem diferenciados, que mantêm sua adesividade celular e são menos invasivos, quando comparada com os carcinomas pouco diferenciados com padrão de invasão infiltrativo e pouca ou nenhuma coesão celular ${ }^{9,25,47,59,62,92}$.

Em nosso estudo, a perda ou redução da expressão de E-caderina foi observada em mais de $80 \%$ dos carcinomas dos grupos CEB e CEC/PD (Tabela 9 e Figuras 12B e 13B). No grupo $\mathrm{CEC} / \mathrm{BD}$, a forte expressão membranosa de E-caderina foi semelhante àquela identificada na mucosa bucal normal (Figura 11) e, quando comparada aos demais grupos tumorais (Tabela 9), esta expressão foi estatisticamente significativa $(p=0,019)$. 
Ao correlacionarmos a imunoexpressão de E-caderina com as características clínicas estadiamentos T e N, localização, tipo de lesão, recidiva local, recidiva regional e metástase a distância nos grupos tumorais analisados, nenhuma diferença estatisticamente significativa foi obtida (Tabela 12).

Embora alguns autores ${ }^{31,62,92}$ tenham associado a perda ou redução da expressão de Ecaderina em carcinomas espinocelulares com uma maior freqüência de metástase regional, no presente estudo esta associação não foi verificada nos diferentes carcinomas espinocelulares e escamoso basalóide de boca.

Entretanto, em relação aos aspectos microscópicos, a forte expressão de E-caderina nos carcinomas espinocelulares (CEC/BD) correlacionou-se significativamente apenas com a alta queratinização, o baixo pleomorfismo nuclear, o baixo número de mitoses e um menor índice total de malignidade (Tabela 13), características estas que definem um maior grau de diferenciação e um fenótipo menos agressivo dos carcinomas espinocelulares bem a moderadamente diferenciados.

Os resultados acima descritos corroboram com os estudos de ANDREWS et al. ${ }^{7}$, BAGUTTI et al. ${ }^{9}$, BOWIE et al. ${ }^{17}$, FRANCHI et al. ${ }^{31}$, LIM et al. ${ }^{46}$, SAKAKI et al. ${ }^{59}$, SCHIPPER et al. ${ }^{62}$, TANAKA et al. ${ }^{76}$ e YAMADA et al. ${ }^{92}$, que também verificaram uma redução ou perda de expressão de E-caderina nos carcinomas espinocelulares pouco diferenciados da região de cabeça e pescoço. Contrariando estes resultados, de acordo com as evidências relatadas por CHOW et al. $^{25}$ e SHINOHARA et al. ${ }^{67}$, não houve nenhuma correlação de E-caderina com o grau de diferenciação celular em carcinomas espinocelulares de boca.

A expressão de E-caderina tem sido pouco investigada em carcinomas escamosos basalóides da região de cabeça e pescoço. Nossos resultados confirmam aqueles encontrados 
por TSUBOCHI et al. ${ }^{79}$ que observaram uma redução da expressão de E-caderina em todos os sete CEBs por eles avaliados, reiterando o comportamento agressivo desse tumor.

De forma semelhante à E-caderina, uma expressão predominantemente membranosa de $\beta$-catenina nas células epiteliais neoplásicas malignas foi verificada principalmente no grupo $\mathrm{CEC} / \mathrm{BD}$ (Figura 14A). Nos CEBs, assim como nos CEC/PDs, a expressão de $\beta$ catenina quando presente era irregular e essencialmente citoplasmática (Figuras 14B e 15).

A perda ou redução da expressão de $\beta$-catenina foi detectada numericamente em mais de $70,0 \%$ dos carcinomas espinocelulares e em 58,8\% dos CEBs, entretanto, nenhuma diferença estatisticamente significativa foi detectada ao comparar a expressão desta molécula de adesão celular entre os três grupos tumorais analisados (Tabela 9).

Estes resultados reforçam os de LOPEZ-GONZALES et al. ${ }^{48}$ que também verificaram uma maior redução da imunomarcação membranosa da $\beta$-catenina em carcinomas pouco diferenciados quando comparados aos bem a moderadamente diferenciados de laringe. Estes autores sugeriram que a disfunção da $\beta$-catenina causada pela sua expressão membranosa reduzida e seu acúmulo citoplasmático, porém não nuclear, em carcinomas espinocelulares pouco diferenciados de laringe reflete um aumento na taxa de degradação celular desta molécula de adesão.

Nenhuma correlação, estatisticamente significativa, foi detectada entre a $\beta$-catenina e as características clínicas incluindo estadiamentos T e N, localização, tipo de lesão, recidivas local e regional e metástase a distância nos grupos CEB, CEC/PD e CEC/BD como pode ser visualizado na Tabela 12.

Também em relação aos aspectos microscópicos (Tabela 13), a expressão de $\beta$ catenina não foi significativamente correlacionada com a queratinização, o pleomorfismo 
nuclear, o número de mitoses, o padrão de invasão, o infiltrado inflamatório mononuclear, o índice total de malignidade, embolização vascular e infiltrações perineural e óssea. Uma correlação estatisticamente significativa $(p=0,030)$ foi obtida entre a expressão de $\beta$-catenina e a presença de infiltração muscular (Tabela 13).

Como as cateninas têm um papel crítico no controle da adesão celular mediada pela Ecaderina, isto indica que a imunorreatividade nem sempre implica na presença de um complexo E-caderina/catenina funcionalmente normal ${ }^{88}$. Portanto, como realizado no presente estudo e também por outros autores ${ }^{7,9,11,25,46,76,89,94,}$, a influência destas moléculas no processo de invasão e metástase deve ser analisada em conjunto.

Os nossos resultados relativos à expressão do complexo E-caderina/ $\beta$-catenina nos carcinomas espinocelulares e escamoso basalóide de boca reforçam os achados de BAGUTTI; SPEIGHT; WATT $^{9}$ que identificaram uma correlação entre a expressão de E-caderina e o grau de diferenciação dos carcinomas espinocelulares de boca, porém não conseguiram associar a expressão reduzida de $\beta$-catenina com o grau de diferenciação tumoral.

A utilização de marcadores imuno-histoquímicos relacionados à proliferação celular e das moléculas de adesão celular E-caderina e $\beta$-catenina geralmente foi investigada como complemento dos parâmetros clínicos e morfológicos tumorais.

Uma das principais variáveis utilizada na determinação do prognóstico dos carcinomas espinocelulares da cavidade bucal consiste no comprometimento de linfonodos regionais e de metástase a distância.

Em nosso estudo, nenhuma correlação estatisticamente significativa entre a imunoexpressão dos marcadores PCNA, E-caderina e $\beta$-catenina e a presença de metástases em linfonodos regionais confirmada microscopicamente $(\mathrm{pN}+)$ foi detectada nos três grupos de carcinomas avaliados, como demonstrado na Tabela 14. 
O processo metastático é resultado da aquisição progressiva de um comportamento agressivo das células neoplásicas, caracterizado por um aumento nos índices de proliferação e uma modificação das propriedades adesivas destas células associadas a alterações genéticas ${ }^{31}$. Em carcinomas espinocelulares de laringe, de acordo com FRANCHI et al. ${ }^{31}$, a alta atividade proliferativa determinada pela imunomarcação do MIB-1 e do PCNA e a redução ou perda da expressão de E-caderina correlacionou-se significativamente com a presença de metástases em linfonodos regionais. Como conclusões, estes autores afirmaram que a diminuição da adesão célula-célula no tecido neoplásico maligno pode estar relacionada não apenas às propriedades invasivas e metastáticas, mas também ao índice de proliferação das células neoplásicas.

Outros estudos ${ }^{11,46,51,62,67,76,89}$ também demonstraram uma correlação positiva entre a redução ou perda de expressão das moléculas de adesão celular E-caderina e $\beta$-catenina e o desenvolvimento de metástases em linfonodos regionais em pacientes portadores de carcinomas espinocelulares da região de cabeça e pescoço, embora resultados conflitantes tenham sido apresentados por BOWIE et al. ${ }^{17}$ e ANDREWS et al. ${ }^{7}$, que não conseguiram estabelecer esta correlação entre as moléculas de adesão celular e a presença de metástases linfonodais.

Assim como WILLIANS et al. ${ }^{89}$, concordamos que o valor da redução ou perda da expressão de E-caderina e $\beta$-catenina como um marcador biológico para a disseminação metastática ou como um indicador de prognóstico para os pacientes portadores de carcinomas espinocelulares de boca necessita ser melhor avaliado.

A influência da morfologia tumoral no prognóstico dos pacientes portadores de CEB, $\mathrm{CEC} / \mathrm{PD}$ e $\mathrm{CEC} / \mathrm{BD}$ revelou um prognóstico similar entre estes pacientes, delineados pelas análises de sobrevida global e livre de doença (Figuras 16 e 17). Nenhuma diferença 
estatisticamente significativa entre estas taxas de sobrevida foi verificada nos pacientes dos três grupos tumorais, independentemente das marcações imuno-histoquímicas (Tabelas 15 e 16).

A influência da redução ou perda da expressão das moléculas de adesão celular Ecaderina e $\beta$-catenina na sobrevida dos pacientes com carcinomas espinocelulares apresenta resultados divergentes na literatura. Enquanto TANAKA et al. ${ }^{76}$ e ZHAO et al. ${ }^{94}$ observaram uma significativa correlação entre a redução ou perda da expressão de E-caderina e $\beta$-catenina em carcinomas espinocelulares de boca e esôfago e a diminuição dos índices de sobrevida global, nos estudos de BÁNKFALVI et al. ${ }^{11}$, CHOW et al. ${ }^{25}$ e LIM et al. ${ }^{46}$, estes marcadores imuno-histoquímicos não influenciaram a sobrevida global e livre de doença dos pacientes portadores de CEC localizados em boca.

BÁNKFALVI et al. ${ }^{11}$ afirmaram que o real valor prognóstico destas moléculas de adesão celular no carcinomas espinocelulares de boca requer maiores verificações em casuísticas que possam abranger carcinomas espinocelulares em estádios clínicos iniciais, visando uma redução da influência de eventos genéticos e fenotípicos irrelevantes.

Os pacientes com carcinoma escamoso basalóide e com carcinomas espinocelulares bem a moderadamente e pouco diferenciados de boca do presente estudo apresentaram, no momento do diagnóstico, estadiamento clínico avançado associado com uma alta freqüência de comprometimento dos linfonodos regionais.

A variável de estudo $\mathrm{N}$ constituiu fator independente indicativo de prognóstico desfavorável nos três grupos de carcinomas estudados. O risco relativo de morte para os pacientes com comprometimento linfonodal $(\mathrm{N}+)$ no momento do diagnóstico foi de 2,16 vezes maior comparativamente aos pacientes sem comprometimento linfonodal (N0) 
$(\mathrm{p}=0,025)$, independentemente da idade, gênero, grupo tumoral e positividade aos marcadores E-caderina, $\beta$-catenina e PCNA.

Os resultados do presente estudo não suportam as afirmativas relativas ao comportamento clínico e biológico mais agressivo do carcinoma escamoso basalóide quando comparado ao carcinoma espinocelular. As análises clínicas e imuno-histoquímicas referentes à expressão de PCNA, E-caderina e $\beta$-catenina sugerem que o tipo histológico e o grau de diferenciação celular dos CECs, CEC/PDs e CEC/BDs, quando pareados pelo estadiamento clínico e localização, não influenciam o prognóstico dos pacientes. Entretanto, para confirmação destes resultados, outros estudos comparativos entre os CECs de diferentes graduações histopatológicas e suas variantes são necessários. 
7 CONCLUSÕES 


\section{CONCLUSÕES}

A análise das características clínicas e microscópicas dos 17 pacientes portadores de carcinomas escamosos basalóides, dos 26 portadores de carcinomas espinocelulares pouco diferenciados e dos 28 carcinomas espinocelulares bem a moderadamente diferenciados revelou:

$\checkmark$ uma predominância de pacientes do gênero masculino, da raça branca, com idade média de 58 anos, tabagistas, etilistas e com estádios clínicos avançados (III e IV) no momento do diagnóstico;

$\checkmark$ uma maior freqüência de tumores do grupo CEB localizados no soalho bucal e dos grupos CECs na região retromolar/gengiva, sendo a maioria das lesões ulceroinfiltrativas;

que a maioria dos pacientes se submeteu à excisão cirúrgica e esvaziamento cervical como tratamento inicial, com exceção de um paciente do grupo CEC/BD não esvaziado;

$\checkmark$ que a radioterapia pós-operatória complementar foi indicada em mais de $80,0 \%$ dos pacientes com CEB e CEC/PD e em 64,3\% dos pacientes com CEC/BD; aproximadamente $20,0 \%$ dos pacientes dos três grupos estudados foram submetidos à quimioterapia pós-operatória;

$\checkmark$ uma maior freqüência de recidiva local nos pacientes do grupo CEC/PD, enquanto que a recidiva regional, metástases a distância e o desenvolvimento de um segundo tumor primário ocorreram principalmente nos CEBs;

$\checkmark$ que a maioria dos CEBs apresentava, microscopicamente, continuidade com a mucosa bucal, uma configuração tumoral sólida/lobular com disposição das células periféricas em 
paliçada, perda das pontes intercelulares, comedonecrose, espaços císticos, disjunção tumor-conjuntivo e presença de componente escamoso;

$\checkmark$ uma maior queratinização, menor pleomorfismo nuclear, menor número de figuras de mitoses atípicas e menor índice total de malignidade nos tumores do grupo CEC/BD quando comparados aos do grupo CEC/PD ( $<<0,001)$;

$\checkmark$ que a maioria dos tumores dos grupos CEB, CEC/PD e CEC/BD apresentava infiltração muscular e ausência de embolização angiolinfática;

$\checkmark$ uma maior ocorrência de infiltração óssea no grupo CEC/PD quando comparado aos grupos $\mathrm{CEB}$ e $\mathrm{CEC} / \mathrm{BD}$;

$\checkmark$ uma maior freqüência de infiltração perineural nos CECs quando comparada ao grupo $\operatorname{CEB}(p=0,004)$

$\checkmark$ não houve diferença estatisticamente significativa entre os três grupos estudados (CEB, CEC/PD e CEC/BD) nos índices de proliferação celular determinados pela imunopositividade ao PCNA;

$\checkmark$ uma redução ou ausência da expressão da molécula de adesão E-caderina em mais de $80,0 \%$ dos tumores dos grupos CEB e CEC/PD, estatisticamente significativa $(p=0,019)$, quando comparada ao grupo $\mathrm{CEC} / \mathrm{BD}(53,6 \%)$;

$\checkmark$ uma forte expressão da molécula de adesão celular $\beta$-catenina em $26,9 \%$ e em $20,8 \%$ dos tumores dos grupos CEC/BD e CEC/PD respectivamente, e em 41,2\% dos tumores do grupo CEB;

que a expressão dos marcadores imuno-histoquímicos PCNA, E-caderina e $\beta$-catenina não constituíram fatores de prognóstico para os pacientes portadores de CEB, CEC/PD e $\mathrm{CEC} / \mathrm{BD}$, sendo as probabilidades de sobrevida global e livre de doença acumuladas em 5 e 10 anos semelhantes para os três grupos avaliados; 
que o estadiamento clínico $\mathrm{N}$ foi o único fator de prognóstico independente para os pacientes portadores de CEB, CEC/PD e CEC/BD localizados exclusivamente em boca.

Portanto, baseados nestes resultados, podemos concluir que o comportamento clínico e biológico do carcinoma escamoso basalóide e dos carcinomas espinocelulares bem, moderadamente e pouco diferenciados localizados em língua, soalho bucal, gengiva inferior e região retromolar são semelhantes, não sendo influenciados pelo grau de diferenciação celular e/ou pela variante microscópica quando estas neoplasias apresentam estadiamentos clínicos avançados. Além disso, reiteramos que o comprometimento linfonodal consiste em uma das mais consistentes variáveis para o delineamento da evolução clínica e a determinação do prognóstico nos pacientes com carcinomas espinocelulares de boca. 
ANEXXOS 
ANEXO 1 - Ficha utilizada para a coleta dos dados clínicos e microscópicos relativos aos pacientes com carcinoma escamoso basalóide e com carcinomas espinocelulares pouco diferenciado e bem a moderadamente diferenciado

Formulário para a coleta de dados

\section{Faculdade de Odontologia de Bauru / USP}

Departamento de Estomatologia- Área de Patologia

Fundação Antônio Prudente/ Hospital do Câncer

Departamento de Anatomia Patológica

Departamento de Cirurgia de Cabeça e Pescoço e Otorrinolaringologia

“Expressão de PCNA, E-caderina e $\beta$-catenina em carcinomas espinocelulares e escamoso basalóide de boca: correlação com o comportamento clínico e prognóstico"

João Adolfo Costa Hanemann; Prof. ${ }^{a}$ Dr $^{a}$. Denise Tostes Oliveira; Dr. Gilles Landman;

Prof. Dr. Luiz Paulo Kowalski e Dr ${ }^{a}$. Fernanda Costa Grizzo de Sampaio Góes

I. Identificação e dados demográficos:

1. Número no estudo:

2. RGH:

3. Idade: anos

4. Gênero: $\square$ 1-masculino $\square$ 2-feminino

5. Raça: $\square$ 1-branca $\square$ 2-amarela $\square$ 3-negra $\square$ 4-outra

6. Residência: $\square$ 1-capital $\square$ 2-outra cidade de São Paulo $\square$ 3-outro estado

II. História clínica:

7. Tempo de história: meses (999 se desconhecido)

8. Tabagismo: $\square$ 0-não $\square$ 1-+ $\square$ 2-++ $\square$ 3-+++ $\square$ 4-++++ $\square$ 9-desc.

9. Etilismo: $\square$ 0-não $\square$ 1-+ $\square$ 2-++ $\square$ 3-+++ $\square$ 4- ++++ $\square$ 9-desc.

III. Loco-regional:

10. Local de tumor: $\square$ 1-ponta da língua $\square$ 2-corpo de língua lingual $\square$ 5-assoalho $\square$ 6-gengiva inferior $\square$ 7-retromolar

3-ponta e corpo de língua

4-sulco pelve

11. Tipo de lesão: $\square$ 1-úlcero-vegetante

2-úlcero-infiltrativa

3-outra

12. Estádio T (atualizar UICC 87):

$\square 1-\mathrm{T} 1$

$\square$ 2-T2

$\square$ 3-T3

$\square$ 4-T4

$\square$ 9-Tx

13. Estádio N (atualizar UICC 87):

0-N0

$\square$ 1-N1 $\square$ 2-N2a

$3-\mathrm{N} 2 \mathrm{~b}$

$\square$ 4-N2c

5-N3

IV. Cirurgia: 
14. Data da cirurgia:

15. Cirurgia tumor primário: $\square$ 1- cirurgia sem esvaziamento cervical $\square$ 2- cirurgia com esvaziamento cervical ipsilateral $\square$ 3- cirurgia com esvaziamento cervical contralateral (simultâneo)

16. Data da alta hospitalar:

\section{Radioterapia pós-operatória:}

17

$\square$ 0- não $\square$ 1- sim

\section{Quimioterapia pós-operatória}
18
$\square$ 0- não
$1-\operatorname{sim}$

\section{Anatomopatológico da peça da cirurgia inicial:}

19. Número do AP:

20. Histologia do t. primário: $\square$ 1-CEC I $\square$ 2-CEC II $\square$ 3-CEC III $\square$ 4-CEB $\square$ 5-Ca Indiferenciado

21. COMPONENTE BASALÓIDE: $\square$ 0-ausente $\square$ 1-presente $\%$ observado no espécime

22. Padrão do tumor: $\square$ 1-sólido $\square$ 2-lobular $\square$ 3-trabecular $\square$ 4-cribiforme

23. Continuidade com a mucosa bucal: $\square$ 0-ausente $\square$ 1-presente $\square$ 2-não observada a mucosa bucal

24. Disposição em paliçada: $\square$ 0-ausente $\square$ 1-presente

25. Pontes intercelulares: $\square$ 0-ausente $\square$ 1-presente

26. Figuras de mitoses: $\square$ 0-ausente $\square$ 1-presente

27. Espaços císticos: $\square$ 0-ausente $\square$ 1-presente

28. Espaços císticos PAS positivos: $\square$ 0-ausente $\square$ 1-presente

29. Necrose central por coagulação: $\square$ 0-ausente $\square$ 1-presente $\%$ observado no espécime

30. Hialinização: $\square$ 0-ausente $\square$ 1-intratumoral $\square$ 2-peritumoral $\square$ 3-ambos

31. Hialinização do intratumoral: $\square$ 1-focal $\square$ 2-difusa

32. Hialinização peritumoral: $\square$ 1-focal $\square$ 2-difusa

33. IM ao anticorpo PCNA: $/ \mathrm{mm}^{2}$

34. IM ao anticorpo E-caderina: $/ \mathrm{mm}^{2}$

35. IM ao anticorpo $\beta$-catenina: $/ \mathrm{mm}^{2}$

36. COMPONENTE ESCAMOSO: $\square$ 0-ausente $\square$ 1-presente $\%$ observado no espécime

37. Componente escamoso: $\square$ 1-Ca in situ $\square$ 2-CEC $\square$ 3-CA indif.

38. Ca Espinocelular - Pérolas córneas: $\square$ 0-ausente $\square$ 1-presente

39. Ca Espinocelular - Disqueratose: $\square$ 0-ausente $\square$ 1-presente

40. Ca Espinocelular - Pontes intercelulares: $\square$ 0-ausente $\square$ 1-presente

41. Ca Espinocelular - Figuras de Mitoses: $\square$ 0-ausente $\square$ 1-presente

42. Ca Espinocelular - Hipercromatismo: $\square$ 0-leve $\square$ 1-moderado $\square$ 2-intenso

43. Ca Espinocelular - Pleomorfismo: $\square 0$ leve $\square$ 1-moderado $\square$ 2-intenso

44. IM ao anticorpo PCNA: $/ \mathrm{mm}^{2}$

45. IM ao anticorpo E-caderina: $/ \mathrm{mm}^{2}$

46. IM ao anticorpo $\beta$-catenina: $/ \mathrm{mm}^{2}$ 

47. Embolização vascular: $\square$ 0-não
1-linfática
$\square$ 2-sangüínea
3-ambas
9-ign.
48. Infiltração perineural: $\square 0$-não
1-presente
$\square$ 9-ignorado
49. Infiltração muscular: $\square$ 0-não
$\square$ 1-presente
$\square$ 9-ignorado
50. Infiltração óssea: $\square$ 0-não $\square$ 1-presente $\square$ 9-ignorado
51. Margens: $\square$ 0-livres $\square$ 1-presente $\square$ 2-comprometidas $\square$ 9-ign.

52. Linfonodos comprometidos (patológico): $\square$ 0-não $\square$ 1-presente $\square$ 9-ignorado

\section{Evolução:}

53. Data da primeira recidiva:

54. Locais de recidiva: $\square$ 0-não teve $\square$ 1-local $\square$ 2-pescoço ipsi $\square$ 6-fígado $\square$ 7-outra à distância (perdido de vista assintomático $<5$ anos)

55. Data do diagnóstico do segundo tumor primário: (0/0/0 se não teve)

56. Local do segundo tumor primário: CID-O (0 se não teve)

57. Data da última informação objetiva de seguimento:

58. Situação na última informação de seguimento: $\square$ 5-MOASS

$\square$ 1-vivo 000

2-vivo com CA

3-MOCI

4-MOCA vista (definição: para pacientes com menos de 5 anos de seguimento todos os que deixaram de retornar por um período igual ao dobro estipulado. Pacientes assintomáticos perdidos após 5 anos devem ser classificados como vivos 000)

OBS: Para pacientes perdidos de vista: anotar nome, endereço e telefone. Entregar o prontuário aos responsáveis pela convocação de pacientes esta lista diariamente. 
REFERÊTSCIAS BIBLIOGRÁFICAS 


\section{REFERÊNCIAS BIBLIOGRÁFICAS*}

1. ABIKO, Y. et al. Basaloid-squamous cell carcinoma of the floor of the mouth: characterization of a cell line. J Oral Pathol Med, v.26, n.8, p.367-70, Sept. 1997.

2. ABIKO, Y. et al. Basaloid-squamous cell carcinoma of the oral mucosa: report of two cases and study of the proliferative activity. Pathol Int, v.48, n.6, p.460-6, June 1998.

3. AKYOL, M.U. et al. Proliferating cell nuclear antigen immunoreactivity and the presence of p53 mutation in basaloid squamous cell carcinoma of the larynx. Oncology, v.55, n.5, p.382-3, Sept. 1998.

4. ALBELDA, S.M. Role of integrins and other cell adhesion molecules in tumor progression and metastasis. Lab Invest, v.68, n. 1, p.4-17, Jan. 1993.

5. ALLISON, R.T.; BEST, T. p53, PCNA and Ki-67 expression in oral squamous cell carcinomas: the vagaries of fixation and microwave enhancement of immunohistochemistry. J Oral Pathol Med, v.27, n.9, p.434-40, Oct. 1998.

6. ALtAVILLA, G. et al. Basaloid squamous cell carcinoma of the oral cavity and oropharynx. ORL J Otorhinolaryngol Relat Spec, v.61, n.3, p.169-73, May/June 1999.

7. ANDREWS, N.A. et al. Expression of the E-cadherin-catenin cell adhesion complex in primary squamous cell carcinomas of the head and neck and their nodal metastases. Br J Cancer, v.75, n.10, p.1474-80, 1997.

8. BAAK, J.P.A. Mitosis couting in tumors. Human Pathol, v.21, n.7, p.683-5, July 1990.

9. BAGUTTI, C.; SPEIGHT, P.M.; WATT, F.M. Comparison of integrin, cadherin, and catenin expressin in squamous cell carcinomas of the oral cavity. J Pathol, v.186, n.1, p.8-16, Sept. 1998.

10. BAHAR, G. et al. Basaloid squamous carcinoma of the larynx. Am J Otolaryngol, v.24, n.3, p.203-8, May/June 2003.

\footnotetext{
* Normas recomendadas para o uso no âmbito da Universidade de São Paulo, com base no documento "Referências Bibliográficas: exemplos" emanado do Conselho Supervisor do Sistema de Bibliotecas da USP, em reunião de 20 de setembro de 1990.
} 
11. BÁNKFALVI, A. et al. Gains and losses of adhesion molecules (CD44, E-cadherin, and $\beta$-catenin) during oral carcinogenesis and tumour progression. J Pathol, v.198, n.3, p. 343-51, Nov. 2002.

12. BANKS, E.R.; FRIERSON JR., H.F.; COVELL, J.L. Fine needle aspiration cytologic findings in metastatic basaloid squamous cell carcinoma of the head and neck. Acta Cytol, v.36, n.2, p.126-31, Mar./Apr. 1992.

13. BANKS, E.R. et al. Basaloid squamous cell carcinoma of the head and neck- a clinicopathologic and immunohistochemical study of 40 cases. Am J Surg Pathol, v.16, n.10, p.939-46, Oct. 1992.

14. BARNES, L. et al. Basaloid squamous cell carcinoma of the head and neck: clinicopathological features and differential diagnosis. Ann Otol Rhinol Laryngol, v.105, n.1, p.75-82, Jan. 1996.

15. BATSAKIS, J.G.; EL NAGGAR, A. Basaloid-squamous carcinomas of the upper aerodigestive tracts. Ann Otol Rhinol Laryngol, v.98, n.11, p.919-20, Nov. 1989.

16. BEAVON, I.R.G. The E-cadherin-catenin complex in tumour metastasis: structure, function and regulation. Eur J Cancer, v.36, n.13, p.1607-20, Aug. 2000.

17. BOWIE, G.L. et al. Expression of the cell-cell adhesion molecule E-cadherin in squamous cell carcinoma of the head and neck. Clin Otolaryngol, v.18, n.3, p.196-201, June 1993.

18. BRAVO, R. Et al. Cyclin/PCNA is the auxiliary protein of DNA polymerase- $\delta$. Nature, v.326, n.6112, p.515-7, Apr. 1987.

19. BRODERS, A.C. Squamous-cell epithelioma of the lip- a study of five hundred and thirty-seven cases. JAMA, v.74, n.10, p.656-64, Mar. 1920.

20. BRYNE, M. Is the invasive front of an oral carcinoma the most important area for prognostication? Oral Dis, v.4, n.2, p.70-7, June 1998.

21. BRYNE, M. et al. New malignancy grading is a better prognostic indicator than Broders' grading in oral squamous cell carcinomas. J Oral Pathol Med, v.18, n.8, p.432-7, Sept. 1989.

22. CADIER, M.A. et al. Basaloid squamous carcinoma of the buccal cavity. Head Neck, v.14, n.5, p.387-91, Sept./Oct. 1992. 
23. CAMPMAN, S.C.; GANDOUR-EDWARDS, R.F.; SYKES, J.M. Basaloid squamous carcinoma of the head and neck- report of a case occurring in the anterior floor of the mouth. Arch Pathol Lab Med, v.118, n.12, p.1229-32, Dec. 1994.

24. CHO, K.J. et al. Basaloid squamous carcinoma of the oesophagus: a distinct neoplasm with multipotential differentiation. Histopathology, v.36, n.4, p.331-40, Apr. 2000.

25. CHOW, V. et al. A comparative study of the clinicopathological significance of Ecadherin and catenins $(\alpha, \beta, \gamma)$ expression in the surgical management of oral tongue carcinoma. J Cancer Res Clin Oncol, v.127, n.1, p.59-63, Jan. 2001.

26. COLETTA, R.D. et al. Basaloid squamous carcinoma of the oral cavity: report of 2 cases and study of AgNOR, PCNA, p53, and MMP expression. Oral Surg Oral Med Oral Pathol Oral Radiol Endod, v.91, n.5, p.563-9, May 2001.

27. COLETTA, R.D. et al. Basaloid squamous carcinoma of the oral cavity: a histologic and immunohistochemical study. Oral Oncol, v.38, n.7, p.723-9, Oct. 2002.

28. COPPOLA, D. et al. Basaloid squamous cell carcinoma of the floor of mouth. Cancer, v.72, n.8, p.2299-305, Oct. 1993.

29. COUTURE, C. et al. p53 and Ki-67 as markers of radioresistence in head and neck carcinoma. Cancer, v.94, n.3, p.713-22, Feb. 2002.

30. FERLITO, A. et al. Basaloid squamous cell carcinoma of the larynx and hipopharynx. Ann Otol Rhinol Laryngol, v.106, n.12, p.1024-35, Dec. 1997.

31. FRANCHI, A. et al. Prediction of occult neck metastases in laryngeal carcinoma: role of proliferating cell nuclear antigen, MIB-1, and E-cadherin immunohistochemical determination. Clin Cancer Res, v.2, n.10, p.1801-8, Oct. 1996.

32. GÓES, F.C.G.S. Carcinoma escamoso basalóide na mucosa bucal: comportamento clínico, prognóstico e análise da expressão de PCNA, p53, Bax e Bcl-X. Bauru 2003. Tese (Doutorado)- Universidade de São Paulo, Faculdade de Odontologia de Bauru.

33. GÓES, F.C.G.S. et al. Prognoses of oral basaloid squamous cell carcinoma and squamous cell carcinoma- a comparison. Arch Otolaryngol Head Neck Surg, v.130, n.1, p. 836, Jan. 2004.

34. HAJRA, K.M.; FEARON, E.R.. Cadherin and catenin alterations in human cancer. Genes Chromosomes Cancer, v.34, n.3, p.255-68, July 2002 
35. HANNEN, E.J.M. et al. An image analysis study on nuclear morphology in metastasized and non-metastasized squamous cell carcinomas of the tongue. J Pathol, v.185, n.2, p.175-83, June 1998.

36. HIROHASHI, S.; KANAI, Y. Cell adhesion system and human cancer morphogenesis. Cancer Sci, v.94, n.7, p.575-81, Jul. 2003.

37. IDE, F. et al. Basaloid squamous cell carcinoma of the oral mucosa: a new case and review of 45 cases in the literature. Oral Oncol, v.38, n.1, p.120-4, Jan. 2002.

38. JACOB, R. et al. Heterogeneity of squamous cell carcinomas of the head and neckanalysis of tumor biologic factors and proliferation rates. Laryngoscope, v.106, n.9, p.1170-5, Sept.1996.

39. KEMLER, R. From cadherins to catenins: cytoplasmic protein interactions and regulation of cell adhesion. Trends Genet, v.9, n.9, p.317-21, Sept. 1993.

40. KLIJANIENKO, J. et al. Basaloid squamous cell carcinoma of the head and neckimmunohistochemical comparision with adenoid cystic carcinoma and squamous cell carcinoma. Arch Otolaryngol Head Neck Surg, v.119, n.8, p.887-90, Aug. 1993.

41. KOELBL, O. et al. p53 and Ki-67 as predictive markers for radiosensitivity in squamous cell carcinoma of the oral cavity? An immunohistochemical and clinicopathologic study. Int J Radiation Oncol Biol Phys, v.49, n.1, p.147-54, Jan. 2001.

42. KOWALSKI, L.P. et al. Factors influencing contralateral lymph node metastasis from oral carcinoma. Head Neck, v.21, n.2, p.104-10, Mar. 1999.

43. KUNKEL, M. et al. Surveillance of basaloid oral squamous cell carcinoma: the value of $\left[{ }^{18}\right.$ F]FDG-PET. Oral Oncol, v.40, n.1, p.56-62, Jan. 2004.

44. LAM, K.Y. et al. Oesophageal basaloid squamous cell carcinoma: a unique clinicopathological entity with telomerase activity as a prognostic indicator. J Pathol, v.195, n.4, p.435-42, Nov. 2001.

45. LARNER, J.M. et al. Radiotherapy for basaloid squamous cell carcinoma of the head and neck. Head Neck, v.15, n.3, p.249-52, May/June 1993.

46. LIM, S.C. et al. Predictive markers for late cervical metastasis in stage I and II invasive squamous cell carcinoma of the oral tongue. Clin Cancer Res, v.10, n.1, p.166-72, Jan 2004.

47. LO MUZIO, L. et al. Beta- and Gamma-catenin expression in oral squamous cell carcinomas. Anticancer Res, v.19, n.5B, p.3817-26, Sept./Oct. 1999. 
48. LOPEZ-GONZALEZ, J.S. et al. Localization and level of expression of $\beta$-catenin in human laryngeal squamous cell carcinoma. Otolaryngol Head Neck Surg, v.130, n.1, p.89-93, Jan. 2004.

49. LUNA, M.A. et al. Basaloid squamous carcinoma of the upper aerodigestive tractclinicopathologic and DNA flow cytometric analysis. Cancer, v.66, n.3, p.537-42, Aug. 1990.

50. MATHEWS, M.B. et al. Identity of the proliferating cell nuclear antigen and cyclin. Nature, v.309, n.5966, p.374-6, May 1984.

51. MATTIJSSEN, V. et al. E-cadherin expression in head and neck squamous cell carcinoma is associated with clinical outcome. Int J Cancer, v.55, n.4, p.580-5, Oct. 1993.

52. MCKAY, M.J.; BILOUS, A.M. Basaloid-squamous carcinoma of the hypopharynx. Cancer, v.63, n.12, p.2528-31, June 1989.

53. OZAWA, M.; BARIBAULT, H.; KEMLER, R. The cytoplasmic domain of the cell adhesion molecule uvomorulin associates with three independent proteins structurally related in different species. ЕMBO J, v.8, n.6, p.1711-7, June 1989.

54. PAULINO, A.F.G. et al. Basaloid squamous cell carcinoma of the head and neck. Laryngoscope, v.110, n.9, p.1479-82, Sept. 2000.

55. PINDBORG, J.J. et al. Histological typing of cancer and precancer of the oral mucosa. 2ed. Berlin, Springer, 1997. 87p.

56. PRELICH, G. et al. Functional identity of proliferating cell nuclear antigen and a DNA polymerase- $\delta$ auxiliary protein. Nature, v.326, n.6112, p.517-20, Apr. 1987.

57. RASLAN, W.S. et al. Basaloid squamous cell carcinoma of the head and neck: a clinicopathologic and flow cytometric study of 10 new cases with review of the English literature. Am. J. Otolaryngol, v.15, n.3, p.204-11, May/June 1994.

58. ROBBINS, B.A. et al. Immunohistochemical detection of proliferating cell nuclear antigen in solid human malignancies. Arch Pathol Lab Med, v.111, n.9, p.841-5, Sept. 1987.

59. SAKAKI, T. et al. Correlation of E- and P-cadherin expression with differentiation grade and mode of invasion in gingival carcinoma. Pathol Int, v.44, n.4, p.280-6, Apr. 1994. 
60. SARBIA, M. et al. Basaloid squamous cell carcinoma of the esophagus- diagnosis and prognosis. Cancer, v.79, n.9, p.1871-8, May 1997.

61. SARBIA, M. et al. Expression of Bcl-2 and amplification of $c-m y c$ are frequent in basaloid squamous cell carcinomas of the esophagus. Am J Pathol, v.155, n.4, p.1027-32, Oct. 1999.

62. SCHIPPER, J.H. et al. E-cadherin expression in squamous cell carcinomas of head and neck: inverse correlation with tumor dedifferentiation and lymph node metastasis. Cancer Res, v.51, n.23, p.6328-37, Dec. 1991.

63. SCHLIEPHAKE, H. Prognostic relevance of molecular markers of oral cancer- a review. Int J Oral Maxillofac Surg, v.32, n.3, p.233-45, June 2003.

64. SEIDMAN, J.F. et al. Basaloid squamous carcinoma of the hypopharynx and larynx associated with second primary tumors. Cancer, v.68, n.7, p.1545-9, Oct. 1991.

65. SETÄLÄ, L. et al. Clinical relevance of p53 index and expression of proliferating cell nuclear antigen and Ki-67 in gastric cancer. J Cancer Res Clin Oncol, v.124, n.9, p.497-502, 1998.

66. SHIMOYAMA, Y. et al. Cadherin cell-adhesion molecules in human epithelial tissues and carcinomas. Cancer Res, v. 49, n.8, p.2128-33, Apr. 1989.

67. SHINOHARA, M. et al. Immunohistochemical study of desmossomes in oral squamous cell carcinoma: correlation with cytokeratin and E-cadherin staining, and with tumour bahaviour. J Pathol, v.184, n.4, p.369-81, Apr. 1998.

68. SINGH, Z.N. et al. Basaloid-squamous carcinoma- a distinct histopathological entity, Indian J. Cancer, v.33, n.2, p.86-91, June 1996.

69. SITTEL, C. et al. Prognostic significance of KI-67 (MIB1), PCNA and p53 in cancer of the oropharynx and oral cavity. Oral Oncol, v.35, n.6, p.583-9, Nov. 1999.

70. SITTEL, C. et al. Ki-67 (MIB1), p53, and Lewis-X (LeuM1) as prognostic factors of recurrence in T1 and T2 laryngeal carcinoma. Laryngoscope, v.110, n.6, p.1012-7, June 2000.

71. SLAUS, N.P. Tumor suppressor gene E-cadherin and its role in normal and malignant cells. Cancer Cell Int, v.3, n.1, p.17-23, Oct. 2003.

72. SMITH, M.E.F.; PIGNATELLI, M. The molecular histology of neoplasia: the role of the cadherin/catenin complex. Histopathology, v.31, n.2, p.107-11, Aug. 1997. 
73. STATACORP.2001. Stata statistical software: release 7.0. College Station, Stata Corporation, 2001.

74. STOLL, C. et al. Prognostic significance of apoptosis and associated factors in oral squamous cell carcinoma. Virchows Arch, v.436, n.2, p.102-8, Feb. 2000.

75. TAKEICHI, M. Cadherin cell adhesion receptors as a morphogenetic regulator. Science, v.251, n.5000, p.1451-5, Mar. 1991.

76. TANAKA, N. et al. Expression of E-cadherin, $\alpha$-catenin, and $\beta$-catenin in the process of lymph node metastasis in oral squamous cell carcinoma. Br J Cancer, v.89, n.3, p.557-63, Aug. 2003.

77. TNM Classificação dos tumores malignos. Rio de Janeiro, Ministério da Saúde, Secretaria de Assistência à Saúde, Instituto Nacional do Câncer, 1998. p.19-55.

78. TSAI, S.T.; JIN, Y.T. Proliferating cell nuclear antigen (PCNA) expression in oral squamous cell carcinomas. J Oral Pathol Med, v.24, n.7, p.313-5, Aug. 1995.

79. TSUBOCHI, H. et al. Immunohistochemical study of basaloid squamous cell carcinoma, adenoid cystic and mucoepidermoid carcinoma in the upper aerodigestive tract. Anticancer Res, v.20, n.2B, p.1205-12, Mar./ Apr.2000.

80. TULUNAY, Ö et al. Basaloid squamous cell carcinoma of the maxilla: a case report and immunohistochemical analysis, Acta Otolaryngol, v.122, n.4, p.424-8, June 2002.

81. VICENTE, J.C. et al. Expression of cyclin D1 and Ki-67 in squamous cell carcinoma of the oral cavity: clinicopathological and prognostic significance. Oral Oncol, v.38, n.3, p.301-8, Apr.2002.

82. WAIN, S.L. et al. Basaloid-squamous cell carcinoma of the tongue, hipopharynx, and larynx: report of 10 cases. Human Pathol, v.17, n.11, p.1158-66, Nov.1986.

83. WALSH, L.J. et al. The role of adhesion molecules in oral cancer. Aust Dent J, v.41, n.2, p.80-2, Apr. 1996.

84. WARNAKULASURIYA, K.A.A.S.; JOHNSON, N.W. Importance of proliferation markers in oral pathology. Currents Topics Pathol, v.90, p.147-77, 1996.

85. WEDENBERG, C. et al. Basaloid squamous cell carcinoma of the maxilla. Oral Oncol, v.33, n.2, p.141-4, Mar. 1997.

86. WHEELOCK, M.J.; JOHNSON, K.R. Cadherins as modulators of cellular phenotype. Annu Rev Cell Dev Biol, v.19, p.207-35, 2003. 
87. WIENEKE, J.A.; THOMPSON, L.D.R.; WENIG, B.M. Basaloid squamous cell carcinoma of the sinonasal tract. Cancer, v.85, n.4, p.841-54, Feb. 1999.

88. WIJNHOVEN, B.P.L.; DINJENS, W.N.M., PIGNATELLI, M. E-cadherin-catenin cellcell adhesion complex and human cancer. Br J Surg, v.87, n.8, p. 992-1005, Aug. 2000.

89. WILLIAMS, H.K. et al. Expression of cadherins and catenins in oral epithelial dysplasia and squamous cell carcinoma. J Oral Pathol Med, v.27, n.7, p.308-17, Aug. 1998.

90. WINZENBURG, S.M. et al. Basaloid squamous carcinoma: a clinical comparison of two histologic types with poorly differentiated squamous cell carcinoma. Otolaryngol Head Neck Surg, v.119, n.5, p.471-5, Nov. 1998.

91. XIE, X. et al. Prognostic significance of proliferative and apoptotic markers in oral tongue squamous cell carcinomas. Oral Oncol, v.35, n.5, p.502-9, Sept. 1999.

92. YAMADA, K. et al. The relationship between E-cadherin expression, clinical stage and tumour differentiation in oral squamous cell carcinoma. Oral Dis, v.3, n.2, p.82-5, June 1997.

93. YOSHIDA-NORO, C.; SUZUKI, N.; TAKEICHI, M. Molecular nature of the calciumdependent cell-cell adhesion system im mouse teratocarcinoma and embryonic cells studied with a monoclonal antibody. Dev Biol, v.101, n.1, p.19-27, Jan. 1984.

94. ZHAO, X.J. et al. Expression of e-cadherin and $\beta$-catenin in human esophageal squamous cell carcinoma: relationships with prognosis. World J Gastroenterol, v.9, n.2, p.22532, Feb. 2003. 
ABSTRACT 


\section{EXPRESSION OF PCNA, E-CADHERIN, AND $\beta$-CATENIN IN ORAL SQUAMOUS \\ CELL AND BASALOID SQUAMOUS CARCINOMAS: CORRELATION WITH CLINICAL BEHAVIOUR AND PROGNOSES}

Basaloid squamous carcinoma (BSC), a distinct aggressive variant of squamous cell carcinoma (SCC), presents preference for head and neck region, specially base of tongue. Seventeen cases of BSC localized exclusively in mouth, diagnosed and treated from 1970 to 2000 at Department of Head and Neck Surgery and Otorhinolaryngology of Cancer Hospital AC Camargo, were compared to 26 cases of poorly differentiated SCC (PDSCC) and 28 cases of well to moderately differentiated SCC (W/MSCC) matched by stage and tumor site. It was evaluated some characteristics like gender, race, tobacco, alcohol abuse, localization of primary tumor, stage by TNM system, treatment, occurrence of local and cervical recurrence, regional lymph node and distant metastasis and second primary tumors. In addition, others biological features such as PCNA, E-cadherin and $\beta$-catenin expression in BSC, PDSCC and W/MSCC were evaluated in relation to their clinicopathological features and prognostic values using Kaplan-Meier method and Cox regression models. No statistically significant differences were found among all three groups in regard to clinical features and immunohistochemical reactivity for PCNA. For groups PDSCC and BSC, reduction or absence of E-cadherin staining was observed in more than $80.0 \%$ of carcinomas and it was statistically significant when compared to W/MSCC $(\mathrm{p}=0.019)$. A strong expression of $\beta$ catenin was observed, respectively, in $26.9 \%$ and $20.8 \%$ of W/MSCC and PDSCC, and in $41.2 \%$ of BSC. The 5-year and 10-year overall and disease-free survival rates demonstrated no significant differences among BSCC, PDSCC and W/MSCC groups and the PCNA, Ecadherin and $\beta$-catenin also showed no prognostic value. Metastasis in regional lymph node $(\mathrm{N}+)$ was an independent prognosis factor for the oral BSC, PDSCC and W/MSCC patients. These results suggest that the clinical and biological behaviour of BSC, PDSCC and W/MSCC of the oral cavity are similar when matched by clinical stage and tumor site. The histological grade in squamous cell carcinoma or the microscopic tumor variant (BSC or $\mathrm{SCC}$ ) is not a determinant parameter to predict the prognoses when these tumors present advanced clinical stage. 
APÊTIDICE 
APÊNDICE 1 - Distribuição do PCNA em relação às características clínicas e microscópicas dos carcinomas escamosos basalóides de boca. Hospital do Câncer, São Paulo, 1970 a 2000

\begin{tabular}{|c|c|c|c|c|c|}
\hline \multirow{3}{*}{ Variável } & \multicolumn{4}{|c|}{ GRUPO CEB } & \multirow{3}{*}{$p^{*}$} \\
\hline & \multicolumn{2}{|c|}{ PCNA $\leq 61$} & \multicolumn{2}{|c|}{ PCNA $>61$} & \\
\hline & $\mathbf{N}$ & $\%$ & $\mathbf{N}$ & $\%$ & \\
\hline \multicolumn{6}{|l|}{ Estadiamento T } \\
\hline $\mathrm{T} 1-2$ & 2 & 40,0 & 2 & 20,0 & \multirow{2}{*}{0,560} \\
\hline $\mathrm{T} 3-4$ & 3 & 60,0 & 8 & 80,0 & \\
\hline \multicolumn{6}{|l|}{ Estadiamento $\mathbf{N}$} \\
\hline N0 & 1 & 20,0 & 2 & 20,0 & \multirow{2}{*}{ NA } \\
\hline N1 & 4 & 80,0 & 8 & 80,0 & \\
\hline \multicolumn{6}{|l|}{ Localização } \\
\hline Língua & 1 & 20,0 & 2 & 20,0 & \multirow{3}{*}{ NA } \\
\hline Soalho & 3 & 60,0 & 5 & 50,0 & \\
\hline Retromolar/Gengiva & 1 & 20,0 & 3 & 30,0 & \\
\hline \multicolumn{6}{|l|}{ Tipo de lesão } \\
\hline Ulcerovegetante & 1 & 20,0 & 5 & 50,0 & \multirow{2}{*}{0,580} \\
\hline Ulceroinfiltrativa & 4 & 80,0 & 5 & 50,0 & \\
\hline \multicolumn{6}{|l|}{ Recidiva local } \\
\hline Não & 4 & 80,0 & 9 & 90,0 & \multirow{2}{*}{ NA } \\
\hline Sim & 1 & 20,0 & 1 & 10,0 & \\
\hline \multicolumn{6}{|l|}{ Recidiva regional } \\
\hline Não & 2 & 40,0 & 8 & 80,0 & \multirow{2}{*}{0,251} \\
\hline Sim & 3 & 60,0 & 2 & 20,0 & \\
\hline \multicolumn{6}{|l|}{ Metástase } \\
\hline Não & 3 & 60,0 & 8 & 80,0 & \multirow{2}{*}{0,560} \\
\hline Sim & 2 & 40,0 & 2 & 20,0 & \\
\hline \multicolumn{6}{|l|}{ Embolização vascular } \\
\hline Ausente & 3 & 60,0 & 7 & 70,0 & \multirow{2}{*}{0,999} \\
\hline Presente & 2 & 40,0 & 3 & 30,0 & \\
\hline \multicolumn{6}{|l|}{ Infiltração perineural } \\
\hline Ausente & 4 & 80,0 & 8 & 80,0 & \multirow{2}{*}{0,999} \\
\hline Presente & 1 & 20,0 & 2 & 20,0 & \\
\hline \multicolumn{6}{|l|}{ Infiltração muscular } \\
\hline Ausente & 0 & 0,0 & 4 & 40,0 & \multirow[t]{2}{*}{0,231} \\
\hline Presente & 5 & 100,0 & 6 & 60,0 & \\
\hline \multicolumn{6}{|l|}{ Infiltração óssea } \\
\hline Ausente & 0 & 0,0 & 6 & 75,0 & \multirow{2}{*}{ NA } \\
\hline Presente & 2 & 100,0 & 2 & 25,0 & \\
\hline TOTAL & 5 & 100,0 & 10 & 100,0 & \\
\hline
\end{tabular}

$p^{*}$ : valor obtido pelo teste exato de Fisher considerando-se nível de significância de 5\%

NA: não se aplica 
APÊNDICE 2 - Distribuição do PCNA em relação às características clínicas dos carcinomas espinocelulares de boca. Hospital do Câncer, São Paulo, 1970 a 2000

\begin{tabular}{|c|c|c|c|c|c|c|c|c|c|c|}
\hline \multirow{4}{*}{ Variável } & \multicolumn{9}{|c|}{ GRUPOS } & \multirow[b]{4}{*}{$p^{*}$} \\
\hline & \multicolumn{4}{|c|}{ CEC/PD } & \multicolumn{5}{|c|}{ CEC/BD } & \\
\hline & \multicolumn{2}{|c|}{$\mathrm{PCNA} \leq 61$} & \multicolumn{2}{|c|}{ PCNA $>61$} & \multirow[b]{2}{*}{$p^{*}$} & \multicolumn{2}{|c|}{ PCNA $\leq 61$} & \multicolumn{2}{|c|}{ PCNA $>61$} & \\
\hline & $\mathbf{N}$ & $\%$ & $\mathbf{N}$ & $\%$ & & $\mathbf{N}$ & $\%$ & $\mathbf{N}$ & $\%$ & \\
\hline \multicolumn{11}{|l|}{ Estadiamento $\mathbf{T}$} \\
\hline $\mathrm{T} 1-2$ & 3 & 20,0 & 3 & 27,3 & \multirow{2}{*}{0,999} & 4 & 25,0 & 5 & 41,7 & \multirow{2}{*}{0,432} \\
\hline T3-4 & 12 & 80,0 & 8 & 72,7 & & 12 & 75,0 & 7 & 58,3 & \\
\hline \multicolumn{11}{|l|}{ Estadiamento $\mathbf{N}$} \\
\hline No & 5 & 33,3 & 3 & 27,3 & \multirow{2}{*}{0,999} & 4 & 25,0 & 5 & 41,7 & \multirow{2}{*}{0,432} \\
\hline N1 & 10 & 66,7 & 8 & 72,7 & & 12 & 75,0 & 7 & 58,3 & \\
\hline \multicolumn{11}{|l|}{ Localização } \\
\hline Língua & 3 & 20,0 & 2 & 18,2 & \multirow{3}{*}{ NA } & 3 & 18,7 & 4 & 33,3 & \multirow{3}{*}{ NA } \\
\hline Soalho & 3 & 20,0 & 6 & 54,5 & & 6 & 37,5 & 2 & 16,7 & \\
\hline Retromolar/gengiva & 9 & 60,0 & 3 & 27,3 & & 7 & 43,8 & 6 & 50,0 & \\
\hline \multicolumn{11}{|l|}{ Tipo de lesão } \\
\hline Ulcerovegetante & 5 & 33,3 & 3 & 27,3 & \multirow{2}{*}{0,999} & 3 & 18,7 & 0 & 0,0 & \multirow{2}{*}{0,238} \\
\hline Ulceroinfiltrativa & 10 & 66,7 & 8 & 72,7 & & 13 & 81,3 & 12 & 100,0 & \\
\hline \multicolumn{11}{|l|}{ Recidiva local } \\
\hline Não & 9 & 60,0 & 7 & 63,6 & \multirow{2}{*}{0,999} & 13 & 81,3 & 9 & 75,0 & \multirow{2}{*}{0,999} \\
\hline Sim & 6 & 40,0 & 4 & 36,4 & & 3 & 18,7 & 3 & 25,0 & \\
\hline \multicolumn{11}{|l|}{ Recidiva regional } \\
\hline Não & 11 & 73,3 & 10 & 90,9 & \multirow{2}{*}{0,356} & 13 & 81,3 & 7 & 58,3 & \multirow{2}{*}{0,231} \\
\hline Sim & 4 & 26,7 & 1 & 9,1 & & 3 & 18,7 & 5 & 41,7 & \\
\hline \multicolumn{11}{|l|}{ Metástase } \\
\hline Não & 13 & 86,7 & 9 & 81,8 & \multirow{2}{*}{0,999} & 16 & 100,0 & 12 & 100,0 & NA \\
\hline Sim & 2 & 13,3 & 2 & 19,2 & & 0 & 0,0 & 0 & 0,0 & \\
\hline TOTAL & 15 & 100,0 & 11 & 100,0 & & 16 & 100,0 & 12 & 100,0 & \\
\hline
\end{tabular}

$p^{*}=$ valor obtido pelo teste exato de Fisher considerando-se nível de significância de 5\% NA: não se aplica 
APÊNDICE 3 - Distribuição do PCNA em relação às características microscópicas dos carcinomas espinocelulares de boca. Hospital do Câncer, São Paulo, 1970 a 2000

\begin{tabular}{|c|c|c|c|c|c|c|c|c|c|c|}
\hline \multirow{4}{*}{ Variável } & \multicolumn{9}{|c|}{ GRUPOS } & \multirow[b]{4}{*}{$p^{*}$} \\
\hline & \multicolumn{4}{|c|}{ CEC/PD } & \multicolumn{5}{|c|}{ CEC/BD } & \\
\hline & \multicolumn{2}{|c|}{$\mathrm{PCNA} \leq 61$} & \multicolumn{2}{|c|}{ PCNA > 61} & \multirow[b]{2}{*}{$p^{*}$} & \multicolumn{2}{|c|}{ PCNA $\leq 61$} & \multicolumn{2}{|c|}{ PCNA $>61$} & \\
\hline & $\mathbf{N}$ & $\%$ & $\mathbf{N}$ & $\%$ & & $\mathbf{N}$ & $\%$ & $\mathbf{N}$ & $\%$ & \\
\hline \multicolumn{11}{|l|}{ Queratinização } \\
\hline Alta & 3 & 20,0 & 0 & 0,0 & \multirow{2}{*}{ NA } & 15 & 93,7 & 12 & 100,0 & \multirow{2}{*}{$\mathrm{NA}$} \\
\hline Baixa & 12 & 80,0 & 11 & 100,0 & & 1 & 6,3 & 0 & 0,0 & \\
\hline \multicolumn{11}{|c|}{ Pleomorfismo nuclear } \\
\hline Baixo & 8 & 53,3 & 7 & 63,6 & \multirow{2}{*}{0,701} & 16 & 100,0 & 11 & 91,7 & \multirow{2}{*}{ NA } \\
\hline Alto & 7 & 46,7 & 4 & 36,4 & & 0 & 0,0 & 1 & 8,3 & \\
\hline \multicolumn{11}{|l|}{ Número de mitoses } \\
\hline Baixo & 10 & 66,7 & 4 & 36,4 & \multirow{2}{*}{0,126} & 16 & 100,0 & 11 & 91,7 & \multirow{2}{*}{ NA } \\
\hline Alto & 5 & 33,3 & 7 & 63,6 & & 0 & 0,0 & 1 & 8,3 & \\
\hline \multicolumn{11}{|l|}{ Padrão de invasão } \\
\hline Compressivo & 1 & 6,7 & 3 & 27,3 & \multirow{2}{*}{0,279} & 1 & 6,3 & 4 & 33,3 & \multirow{2}{*}{0,133} \\
\hline Infiltrativo & 14 & 93,3 & 8 & 72,7 & & 15 & 93,7 & 8 & 66,7 & \\
\hline \multicolumn{11}{|c|}{ Infiltrado inflamatório } \\
\hline Intenso & 12 & 80,0 & 7 & 63,6 & \multirow{2}{*}{0,407} & 13 & 81,3 & 10 & 83,3 & \multirow{2}{*}{0,999} \\
\hline Discreto & 3 & 20,0 & 4 & 36,4 & & 3 & 18,7 & 2 & 16,7 & \\
\hline \multicolumn{11}{|c|}{ Índice de malignidade } \\
\hline Pouco agressivo & 0 & 0,0 & 0 & 0,0 & NA & 12 & 75,0 & 9 & 75,0 & 0,999 \\
\hline Muito agressivo & 15 & 100,0 & 11 & 100,0 & & 4 & 25,0 & 3 & 25,0 & \\
\hline Embolização vasc & & & & & & & & & & \\
\hline Ausente & 12 & 80,0 & 7 & 63,6 & 0,407 & 8 & 50,0 & 8 & 66,7 & 0,378 \\
\hline Presente & 3 & 20,0 & 4 & 36,4 & $0,+01$ & 8 & 50,0 & 4 & 33,3 & סו ד, \\
\hline Infiltração perin & & & & & & & & & & \\
\hline Ausente & 4 & 26,7 & 4 & 36,4 & 0,683 & 8 & 50,0 & 5 & 41,7 & 0,662 \\
\hline Presente & 11 & 73,3 & 7 & 63,6 & , & 8 & 50,0 & 7 & 58,3 & 0,002 \\
\hline Infiltração mus & & & & & & & & & & \\
\hline Ausente & 2 & 13,3 & 5 & 45,5 & 0,095 & 5 & 31,3 & 2 & 16,7 & 0,662 \\
\hline Presente & 13 & 86,7 & 6 & 54,5 & נינס, & 11 & 68,7 & 10 & 83,3 & 0,00 \\
\hline Infiltração óssea* & & & & & & & & & & \\
\hline Ausente & 5 & 45,5 & 2 & 50,0 & 0,999 & 6 & 60,0 & 5 & 71,4 & 0,999 \\
\hline Presente & 6 & 54,5 & 2 & 50,0 & & 4 & 40,0 & 2 & 28,6 & נונים \\
\hline TOTAL & 15 & 100,0 & 11 & 100,0 & & 16 & 100,0 & 12 & 100,0 & \\
\hline
\end{tabular}

$p^{*}$ : valor obtido pelo teste exato de Fisher considerando-se nível de significância de 5\%

**: excluídos os pacientes com informações ignoradas

NA: não se aplica 
APÊNDICE 4 - Distribuição de E-caderina e $\beta$-catenina em relação às características clínicas e microscópicas dos carcinomas escamosos basalóides de boca. Hospital do Câncer, São Paulo, 1970 a 2000

\begin{tabular}{|c|c|c|c|c|c|c|c|c|c|c|}
\hline \multirow{4}{*}{ Variável } & \multicolumn{9}{|c|}{ GRUPO CEB } & \multirow[b]{4}{*}{$p^{*}$} \\
\hline & \multicolumn{4}{|c|}{ E-caderina } & \multicolumn{5}{|c|}{$\beta$-catenina } & \\
\hline & \multicolumn{2}{|c|}{ Fraca } & \multicolumn{2}{|c|}{ Forte } & \multirow[b]{2}{*}{$p^{*}$} & \multicolumn{2}{|c|}{ Fraca } & \multicolumn{2}{|c|}{ Forte } & \\
\hline & $\mathbf{N}$ & $\%$ & $\mathbf{N}$ & $\%$ & & $\mathbf{N}$ & $\%$ & $\mathbf{N}$ & $\%$ & \\
\hline \multicolumn{11}{|l|}{ Estadiamento $T$} \\
\hline $\mathrm{T} 1-2$ & 3 & 20,0 & 2 & 100,0 & \multirow{2}{*}{ NA } & 2 & 20,0 & 3 & 42,9 & \multirow{2}{*}{0,593} \\
\hline T3-4 & 12 & 80,0 & 0 & 0,0 & & 8 & 80,0 & 4 & 57,1 & \\
\hline \multicolumn{11}{|l|}{ Estadiamento N } \\
\hline No & 3 & 20,0 & 2 & 100,0 & \multirow{2}{*}{ NA } & 2 & 20,0 & 3 & 42,9 & \multirow{2}{*}{0,593} \\
\hline N1 & 12 & 80,0 & 0 & 0,0 & & 8 & 80,0 & 4 & 57,1 & \\
\hline \multicolumn{11}{|l|}{ Localização } \\
\hline Língua & 3 & 20,0 & 0 & 0,0 & \multirow{3}{*}{ NA } & 2 & 20,0 & 1 & 14,3 & \multirow{3}{*}{ NA } \\
\hline Soalho & 8 & 53,3 & 2 & 100,0 & & 5 & 50,0 & 5 & 71,4 & \\
\hline Retromolar/gengiva & 4 & 26,7 & 0 & 0,0 & & 3 & 30,0 & 1 & 14,3 & \\
\hline \multicolumn{11}{|l|}{ Tipo de lesão } \\
\hline Ulcerovegetante & 7 & 46,7 & 0 & 0,0 & \multirow{2}{*}{ NA } & 3 & 30,0 & 4 & 57,1 & \multirow{2}{*}{0,350} \\
\hline Ulceroinfiltrativa & 8 & 53,3 & 2 & 100,0 & & 7 & 70,0 & 3 & 42,9 & \\
\hline \multicolumn{11}{|l|}{ Recidiva local } \\
\hline Não & 12 & 80,0 & 2 & 100,0 & \multirow{2}{*}{ NA } & 8 & 80,0 & 6 & 85,7 & 0,999 \\
\hline Sim & 3 & 20,0 & 0 & 0,0 & & 2 & 20,0 & 1 & 14,3 & צ'ו \\
\hline Recidiva regional & & & & & & & & & & \\
\hline Não & 10 & 66,7 & 2 & 100,0 & NA & 7 & 70,0 & 5 & 71,4 & 0,999 \\
\hline Sim & 5 & 33,3 & 0 & 0,0 & 101 & 3 & 30,0 & 2 & 28,6 & נרנטס \\
\hline Metástase & & & & & & & & & & \\
\hline Não & 11 & 73,3 & 2 & 100,0 & NA & 7 & 70,0 & 6 & 85,7 & 0.603 \\
\hline Sim & 4 & 26,7 & 0 & 0,0 & & 3 & 30,0 & 1 & 14,3 & \\
\hline Embolização vascula & & & & & & & & & & \\
\hline Ausente & 10 & 66,7 & 2 & 100,0 & NA & 7 & 70,0 & 5 & 71,4 & 0,999 \\
\hline Presente & 5 & 33,3 & 0 & 0,0 & & 3 & 30,0 & 2 & 28,6 & \\
\hline Infiltração perineura & & & & & & & & & & \\
\hline Ausente & 12 & 80,0 & 2 & 100,0 & NA & 8 & 80,0 & 6 & 85,7 & 0,999 \\
\hline Presente & 3 & 20,0 & 0 & 0,0 & & 2 & 20,0 & 1 & 14,3 & \\
\hline Infiltração muscular & & & & & & & & & & \\
\hline Ausente & 4 & 26,7 & 1 & 50,0 & NA & 0 & 0,0 & 5 & 29,4 & 0,003 \\
\hline Presente & 11 & 73,3 & 1 & 50,0 & $1 \mathrm{~A}$ & 10 & 100,0 & 2 & 70,6 & $0,00 \mathrm{~J}$ \\
\hline Infiltração óssea** & & & & & & & & & & \\
\hline Ausente & 6 & 60,0 & 1 & 100,0 & NA & 3 & 50,0 & 4 & 80,0 & 0,545 \\
\hline Presente & 4 & 40,0 & 0 & 0,0 & 101 & 3 & 50,0 & 1 & 20,0 & נד, \\
\hline TOTAL & 15 & 100,0 & 2 & 100,0 & & 10 & 100,0 & 7 & 100,0 & \\
\hline
\end{tabular}

$p^{*}$ : valor obtido pelo teste exato de Fisher considerando-se nível de significância de 5\%

**: excluídos os pacientes com informações ignoradas

NA: não se aplica 
APÊNDICE 5 - Distribuição de E-caderina e $\beta$-catenina em relação às características clínicas dos carcinomas espinocelulares pouco diferenciados de boca. Hospital do Câncer, São Paulo, 1970 a 2000

\begin{tabular}{|c|c|c|c|c|c|c|c|c|c|c|}
\hline \multirow{4}{*}{ Variável } & \multicolumn{9}{|c|}{ GRUPO CEC/PD } & \multirow[b]{4}{*}{$p^{*}$} \\
\hline & \multicolumn{4}{|c|}{ E-caderina } & \multicolumn{5}{|c|}{$\beta$-catenina } & \\
\hline & \multicolumn{2}{|c|}{ Fraca } & \multicolumn{2}{|c|}{ Forte } & \multirow[b]{2}{*}{$p^{*}$} & \multicolumn{2}{|c|}{ Fraca } & \multicolumn{2}{|c|}{ Forte } & \\
\hline & $\mathbf{N}$ & $\%$ & $\mathbf{N}$ & $\%$ & & $\mathbf{N}$ & $\%$ & $\mathbf{N}$ & $\%$ & \\
\hline \multicolumn{11}{|l|}{ Estadiamento T } \\
\hline T1-2 & 6 & 28,6 & 0 & 0,0 & \multirow{2}{*}{0,298} & 4 & 21,0 & 2 & 40,0 & \multirow{2}{*}{0,568} \\
\hline T3-4 & 15 & 71,4 & 5 & 100,0 & & 15 & 79,0 & 3 & 60,0 & \\
\hline \multicolumn{11}{|l|}{ Estadiamento $\mathbf{N}$} \\
\hline N0 & 8 & 38,1 & 0 & 0,0 & \multirow{2}{*}{0,150} & 7 & 36,8 & 1 & 20,0 & \multirow{2}{*}{0,631} \\
\hline N1 & 13 & 61,9 & 5 & 100,0 & & 12 & 63,2 & 4 & 80,0 & \\
\hline \multicolumn{11}{|l|}{ Localização } \\
\hline Língua & 5 & 23,8 & 0 & 0,0 & \multirow{3}{*}{ NA } & 4 & 21,0 & 0 & 0,0 & \multirow{3}{*}{ NA } \\
\hline Soalho & 8 & 38,1 & 1 & 20,0 & & 6 & 31,6 & 2 & 40,0 & \\
\hline Retromolar/gengiva & 8 & 38,1 & 4 & 80,0 & & 9 & 47,4 & 3 & 60,0 & \\
\hline \multicolumn{11}{|l|}{ Tipo de lesão } \\
\hline Ulcerovegetante & 4 & 19,0 & 4 & 80,0 & \multirow{2}{*}{$\mathbf{0 , 0 2 0}$} & 6 & 31,6 & 2 & 40,0 & \multirow{2}{*}{0,999} \\
\hline Ulceroinfiltrativa & 17 & 81,0 & 1 & 20,0 & & 13 & 68,4 & 3 & 60,0 & \\
\hline \multicolumn{11}{|l|}{ Recidiva local } \\
\hline Não & 12 & 57,1 & 4 & 80,0 & \multirow{2}{*}{0,617} & 12 & 63,2 & 4 & 80,0 & \multirow{2}{*}{0,631} \\
\hline Sim & 9 & 42,9 & 1 & 20,0 & & 7 & 36,8 & 1 & 20,0 & \\
\hline \multicolumn{11}{|l|}{ Recidiva regional } \\
\hline Não & 16 & 76,2 & 5 & 100,0 & \multirow{2}{*}{0,545} & 16 & 84,2 & 4 & 80,0 & \multirow{2}{*}{0,999} \\
\hline Sim & 5 & 23,8 & 0 & 0,0 & & 3 & 15,8 & 1 & 20,0 & \\
\hline \multicolumn{11}{|l|}{ Metástase } \\
\hline Não & 17 & 81,0 & 5 & 100,0 & \multirow{2}{*}{0,555} & 15 & 78,9 & 5 & 100,0 & 0544 \\
\hline Sim & 4 & 19,0 & 0 & 0,0 & & 4 & 21,1 & 0 & 0,0 & \\
\hline TOTAL & 21 & 100,0 & 5 & 100,0 & & 19 & 100,0 & 5 & 100,0 & \\
\hline
\end{tabular}

$p^{*}$ : valor obtido pelo teste exato de Fisher considerando-se nível de significância de 5\% NA: não se aplica 
APÊNDICE 6 - Distribuição de E-caderina e $\beta$-catenina em relação às características microscópicas dos carcinomas espinocelulares pouco diferenciados de boca. Hospital do Câncer, São Paulo, 1970 a 2000

\begin{tabular}{|c|c|c|c|c|c|c|c|c|c|c|}
\hline \multirow{4}{*}{ Variável } & \multicolumn{9}{|c|}{ GRUPO CEC/PD } & \multirow[b]{4}{*}{$p^{*}$} \\
\hline & \multicolumn{4}{|c|}{ E-caderina } & \multicolumn{5}{|c|}{$\beta$-catenina } & \\
\hline & \multicolumn{2}{|c|}{ Fraca } & \multicolumn{2}{|c|}{ Forte } & \multirow[b]{2}{*}{$p^{*}$} & \multicolumn{2}{|c|}{ Fraca } & \multicolumn{2}{|c|}{ Forte } & \\
\hline & $\mathbf{N}$ & $\%$ & $\mathbf{N}$ & $\%$ & & $\mathbf{N}$ & $\%$ & $\mathbf{N}$ & $\%$ & \\
\hline \multicolumn{11}{|l|}{ Queratinização } \\
\hline Alta & 1 & 4,8 & 2 & 40,0 & \multirow{2}{*}{0,085} & 2 & 10,5 & 1 & 20,0 & \multirow{2}{*}{0,521} \\
\hline Baixa & 20 & 95,2 & 3 & 60,0 & & 17 & 89,5 & 4 & 80,0 & \\
\hline \multicolumn{11}{|c|}{ Pleomorfismo nuclear } \\
\hline Baixo & 11 & 52,4 & 4 & 80,0 & \multirow{2}{*}{0,356} & 9 & 47,4 & 4 & 80,0 & \multirow{2}{*}{0,327} \\
\hline Alto & 10 & 47,6 & 1 & 20,0 & & 10 & 52,6 & 1 & 20,0 & \\
\hline \multicolumn{11}{|c|}{ Número de mitoses } \\
\hline \multirow{2}{*}{$\begin{array}{l}\text { Baixo } \\
\text { Alto }\end{array}$} & 10 & 47,6 & 4 & 80,0 & \multirow{2}{*}{0,330} & \multirow{2}{*}{$\begin{array}{c}10 \\
9\end{array}$} & \multirow{2}{*}{$\begin{array}{l}52,6 \\
47,4\end{array}$} & \multirow{2}{*}{$\begin{array}{l}3 \\
2\end{array}$} & \multirow{2}{*}{$\begin{array}{l}60,0 \\
40,0\end{array}$} & \multirow[t]{2}{*}{0,999} \\
\hline & 11 & 52,4 & 1 & 20,0 & & & & & & \\
\hline \multicolumn{11}{|l|}{ Padrão de invasão } \\
\hline Compressivo & 4 & 19,0 & 0 & 0,0 & \multirow{2}{*}{0,555} & 3 & 15,8 & 1 & 20,0 & 0.999 \\
\hline Infiltrativo & 17 & 81,0 & 5 & 100,0 & & 16 & 84,2 & 4 & 80,0 & \\
\hline Infiltrado inflam: & & & & & & & & & & \\
\hline Intenso & 15 & 71,4 & 4 & 80,0 & 0,999 & 15 & 78,9 & 3 & 60,0 & 0,568 \\
\hline Discreto & 6 & 28,6 & 1 & 20,0 & & 4 & 21,1 & 2 & 40,0 & \\
\hline Índice de maligni & & & & & & & & & & \\
\hline Pouco agressivo & 0 & 0,0 & 0 & 0,0 & NA & 0 & 0,0 & 0 & 0,0 & NA \\
\hline Muito agressivo & 21 & 100,0 & 5 & 100,0 & NA & 19 & 100,0 & 5 & 100,0 & \\
\hline Embolização vasc & & & & & & & & & & \\
\hline Ausente & 15 & 71,4 & 4 & 80,0 & 0,999 & 15 & 78,9 & 3 & 60,0 & 0.568 \\
\hline Presente & 6 & 28,6 & 1 & 20,0 & 0,999 & 4 & 21,1 & 2 & 40,0 & 0,500 \\
\hline Infiltração peri & & & & & & & & & & \\
\hline Ausente & 7 & 33,3 & 1 & 20,0 & 0,999 & 5 & 26,3 & 3 & 60,0 & 0,289 \\
\hline Presente & 14 & 66,7 & 4 & 80,0 & ס, & 14 & 73,7 & 2 & 40,0 & 0,209 \\
\hline Infiltração musc & & & & & & & & & & \\
\hline Ausente & 6 & 28,6 & 1 & 20,0 & 0,999 & 5 & 26,3 & 2 & 40,0 & 0,608 \\
\hline Presente & 15 & 71,4 & 4 & 80,0 & & 14 & 73,7 & 3 & 60,0 & \\
\hline Infiltração óssea* & & & & & & & & & & \\
\hline Ausente & 4 & 36,4 & 3 & 75,0 & 0,282 & 4 & 33,3 & 2 & 100,0 & NA \\
\hline Presente & 7 & 63,6 & 1 & 25,0 & 0,202 & 8 & 66,7 & 0 & 0,0 & IVA \\
\hline TOTAL & 21 & 100,0 & 5 & 100,0 & & 19 & 100,0 & 5 & 100,0 & \\
\hline
\end{tabular}

$p^{*}$ : valor obtido pelo teste exato de Fisher considerando-se nível de significância de 5\%

**: excluídos os pacientes com informações ignoradas 
APÊNDICE 7 - Distribuição de E-caderina e $\beta$-catenina em relação às características clínicas dos carcinomas espinocelulares bem diferenciados de boca. Hospital do Câncer, São Paulo, 1970 a 2000

\begin{tabular}{|c|c|c|c|c|c|c|c|c|c|c|}
\hline \multirow{4}{*}{ Variável } & \multicolumn{9}{|c|}{ GRUPO CEC/BD } & \multirow[b]{4}{*}{$p^{*}$} \\
\hline & \multicolumn{4}{|c|}{ E-caderina } & \multicolumn{5}{|c|}{$\beta$-catenina } & \\
\hline & \multicolumn{2}{|c|}{ Fraca } & \multicolumn{2}{|c|}{ Forte } & \multirow[b]{2}{*}{$p^{*}$} & \multicolumn{2}{|c|}{ Fraca } & \multicolumn{2}{|c|}{ Forte } & \\
\hline & $\mathbf{N}$ & $\%$ & $\mathbf{N}$ & $\%$ & & $\mathbf{N}$ & $\%$ & $\mathbf{N}$ & $\%$ & \\
\hline \multicolumn{11}{|l|}{ Estadiamento $\mathbf{T}$} \\
\hline $\mathrm{T} 1-2$ & 5 & 33,3 & 4 & 30,8 & \multirow{2}{*}{0,999} & 5 & 26,3 & 2 & 28,6 & \multirow{2}{*}{0,999} \\
\hline T3-4 & 10 & 66,7 & 9 & 69,2 & & 14 & 73,7 & 5 & 71,4 & \\
\hline \multicolumn{11}{|l|}{ Estadiamento N } \\
\hline No & 4 & 26,7 & 5 & 38,5 & \multirow{2}{*}{0,689} & 5 & 26,3 & 4 & 57,1 & \multirow{2}{*}{0,188} \\
\hline N1 & 11 & 73,3 & 8 & 61,5 & & 14 & 73,7 & 3 & 42,9 & \\
\hline \multicolumn{11}{|l|}{ Localização } \\
\hline Língua & 3 & 20,0 & 4 & 30,8 & \multirow{3}{*}{ NA } & 6 & 31,6 & 0 & 0,0 & \multirow{3}{*}{ NA } \\
\hline Soalho & 5 & 33,3 & 3 & 23,1 & & 5 & 26,3 & 3 & 42,9 & \\
\hline Retromolar/gengiva & 7 & 46,7 & 6 & 46,1 & & 8 & 42,1 & 4 & 57,1 & \\
\hline \multicolumn{11}{|l|}{ Tipo de lesão } \\
\hline Ulcerovegetante & 1 & 6,7 & 2 & 15,4 & \multirow{2}{*}{0,583} & 3 & 15,8 & 0 & 0,0 & \multirow{2}{*}{ NA } \\
\hline Ulceroinfiltrativa & 14 & 93,3 & 11 & 84,6 & & 16 & 84,2 & 7 & 100,0 & \\
\hline \multicolumn{11}{|l|}{ Recidiva local } \\
\hline Não & 12 & 80,0 & 10 & 76,9 & \multirow{2}{*}{0,999} & 15 & 78,9 & 5 & 71,4 & \multirow{2}{*}{0,999} \\
\hline Sim & 3 & 20,0 & 3 & 23,1 & & 4 & 21,1 & 2 & 28,6 & \\
\hline \multicolumn{11}{|l|}{ Recidiva regional } \\
\hline Não & 13 & 86,7 & 7 & 53,9 & \multirow{2}{*}{0,096} & 14 & 73,7 & 5 & 71,4 & \multirow{2}{*}{0,999} \\
\hline Sim & 2 & 13,3 & 6 & 46,1 & & 5 & 26,3 & 2 & 28,6 & \\
\hline \multicolumn{11}{|l|}{ Metástase } \\
\hline Não & 15 & 100,0 & 13 & 100,0 & \multirow{2}{*}{ NA } & 19 & 100,0 & 7 & 100,0 & NA \\
\hline Sim & 0 & 0,0 & 0 & 0,0 & & 0 & 0,0 & 0 & 0,0 & NA \\
\hline TOTAL & 15 & 100,0 & 13 & 100,0 & & 19 & 100,0 & 7 & 100,0 & \\
\hline
\end{tabular}

$p^{*}$ : valor obtido pelo teste exato de Fisher considerando-se nível de significância de 5\% NA: não se aplica 
APÊNDICE 8 - Distribuição de E-caderina e $\beta$-catenina em relação às características microscópicas dos carcinomas espinocelulares bem diferenciados de boca. Hospital do Câncer, São Paulo, 1970 a 2000

\begin{tabular}{|c|c|c|c|c|c|c|c|c|c|c|}
\hline \multirow{4}{*}{ Variável } & \multicolumn{9}{|c|}{ GRUPO CEC/BD } & \multirow[b]{4}{*}{$p^{*}$} \\
\hline & \multicolumn{4}{|c|}{ E-caderina } & \multicolumn{5}{|c|}{$\beta$-catenina } & \\
\hline & \multicolumn{2}{|c|}{ Fraca } & \multicolumn{2}{|c|}{ Forte } & \multirow[b]{2}{*}{$p^{*}$} & \multicolumn{2}{|c|}{ Fraca } & \multicolumn{2}{|c|}{ Forte } & \\
\hline & $\mathbf{N}$ & $\%$ & $\mathbf{N}$ & $\%$ & & $\mathbf{N}$ & $\%$ & $\mathbf{N}$ & $\%$ & \\
\hline \multicolumn{11}{|l|}{ Queratinização } \\
\hline Alta & 14 & 93,3 & 13 & 100,0 & \multirow{2}{*}{ NA } & 0 & 0,0 & 0 & 0,0 & \multirow{2}{*}{ NA } \\
\hline Baixa & 1 & 6,7 & 0 & 0,0 & & 19 & 100,0 & 7 & 100,0 & \\
\hline \multicolumn{11}{|c|}{ Pleomorfismo nuclear } \\
\hline Baixo & 14 & 93,3 & 13 & 100,0 & \multirow{2}{*}{ NA } & 18 & 94,7 & 7 & 100,0 & \multirow{2}{*}{ NA } \\
\hline Alto & 1 & 6,7 & 0 & 0,0 & & 1 & 5,3 & 0 & 0,0 & \\
\hline \multicolumn{11}{|l|}{ Número de mitoses } \\
\hline Baixo & 14 & 93,3 & 13 & 100,0 & \multirow[t]{2}{*}{ NA } & 18 & 94,7 & 7 & 100,0 & \multirow{2}{*}{ NA } \\
\hline Alto & 1 & 6,7 & 0 & 0,0 & & 1 & 5,3 & 0 & 0,0 & \\
\hline \multicolumn{11}{|l|}{ Padrão de invasão } \\
\hline Compressivo & 4 & 26,7 & 1 & 7,7 & \multirow{2}{*}{0,333} & 4 & 21,1 & 1 & 14,3 & \multirow{2}{*}{0,999} \\
\hline Infiltrativo & 11 & 73,3 & 12 & 92,3 & & 15 & 78,9 & 6 & 85,7 & \\
\hline \multicolumn{11}{|c|}{ Infiltrado inflamatório } \\
\hline Intenso & 13 & 86,7 & 10 & 76,9 & \multirow{2}{*}{0,639} & 15 & 78,9 & 6 & 85,7 & \multirow{2}{*}{0,999} \\
\hline Discreto & 2 & 13,3 & 3 & 23,1 & & 4 & 21,1 & 1 & 14,3 & \\
\hline \multicolumn{11}{|c|}{ Índice de malignidade } \\
\hline Pouco agressivo & 9 & 60,0 & 12 & 92,3 & 0,084 & 14 & 73,7 & 6 & 85,7 & 0.646 \\
\hline Muito agressivo & 6 & 40,0 & 1 & 7,7 & & 5 & 26,3 & 1 & 14,3 & \\
\hline Embolização vasc & & & & & & & & & & \\
\hline Ausente & 9 & 60,0 & 7 & 53,9 & 0,743 & 11 & 57,9 & 4 & 57,1 & 0,999 \\
\hline Presente & 6 & 40,0 & 6 & 46,1 & & 8 & 42,1 & 3 & 42,9 & \\
\hline Infiltração perine & & & & & & & & & & \\
\hline Ausente & 7 & 46,7 & 6 & 46,1 & 0,978 & 9 & 47,4 & 4 & 57,1 & 0.999 \\
\hline Presente & 8 & 53,3 & 7 & 53,9 & 0,910 & 10 & 52,6 & 3 & 42,9 & 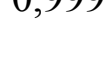 \\
\hline Infiltração mus & & & & & & & & & & \\
\hline Ausente & 4 & 26,7 & 3 & 23,1 & 0,999 & 5 & 26,3 & 2 & 28,6 & 0,999 \\
\hline Presente & 11 & 73,3 & 10 & 76,9 & 0,999 & 14 & 73,7 & 5 & 71,4 & דינד, \\
\hline Infiltração óssea* & & & & & & & & & & \\
\hline Ausente & 5 & 62,5 & 6 & 66,7 & 0.999 & 4 & 33,3 & 2 & 100,0 & $\mathrm{NA}$ \\
\hline Presente & 3 & 37,5 & 3 & 33,3 & & 8 & 66,7 & 0 & 0,0 & \\
\hline TOTAL & 15 & 100,0 & 13 & 100,0 & & 19 & 100,0 & 7 & 100,0 & \\
\hline
\end{tabular}

$p^{*}$ : valor obtido pelo teste exato de Fisher considerando-se nível de significância de 5\% **: excluídos os pacientes com informações ignoradas

NA: não se aplica 